\title{
RECONNAISSANCE INVESTIGATION OF WATER QUALITY, BOTTOM SEDIMENT, AND BIOTA ASSOCIATED WITH IRRIGATION DRAINAGE IN THE MIDDLE ARKANSAS RIVER BASIN, COLORADO AND KANSAS, 1988-89
}

by David K. Mueller, U.S. Geological Survey

Lawrence R. DeWeese, U.S. Fish and Wildlife Service

A. Jack Garner, U.S. Bureau of Reclamation

Timothy B. Spruill, U.S. Geological Survey

U.S. GEOLOGICAL SURVEY

Water-Resources Investigations Report 91-4060

Prepared in cooperation with the

U.S. FISH AND WILDLFE SERVICE and the

U.S. BUREAU OF RECLAMATION

Denver, Colorado

1991 


\section{U.S. DEPARTMENT OF THE INTERIOR}

MANUEL LUJAN, JR., Secretary

U.S. GEOLOGICAL SURVEY

Dallas L. Peck, Director

For additional information write to:

District Chief

U.S. Geological Survey

Box 25046, Mail Stop 415

Federal Center

Denver, CO 80225-0046
Copies of this report can

be purchased from:

U.S. Geological Survey

Books and Open-File Reports Section Box 25425, Mail Stop 517

Federal Center

Denver, CO 80225-0425 


\section{CONTENTS}

Page

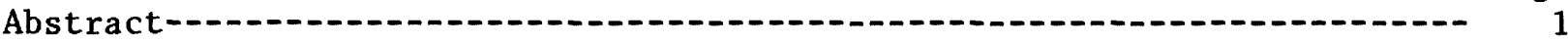

Introduction-

Purpose and scope-- 5

Acknowledgments--

Description of the study area-

Location-

History-

Climate--

Geology--

Soils $-10-0-11$

Land use--

Fish and wildlife-- 13

Hydrologic setting-

Water supply--

Runoff-- 14

Return flows-- 17

Ground water-- 17

Previous studies--

Sample collection and analysis-

Objectives---

Sampling sites-- 22

Sampling methods--

Analytical support--

Discussion of results-

Determination of elevated concentrations-

Water quality- 30

Bottom sediment-- 39

Biota-0.-

Aluminum-

Arsenic-

Cadmi um--

Copper---

Mercury--

Selenium--

Zinc-

Organochlorine pesticides- 47

Correlation among substrates-

Summary--0-0-

References---0-0-0 52

Supplemental data-- 
Figures 1-4. Maps showing:

Page

1. Location of the study area- 6

2. Selected surface-water and political features within the study area- 7

3. Generalized surficial geology of the study area--..-- 10

4. Approximate extent of irrigated land within the

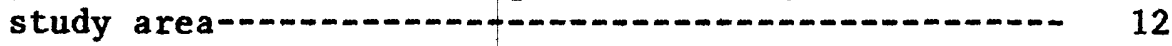

5. Graph showing annual streamflow of the Arkansas River at Portland, Colo., water years 1940-88

6. Graph showing annual streamflow of the Arkansas River below John Martin Reservoir, Colo., water years 1944-88-_-_._- 16

7. Map showing location of sampling sites in the study area-- 23

8. Schematic diagram showing relative orientation of sampling sites and major streams, reservoirs, and canals in the study area-c.

9-11. Graphs showing concentrations of selected constituents in samples from:

9. Stream sites, August 1988 31

10. Reservoir sites, June and October 1988_... 33

11. Ground-water sites, August 1988 34

12. Boxplots of historical specific-conductance data and values measured during the study in 1988-

13. Boxplots of historical dissolved-selenium data and concentrations in water samples collected during the study in 1988 reservoir water samples to concentrations in common carp and gizzard shad at reservoir sites-a

\section{TABLES}

Table 1. Median concentrations of total selenium from historical data collected at water-quality monitoring sites

in the study area-c 18

2. Number of samples collected during the study- 20

3. Constituents analyzed in water, bottom-sediment, and biota samples collected during the study-ar 21

4. Identification of stream, reservoir, and ground-water

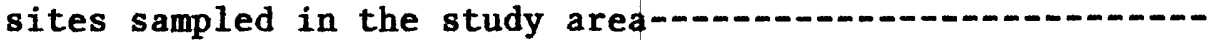

5. Colorado and Kansas water-quality standards and U.S. Environmental Protection Agency criteria for protection of aquatic life-
Colorado and Kansas water-quality standards and U.S. Environmental Protection Agency maximum contaminant levels for domestic water and agricultural supplies------ 
Table 7. Geochemical baselines for selected elements in soils

8. Water-quality data for samples from stream sites in the study area, August 1988-- 57

9. Water-quality data for samples from reservoir sites in the study area, June 1988- 58

10. Water-quality data for samples from reservoir sites in the study area, October 1988-59

11. Water-quality data for samples from ground-water sites in the study area, August 1988

12. Chemical data for bottom-sediment samples from stream sites in the study area, August 1988-

13. Chemical data for bottom-sediment samples collected at reservoir sites in the study area, October 1988----race-element concentrations in adult livers from individuals or composite samples of waterbirds collected at reservoir sites in the study area, June 7-10, 1988-.-.-

15. Trace-element concentrations in adult livers and breast muscles from individual samples of waterbirds collected at reservoir sites in the study area, October 7-13, 1988--

16. Trace-element concentrations in individuals or composite samples of livers and whole bodies of juveniles, whole nestlings and eggs of waterbirds and passerines collected at reservoir sites in the study area, June 7-10, 1988-.....

17. Trace-element concentrations in composite samples of fish species and crayfish collected at selected stream sites in the study area, August 8-10, 1988-

18. Trace-element concentrations in individual and composite samples of whole fish and invertebrates collected at reservoir sites in the study area, June 7-10 and October 7-13, 1988---

19. Trace-element concentrations in composite samples of aquatic plant species collected at selected reservoir sites in the study area, June 7-10, 1988-

20. Concentrations of organochlorine pesticides in livers and eggs of birds and composite samples of fish collected at selected reservoir sites in the study area, June 7-10, 1988-1 
Multiply

acre

acre-foot (acre-ft)

cubic foot per second $\left(\mathrm{ft}^{3} / \mathrm{s}\right)$

foot $(\mathrm{ft})$

foot per mile $(\mathrm{ft} / \mathrm{mi})$

inch (in.)

inch per year (in/yr)

micrometer $(\mu \mathrm{m})$

mile (mi)

millimeter $(\mathrm{mm})$

square mile $\left(\mathrm{mi}^{2}\right)$
By

$$
0.4047
$$

1,233

0.028317

0.3048

0.3048

25.4

25.4

0.00003937

1.609

0.03937

2.59
To obtain

hectare

cubic meter

cubic meter per second meter

meter per kilometer

millimeter

millimeter per annum

inch

kilometer

inch

square kilometer

Temperature in degree Fahrenheit $\left({ }^{\circ} \mathrm{F}\right)$ can be converted to degree Celsius $\left({ }^{\circ} \mathrm{C}\right)$ as follows:

$$
{ }^{\circ} \mathrm{C}=5 / 9\left({ }^{\circ} \mathrm{F}-32\right) \text {. }
$$

Temperature in degree Celsius $\left({ }^{\circ} \mathrm{C}\right)$ can be converted to degree Fahrenheit $\left({ }^{\circ} \mathrm{F}\right)$ as follows:

$$
{ }^{\circ} \mathrm{F}=9 / 5\left({ }^{\circ} \mathrm{C}\right)+32 \text {. }
$$

Abbreviated water-quality units used in this report:

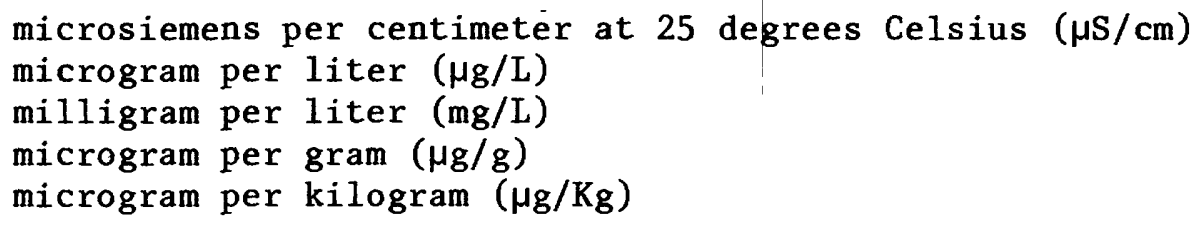

Dry-weight concentrations in biota samples may be converted to wet-weight concentrations as follows:

Wet-weight concentration $=[1-($ percent moisture/100) $]$ Dry-weight concentration . 
RECONNAISSANCE INVESTIGATION OF WATER QUALITY, BOTTOM SEDIMENT, AND BIOTA ASSOCIATED WITH IRRIGATION DRAINAGE IN THE MIDDLE ARKANSAS RIVER BASIN, COLORADO AND KANSAS, 1988-89

David K. Mueller, Lawrence R. DeWeese, A. Jack Garner, and Timothy B. Spruill

\section{ABSTRACT}

During the last several years, concern by the U.S. Department of the Interior has been increasing about the potential effects of irrigation drainage on the health of humans, fish, and wildlife. During 1988, a reconnaissance investigation was made of irrigation-drainage quality in the middle Arkansas River basin in southeastern Colorado and southwestern Kansas. This area was selected because high concentrations of selenium previously had been detected at several sites on the Arkansas River and its tributaries. This investigation was part of a program initiated in 1985 by the U.S. Department of the Interior to evaluate the effects of irrigation drainage on water quality, bottom sediment, and biota in the Western United States.

Water, bottom-sediment, and biota samples were collected at 14 surfacewater sites- -7 sites on the Arkansas River, 2 sites on tributary streams, and 5 sites on reservoirs. Ground-water samples were collected from five municipal wells completed in the Arkansas River valley alluvial aquifer.

Drainage from irrigated land underlain by marine shale affects the Arkansas River between La Junta, Colo., and Deerfield, Kans.; two tributary streams in the vicinity of Pueblo, Colo.; and several off-channel reservoirs. Selenium was the only trace constituent associated with irrigation drainage that was detected at elevated concentrations in water, bottom sediment, and biota.

Selenium concentrations in surface water ranged from 1 microgram per liter, in Pueblo Reservoir near the upstream end of the study area in Colorado, to 52 micrograms per liter in the St. Charles River near Vineland, Colo. The maximum concentration detected in alluvial ground water was 29 micrograms per liter at Las Animas, Colo. State drinking-water standards and the U.S. Environmental Protection Agency maximum contaminant level for selenium (10 micrograms per liter) were exceeded at three streams sites and three ground-water sites. State aquatic-life standards and the U.S. Environmental Protection Agency criterion for acute exposure to selenium were not exceeded at any sites on the Arkansas River or in any reservoirs. However, the Colorado standard for chronic exposure and the U.S. Environmental Protection Agency criterion for chronic and acute exposure were exceeded in two tributary streams. The U.S. Environmental Protection Agency criterion for chronic exposure was exceeded at four sites on the Arkansas River and in three reservoirs. 
Elevated concentrations of selenium in bottom sediment occurred at four of five reservoir sites and at one tributary site. The maximum concentration was 5.4 micrograms per gram in Lake Meredith near Ordway, Colo.

Geometric mean selenium concentrations in livers from bird species collected at reservoirs during the spring were highest in killdeer ( 9.9 to 42 micrograms per gram dry weight), intermediate in mallards (9.7 to 24 micrograms per gram), and lowest in American coots (12 to 15 micrograms per gram). The maximum selenium concentration ( 56 micrograms per gram) was detected in the liver of a black-necked stilt from Lake Meredith in Colorado.

Five species of fish from the Arkansas River had selenium concentrations ranging from 2.1 to 18.5 micrograms per gram dry weight, and three species from the tributaries had selenium concentrations ranging from 3.6 to $16.9 \mathrm{micro-}$ grams per gram. Thirteen species of fish in the reservoirs had selenium concentrations ranging from 2.2 to 20 micrograms per gram. Selenium concentrations in invertebrates from the Arkansas River, tributaries, and reservoirs ranged from 2.7 to 8.7 micrograms per gram. The maximum concentration of selenium detected in plants was 14 micrograms per gram in a sample of algae from Lake Meredith in Colorado. Eight organochlorine pesticides were detected in some samples of bird livers and eggs and in fish from the reservoirs, but all concentrations were within the ranges of reported background concentrations. No evidence of deformity or reproductive failure was observed for any bird or fish species; however, the study was not designed to assess reproduction or to determine the extent of embryonic deformities.

Selenium concentrations in some samples of food organisms (small fish, invertebrates, and aquatic plants) exceeded the dietary concentration of 10 micrograms per gram wet weight demonstrated to alter reproduction in mallards. Nearly all fish samples had selenium concentrations exceeding the 85 th percentile established by a national survey. Nearly all fish samples from three reservoirs and almost none from two other reservoirs had whole-fish concentrations of selenium exceeding the concentration that correlated with reproductive impairment in bluegills.

Selenium concentrations in fish collected from reservoir sites were positively correlated to selenium concentrations in the reservoir water. No other relations between abiotic and biotic matrices were identified.

Elevated concentrations of aluminum, arsenic, copper, lead, mercury, and zinc also were determined in at least one matrix (water, sediment, or biota) at one or more sites. The source of lead, mercury, and zinc may be mine drainage upstream from the study area. 


\section{INTRODUCTION}

During the last several years, there has been increasing concern about the quality of irrigation drainage and its potentially harmful effects on human health, fish, and wildlife. Concentrations of selenium greater than the water-quality criterion $(35 \mu \mathrm{g} / \mathrm{L})$ for the protection of aquatic life (U.S. Environmental Protection Agency, 1986) have been detected in subsurface drainage from irrigated land in the western part of the San Joaquin Valley in California. In 1983, incidences of mortality, birth defects, and reproductive failures in waterfowl were discovered by the U.S. Fish and Wildlife Service at the Kesterson National Wildlife Refuge in the western San Joaquin Valley, where irrigation drainage was impounded. In addition, potentially toxic trace elements and pesticide residues have been detected in other areas in Western States that receive irrigation drainage.

Because of concerns expressed by the U.S. Congress, the U.S. Department of the Interior (DOI) started a program in late 1985 to identify the nature and extent of irrigation-induced water-quality problems that might exist in Western States. In October 1985, an interbureau group known as the "Task Group on Irrigation Drainage" was formed within the DOI. The Task Group subsequently prepared a comprehensive plan for reviewing irrigation-drainage concerns for which the DOI may have responsibility.

The DOI developed a management strategy, and the Task Group prepared a comprehensive plan for reviewing irrigation-drainage concerns. Initially, the Task Group identified 20 locations in 13 States that warranted reconnaissancelevel field investigations. These locations relate to three specific areas of DOI responsibilities: (1) Irrigation or drainage facilities constructed or managed by the DOI, (2) national wildlife refuges managed by the DOI, and (3) other migratory-bird or endangered-species management areas that receive water from DOI-funded projects.

Nine of the 20 locations were selected for reconnaissance investigations during 1986-87. The nine areas were:

Arizona-California: Lower Colorado-Gila River Valley area

California:

Salton Sea area

Tulare Lake area

Montana :

Sun River Reclamation Project area

Milk River Reclamation Project area

Nevada:

Stillwater Wildlife Management area

Texas:

Lower Rio Grande-Laguna Atascosa National

Wildlife Refuge area

Utah:

Middle Green River basin area

Wyoming:

Kendrick Reclamation Project area 
In 1988, reports for seven of the reconnaissance investigations were published. Reports for the remaining two areas were published in 1990. Based on results of the first nine reconnaissance investigations, four detailed studies were initiated in 1988: Salton Sea area, Stillwater Wildlife Management area, middle Green River basin area, and Kendrick Reclamation Project area. Eleven more reconnaissance investigations were initiated in 1988:

\author{
California: \\ California-Oregon: \\ Colorado: \\ Colorado-Kansas : \\ Idaho: \\ New Mexico: \\ Oregon:
}

South Dakota:

Wyoming:

\author{
Sacramento Refuge Complex \\ Klamath Basin Refuge Complex \\ Gunnison and Uncompahgre River basins and \\ Sweitzer Lake \\ Pine River Project
}

Middle Arkansas River basin

American Falls Reservoir

Middle Rio Grande Project and Bosque del Apache National Wildlife Refuge

Malheur National Wildlife Refuge

Angostura Reclamation Unit

Belle Fourche Reclamation Project

Riverton Reclamation Project

All studies were conducted by interbureau field teams composed of a scientist from the U.S. Geological Survey as team leader, with additional U.S. Geological Survey, U.S. Fish and Wildlife Service, and U.S. Bureau of Reclamation scientists representing several different disciplines. The reconnaissance investigations were directed toward determining whether irrigation drainage: (1) has caused or has the potential to cause significant harmful effects on human health, fish, and wildlife, or (2) may adversely affect the suitability of water for other beneficial uses.

The middle Arkansas River basin was selected for study primarily because historical records indicated the occurrence of high concentrations of selenium in surface water in the basin. Selenium is a primary element of concern in drainage from irrigated land. The median selenium concentration from 1975 through 1987 in the Arkansas River near Coolidge, Kans., was $19 \mu \mathrm{g} / \mathrm{L}$, the highest of any site in the U.S. Geological Survey National Stream Quality Accounting Network (NASQAN). Concentrations of selenium greater than the State drinking water standard $(10 \mu \mathrm{g} / \mathrm{L})$ have been detected at several other sites on the Arkansas River and its tributaries in the study area. The Fryingpan-Arkansas project, constructed and operated by the U.S. Bureau of Reclamation, provides a supplemental water supply to irrigators in the study area. Although there are no U.S. Fish and Wildlife Service refuges in the study area, it is used intensively by migratory waterbirds, and several Stateoperated wildlife areas are located in the study area. 
This report presents background information about the middle Arkansas River basin and describes the results of a reconnaissance investigation of water quality, bottom sediment, and biota associated with irrigation drainage in the basin. The results of the investigation are intended for use by the DOI in determining if irrigation drainage has caused or has the potential to cause harmful effects on human health, fish, and wildlife, or might impair the suitability of water for other beneficial uses.

Water and bottom-sediment samples were collected by personnel of the U.S. Geological Survey. Samples were collected at 14 surface-water and 5 ground-water sites in the basin from near Pueblo, Colo., to near Garden City, Kans. Sites included streams, reservoirs, and municipal wells. Biota samples were collected by personnel of the U.S. Fish and Wildlife Service, assisted by the Colorado Division of Wildlife and the Kansas Department of Parks and Wildlife. Samples were collected at the same 14 surface-water sites where water and bottom-sediment samples were collected. All sampling was completed during June through October 1988.

\section{Acknowledgments}

The authors wish to thank the many people and agencies who assisted in sample collection during the study. Charles Bennett and Jim Melby, of the Colorado Division of Wildlife, helped collect fish at reservoir sites in Colorado, and Terry Sexson, of the Kansas Department of Parks and Wildlife, helped collect birds at Lake McKinney in Kansas. Steve Lasero, Bryant Will, Mark Leslie, and Steve Keffer, of the Colorado Division of Wildlife, and Bruce Peters, of the Kansas Department of Parks and Wildlife, arranged permission for bird and fish collection in their jurisdictions. Harold Scofield, of the city of La Junta, and Dale Kortz, of the city of Las Animas, in Colorado, and John Armstrong, of the city of Syracuse, Louis Vanover, of the city of Lakin, and Wayne West, of the city of Deerfield, in Kansas, provided access to their municipal wells and assistance with sample collection. W. Fred Stoeckly, of the Garden City Company, which owns and operates Lake McKinney, gave permission to sample that site. Kurt Bontrigger and Erwin Caldwell, who own land near Deerfield, provided access for sampling the Arkansas River at the last major diversion point in the study area.

\section{DESCRIPTION OF THE STUDY AREA}

\section{Location}

The study area comprises parts of the Arkansas River basin in southeastern Colorado and southwestern Kansas (fig. 1). It extends along the Arkansas River from the foothills of the Rocky Mountains near Pueblo to Garden City, a distance of about $250 \mathrm{mi}$ (fig. 2). 


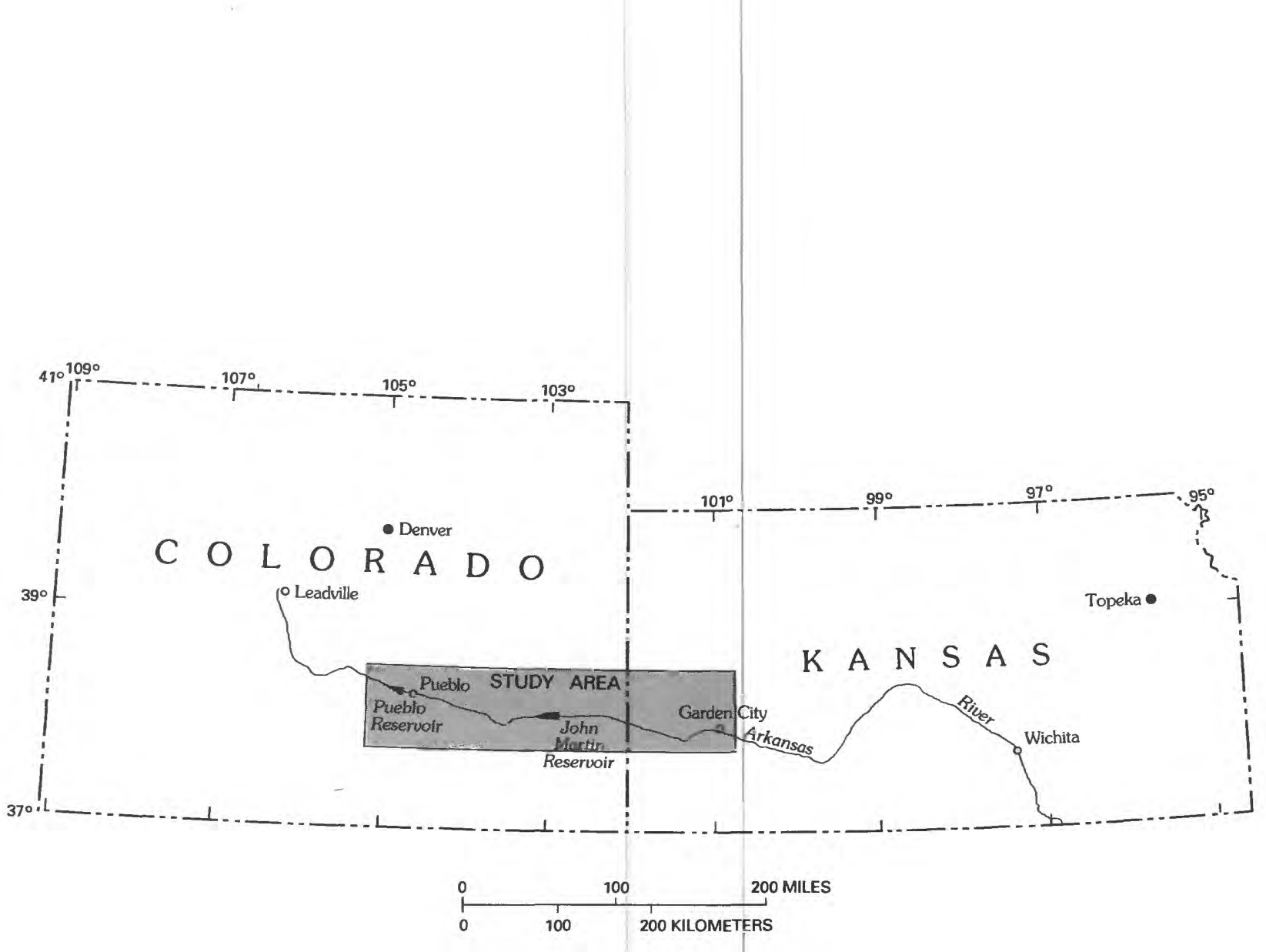

Figure 1.--Location of the study area.

The Arkansas River originates to the northwest of the study area near Leadville, Colo. The river flows south and east through mountainous terrain, emerging from the mountains west of Pueblo at an altitude of about 5,000 $\mathrm{ft}$. At Pueblo, the river is impounded to form Pueblo Reservoir, near the western boundary of the study area.

From Pueblo, the Arkansas River flows eastward across Colorado, passing through flat terraces and nearly level flood plains. Along the way, a number of perennial and intermittent tributaries that drain areas to the north and south flow into the river. Headwaters of all the perennial tributaries are in the mountains. The Arkansas River and its tributaries drain an area of 25,410 $\mathrm{mi}^{2}$ in Colorado, including 4,669 $\mathrm{mi}^{2}$ upstream from Pueblo Reservoir.

The Arkansas River enters Kansas at an altitude of 3,350 ft and continues to flow eastward for about $60 \mathrm{mi}$ to Garden City (altitude 2,950 ft) near the eastern boundary of the study area. The drainage area of the Arkansas River between the Colorado-Kansas State line and Garden City is about 3,000 $\mathrm{mi}^{2}$. 

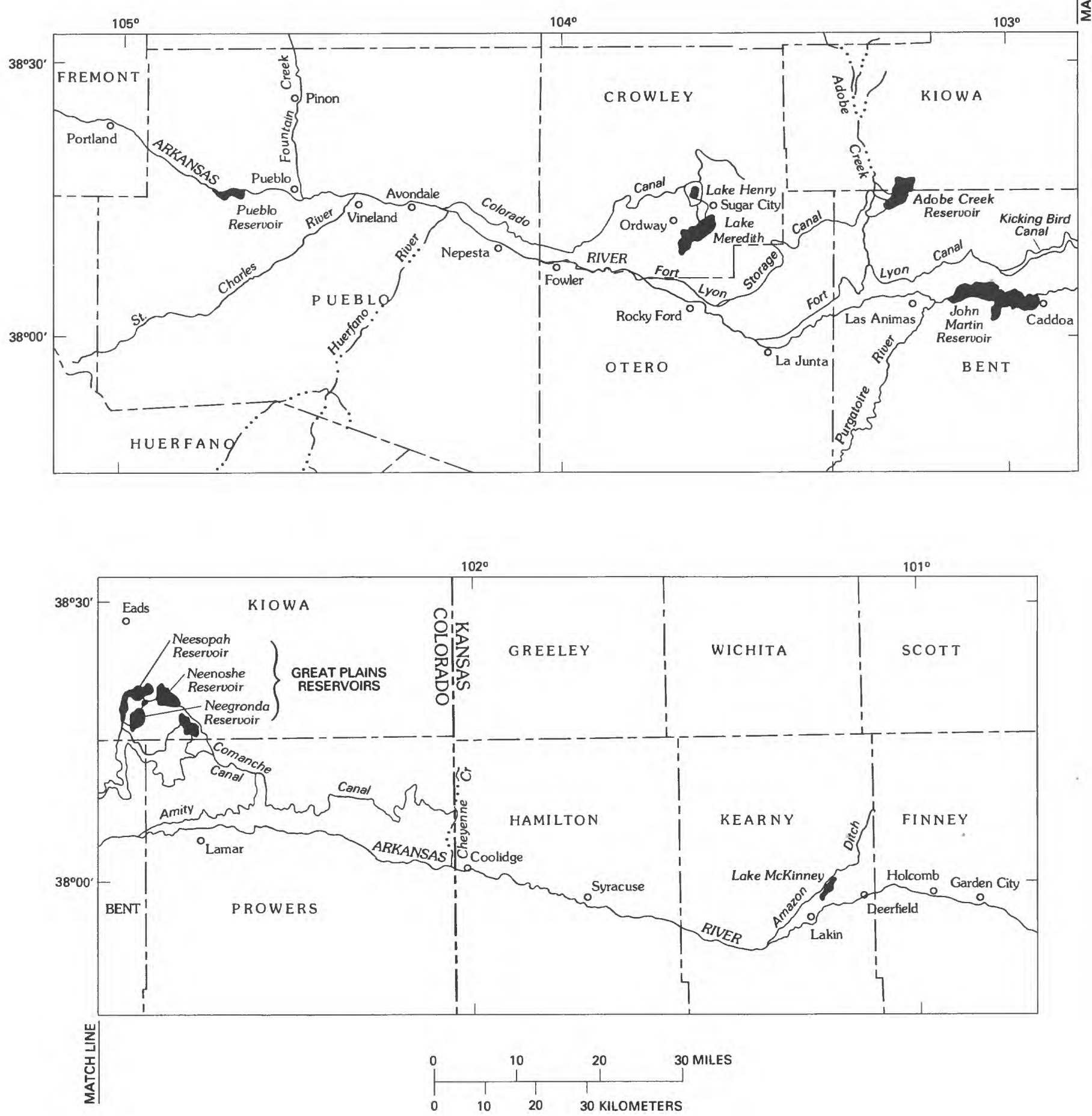

Figure 2.--Selected surface-water and political features within the study area. 


\section{History}

The settlement of the Arkansas River basin in Colorado and Kansas followed the usual frontier pattern. First came the explorers, then the trappers and traders, next the herdsmen, and finally, the permanent agricultural settlers. The number and size of settlements in the region grew after the Pikes Peak gold rush in the late $1850^{\prime} \mathrm{s}$, which increased the demand for agricultural production. Thus began the era of irrigated agriculture in the Arkansas River valley and the allocation of the water resources in the basin.

In Colorado, the earliest priority for a water right in the basin was recorded in the spring of 1859 . During the $1860^{\circ} \mathrm{s}$, priorities were established and diversion ditches were constructed in the headwater areas; however, it was not until 1874, in the vicinity of Rocky Ford, Colo., that large-scale irrigation began. Major appropriattions of streamflow were developed between 1880 and 1910 , creating a need for storage reservoirs. Consequently, irrigation companies began building off-channel reservoirs to store winter and early spring runoff for later use.

In Kansas, during the early $1880^{\prime}$ s, several irrigation canals were constructed to divert water from the Arkansas River; however, expansion of surface-water irrigation in Kansas was hindered because diversions in eastern Colorado made streamflow insufficient and unreliable for extensive irrigation development. In the late $1880^{\prime} \mathrm{s}$, farmers began using windmills to pump ground water for irrigation. In 1908, centrifugal pumps were introduced, and the area irrigated by ground water gradually was increased.

The irrigation water supply in the Arkansas River valley has always been subject to large annual and seasonal fluctuations. To regulate these fluctuations, a number of irrigation companies have constructed off-channel reservoirs to store winter and early spring flows for later productive use. During 1880 through 1910, storage rights were established to permit the yearly diversion of almost 500,000 acre-ft of Arkansas River water to off-channel reservoirs. In 1943, the U.S. Army Corps of Engineers completed construction of the John Martin Reservoir in Colorado on the Arkansas River east of Las Animas; and in 1975, the U.S. Bureau of Reclamation completed construction of Pueblo Reservoir on the Arkansas River west of Pueblo, Colo. These two reservoirs, which have a combined storage capacity of about 1 million acre-ft, are multiuse facilities that provide benefits such as flood control, irrigation, wildlife enhancement, and recreation.

Water development in the basin was not restricted to agricultural purposes. Municipal and industrial water users established decrees and developed diversion and storage systems of their own to supply potable water. As communities increased in population and as agriculture expanded in the $1920^{\prime} \mathrm{s}$, ditch companies and municipalities began to consider the Colorado River basin, west of the Continental Divide, as a source of unallocated water. By 1935, seven projects had been constructed to import water into the Arkansas River basin. In 1971, the U.S. Bureau of Reclamation completed the Boustead Tunnel in Colorado, a facility of the Fryingpan-Arkansas Project. Since then, the project has imported an average of about 44,000 acre-ft of water per year from the Colorado River basin into the Arkansas River basin near Leadville. The project is designed to import a long-term average of about 69,000 acre-ft per year. 
The semiarid climate of the study area is characterized by low to moderate precipitation, substantial evaporation, low humidity, moderate to intense winds, and a large daily range in temperature. At Pueblo, the mean annual temperature is $52.7^{\circ} \mathrm{F}$, the mean January temperature is $30.0^{\circ} \mathrm{F}$, and the mean July temperature is $76.5^{\circ} \mathrm{F}$. About $250 \mathrm{mi}$ to the east at Garden City, the mean annual temperature is $54.7^{\circ} \mathrm{F}$, the mean January temperature is $25.1{ }^{\circ} \mathrm{F}$, and the mean July temperature is $79.0^{\circ} \mathrm{F}$. The average time between killing frosts ranges from 173 days at Pueblo to 184 days at Garden City. The last killing frost generally occurs in late April, and the first killing frost generally occurs in mid-October.

Mean annual precipitation ranges from 11.8 in. at Pueblo to 17.5 in. at Garden City. About 75 to 80 percent of the annual precipitation falls as rain during the growing season. Throughout the area, potential evapotranspiration greatly exceeds precipitation. Mean pan evaporation during April-0ctober is about 60 in. near Pueblo and increases to about 67 in. at John Martin Reservoir and about 77 in. at Garden City (Farnsworth and Thompson, 1982).

\section{Geology}

The headwaters of the Arkansas River are in an area of mineralized igneous and metamorphic bedrock around Leadville. Drainage from active and abandoned mines in this area contains a variety of trace elements, particularly cadmium, copper, iron, manganese, and zinc '(Kimball and Wetherbee, 1989).

Cretaceous marine shales and limestones are exposed extensively within the study area (fig. 3). Outcrops of the Pierre Shale are common in the Fountain Creek basin in Colorado, north of Pueblo. The Niobrara Formation (shale and limestone) is exposed north of the Arkansas River from the vicinity of Fowler, Colo., east to the State line. The Niobrara Formation and the Carlile Shale are exposed south of the river from Pueblo Reservoir to La Junta. In the Kansas part of the study area, the Graneros Shale and Greenhorn Limestone are exposed along the north edge of the Arkansas River valley.

The Tertiary Ogallala Formation (loose to well-cemented sand and gravel) outcrops extensively in the eastern part of the study area. Other formations exposed at the surface include Cretaceous sandstones; Jurassic, Permian, and Pennsylvanian sedimentary rocks; and Precambrian igneous rocks.

In shale and limestone, concentrations of many elements, particularly arsenic, boron, selenium, and sulfur can be enriched relative to concentrations in other rock types (Turekian and Wedepohl, 1961). In the Pierre Shale, arsenic, cadmium, molybdenum, selenium, and uranium are highly concentrated (Schultz and others, 1980). Elevated selenium concentrations also are present in the Niobrara Formation near the study area (Hatten, 1969). 

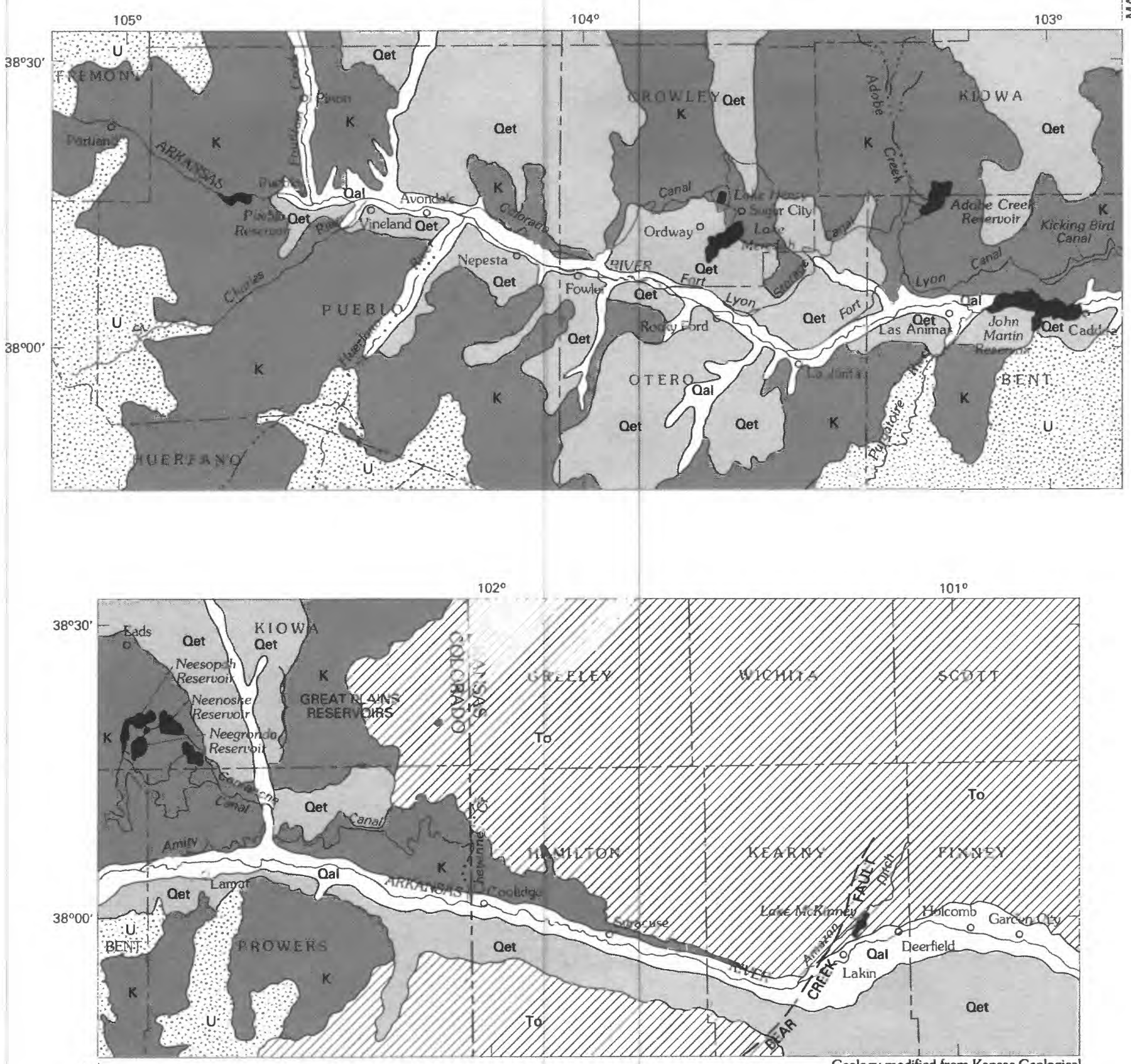

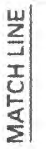

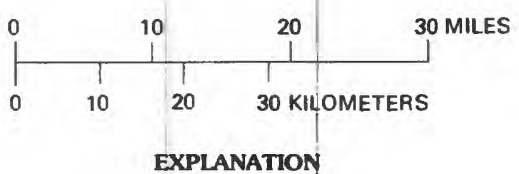

Geology modified from Kansas Geological Geology modified from Kansas
Survey (1964) and Tweto (1979)

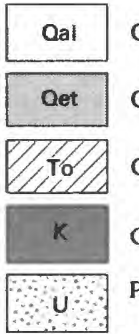

QUATERNARY ALLUIUM

QUATERNARY EOLIAN AND TERRACE DEPOSTTES

OGALLALA FORMATION

CRETACEOUS MARINE SHALES AND LIMESTONES

PRECAMBRIAN, PERMIAN/PENNSYLVANIAN, JURASIC OR

CRETACEOUS-Undifferentiated

Figure 3.--Generalized surficial geology of the study area. 
West of Lakin, Kans., alluvium fills a trough cut into the bedrock of Cretaceous age. The alluvium consists of fairly well sorted sand and gravel with minor amounts of clay. Thickness of the alluvium ranges from about 0 to about $300 \mathrm{ft}$; the maximum thickness is in Colorado. Near Lakin, the alluvial trough is transected by the Bear Creek fault (fig. 3). This fault may have been caused by a structural collapse of the overlying rock strata when salt in underlying evaporite deposits was dissolved and removed by ground water (Barker and others, 1983). As a result, the trough downstream from the fault zone is filled with unconsolidated material to a depth of about $200 \mathrm{ft}$.

South of the Arkansas River in Kansas, sand dunes of Pleistocene age have been deposited. The sand is unsaturated and is stabilized by deep-rooted vegetation.

\section{$\underline{\text { Soils }}$}

Soils in the study area have originated from residual-bedrock, alluvial, and eolian sources. Most soils in the study area range from clayey loams to sandy loams. These soils generally have a high infiltration capacity that results in rapid percolation of applied irrigation water to the shallow ground water. The soils have developed under conditions of low precipitation (less than $20 \mathrm{in} / \mathrm{yr}$ ) and high potential evapotranspiration (greater than $60 \mathrm{in} / \mathrm{yr}$ ), which could result in accumulation of selenium and other trace elements leached from the parent material. Lime (calcium carbonate) is abundant in the soils; the zone of maximum accumulation usually is between depths of 18 to 36 in.

Soils on uplands in the western part of the study area, between Pueblo and Las Animas, are formed from residual bedrock. On the south side of the Arkansas River, upland soils are derived from a soft, sandy shale. On the north side of the river, in the vicinity of Ordway and Sugar City, Colo., upland soils are derived from a soft, sandy, gypsiferous shale. Soils derived from old alluvial sediments on uplands and terraces are widely distributed in the Colorado part of the study area.

Soils on flood plains and in the lowest topographic positions adjacent to the Arkansas River and tributary streams are derived from recent alluvial sediments. In Kansas, deposits of gypsum have been identified in flood-plain soils (McBee and others, 1961), indicating that the source of the alluvium might be gypsiferous formations of Cretaceous age that crop out along the north edge of the valley. These soils are saline and have been affected by flooding, irrigation, and a shallow water table (Gutentag and others, 1981). Sand dunes of eolian origin are located south of the Arkansas River in Kansas. East of Lakin, well-drained eolian soils also are present north of the river.

\section{Land Use}

Land use in the Arkansas River valley is predominantly agricultural, consisting of about 50 percent rangeland and non-cropped area and about 50 percent cropland. Major crops are alfalfa, grain sorgum, corn, and wheat. Approximately 700,000 acres were irrigated in the study area during 1980 . Most of the irrigated land is in the alluvial valley of the Arkansas River, along the major tributary streams, and near off-channel reservoirs (fig. 4). 


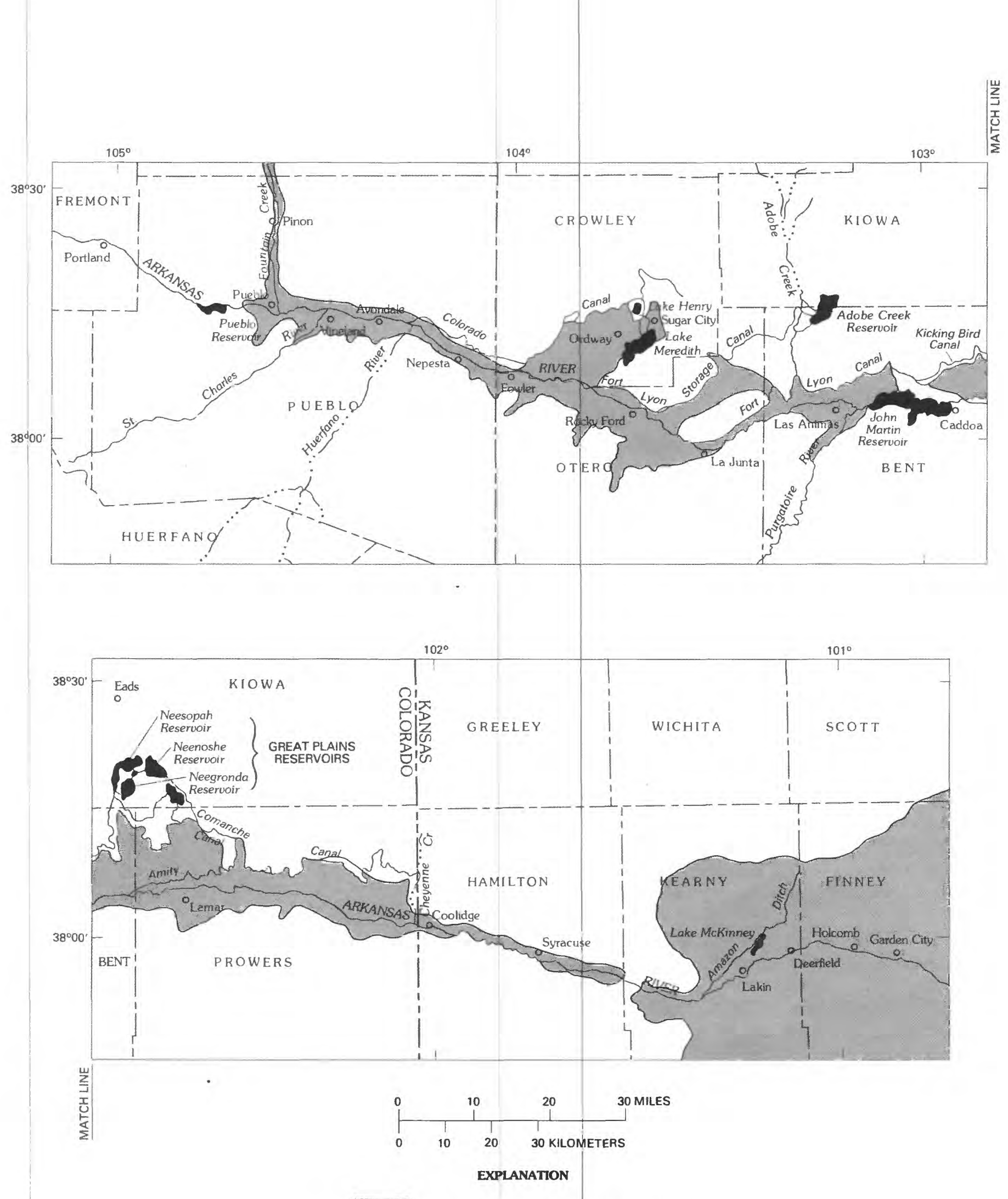

APPROXIMATE EXTENT OF IRRIGATED LAND

Figure 4.--Approximate extent of irrigated land within the study area. 
The reservoirs in the study area are large bodies of water in an otherwise dry region; therefore, they are valuable not only for recreational use, but for fish and wildlife habitat as well. Several reservoirs in the study area are managed by the State of Colorado for sport fishing and waterfowl hunting. Pueblo and John Martin Reservoirs (fig. 2) support large populations of bass, crappie, and walleye. The State manages these reservoirs by intensively monitoring the fish populations and by restocking various species as needed. The warm-water sport fisheries in these reservoirs are highly regarded by sportsmen from Colorado and neighboring States. Lake McKinney, the only sizeable reservoir in the Kansas part of the study area, is privately owned, and managed solely for irrigation-water supply.

Many reservoirs in the study area provide breeding and stopover habitat for migratory birds. Flooded trees at the upper ends of Pueblo and John Martin Reservoirs are used for nesting by fish-eating birds, including double-crested cormorants and great blue herons. Ospreys nest near Pueblo Reservoir. The abundance of gizzard shad in the reservoirs attracts these birds and is probably responsible for maintaining their populations. The inlet area of John Martin Reservoir and the southwest shore of Lake Meredith in Colorado have extensive cattail marsh habitat. This habitat is occupied during the summer by nesting ducks, American coots, black-crowned night herons, other species of waterbirds, and blackbirds. Lake McKinney in Kansas is used by ducks during the autumn migration, and the limited cattail marsh habitat at Lake McKinney supports a few nesting waterbirds, mainly American coots. The Great Plains Reservoirs in Colorado provide little breeding habitat but are an important stopover area for migratory waterbirds.

Nests of two federally endangered species have been found in the study area in Colorado: The interior least tern at Adobe Creek Reservoir and the piping plover at Neenoshe Reservoir, one of the Great Plains Reservoirs. A thorough survey of breeding birds and their foraging sites has not been completed for the entire study area, but these species may use other reservoirs at various times of the year. Historical records indicate least terns and piping plovers have used Adobe Creek Reservoir, the Great Plains Reservoirs, Lake Henry, and Lake Meredith. Bald eagles (a federally endangered species) have been observed at reservoirs and along the Arkansas River in the study area during migration. Other species of Federal concern that use aquatic habitats in the study area are the Arkansas darter (may be recommended for threatened status) and the snowy plover (candidate species for threatened or endangered status).

\section{HYDROLOGIC SETTING}

\section{Water Supply}

The surface-water supply system in the study area is a complex network of natural channels, canals, and on- and off-channel reservoirs. Private irrigation systems include 16 major and several minor canals in Colorado and 5 canals in Kansas. These canals divert water directly from the Arkansas River, generally for direct application; however, several of the canals divert water for storage in privately owned, off-channel reservoirs. 
Pueblo Reservoir, near the upstream end of the study area, provides regulation of floodflows and storage of water for municipal and irrigation uses. It has a total capacity of about 358,000 acre-ft. During 1988 , the storage volume ranged from a maximum of about 267,000 acre-ft in March to a minimum of about 149,000 acre-ft in October (U.S. Geological Survey, 1989 and 1990).

As part of the U.S. Bureau of Reclamation's Fryingpan-Arkansas project, Pueblo Reservoir provides supplemental irrigation water to 9 major and 2 minor, privately operated irrigation systems in the Southeastern Colorado Water Conservancy District. Collectively, these systems irrigate 240,000 acres and have an annual headgate diversion requirement of about 810,000 acre-ft. These systems had existed in the study area for about 100 years before receiving their first project water in 1978. Since 1978, annual water deliveries from the project have averaged about 23,000 acre- $\mathrm{ft}$, or 2.8 percent of the required headgate diversions.

In 1943, the U.S. Army Corps of Engineers began operating John Martin Reservoir to regulate floodflows and to apportion water in the Arkansas River between Colorado and Kansas according to guidelines of the Arkansas River Compact. In recent years, the reservoir also has been used to regulate irrigation-water supplies. John Martin Reservoir has a total capacity of 615,000 acre-ft, of which about 270,000 acre-ft is reserved for flood control. During 1988, the storage volume ranged from a maximum of 310,000 acre-ft in April to a minimum of 79,000 acre-ft in October (U.S. Geological Survey, 1989 and 1990).

To supplement surface-water supplies, the alluvial aquifer, which is hydraulically connected to the Arkansas River, has been extensively developed. By the early 1970's, approximately 1,400 irrigation wells had been developed in the alluvial aquifer in Colorado (Taylor and Luckey, 1974), and by the early $1980^{\prime} \mathrm{s}$, about 450 irrigation wells had been developed in the alluvial aquifer in Kansas (Barker and others, 1983; Dunlap and others, 1985). The aquifer also is used for municipal supplies. The towns that use water from the alluvial aquifer either as a primary or a supplemental supply are Rocky Ford, La Junta, and Las Animas in Colorado, and Syracuse, Lakin, Deerfield, and Holcomb in Kansas.

\section{Runoff}

The primary source of streamflow in the Arkansas River basin is the snowpack that accumulates in high-altitude headwater areas during the winter months. Inflow to Pueblo Reservoir, near the western boundary of the study area, can be approximated by streamflow measured at Portland, Colo. Annual streamflow at this site for water years (October through September) 1940-88 is plotted in figure 5. From 1983 through 1987, streamflow was much greater than the mean. During this period, reservoirs remained full, and releases were greater than normal. Runoff was less than normal during the year that samples were collected for this study (1988), but the hydrology and water quality within the study area were still affected by the large accumulation of runoff from the 5 previous years. 


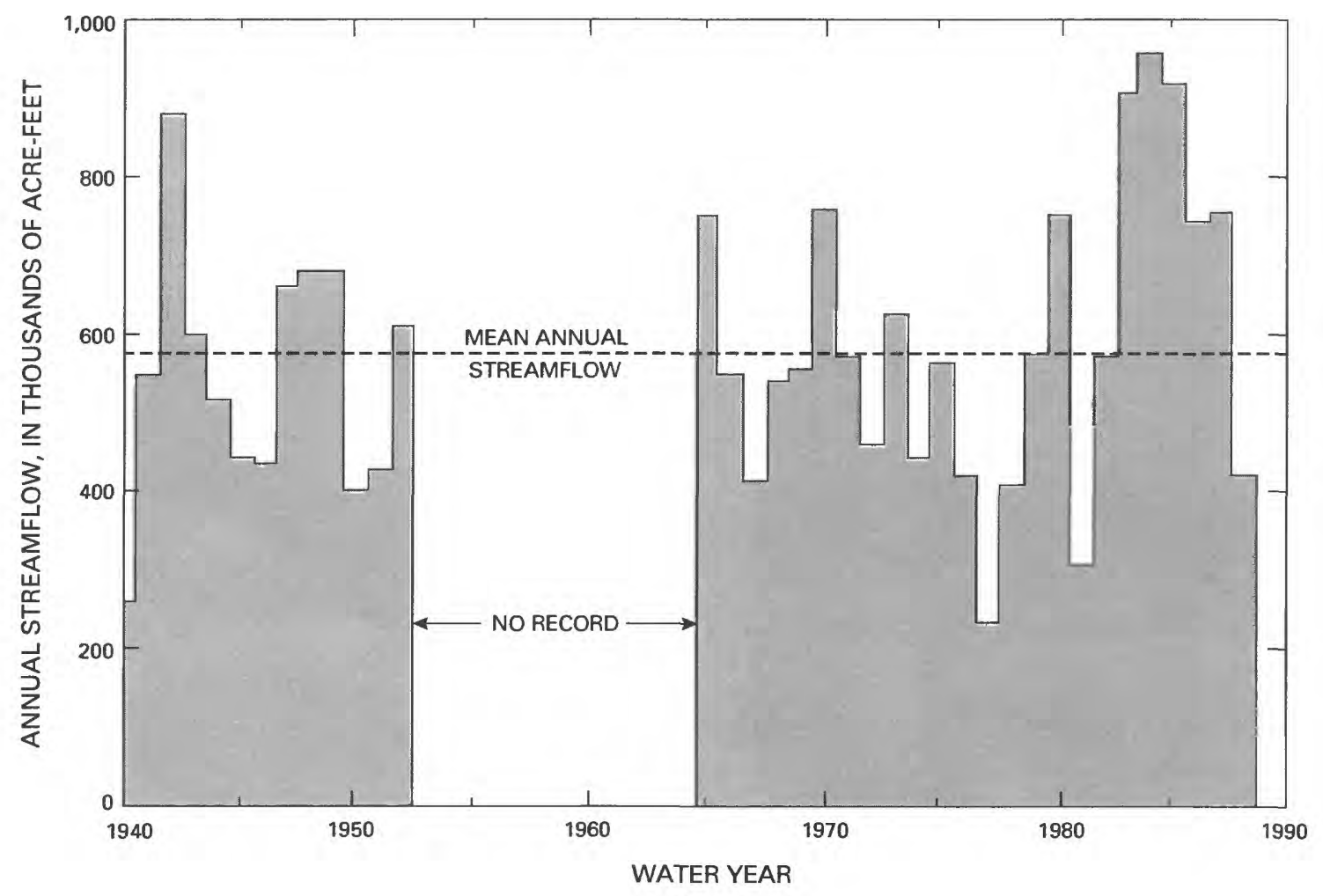

Figure 5.--Annual streamflow of the Arkansas River at Portland, Colo., water years 1940-88 (drainage area 434 square miles).

At Pueblo, the flow of the Arkansas River is regulated by releases from Pueblo Reservoir. Mean annual streamflow is about 515,000 acre-ft. Eighty percent of this flow occurs during the April-October irrigation season. The low flows of the river at Pueblo occur during February and March when winter storage accumulates in the reservoir.

Perennial tributaries in the western part of the study area are sustained by the mountain snowpack. Most tributaries of the Arkansas River downstream from the Saint Charles River originate on the plains, east of the mountains, and flows are ephemeral. There are no perennial or significant ephemeral tributaries to the Arkansas River in the Kansas part of the study area. 
Streamflow in the Arkansas River in the eastern part of the study area has been regulated by John Martin Reservoir since 1943. The historical maximum storage (about 430,000 acre-ft) in the reservoir occurred in 1965 . During water years 1965-73, annual release from the reservoir averaged about 200,000 acre-ft (fig. 6). During water years 1974-78, the mean annual release decreased to 92,700 acre-ft, and the reservoir was dry much of the time. During water years 1979-86, mean annual release increased to about 220,000 acre-ft, and in water year 1987 , the largest historical annual release $(539,300$ acre-ft) occurred. In water year 1988, the release volume decreased, but still remained large $(294,900$ acre-ft):

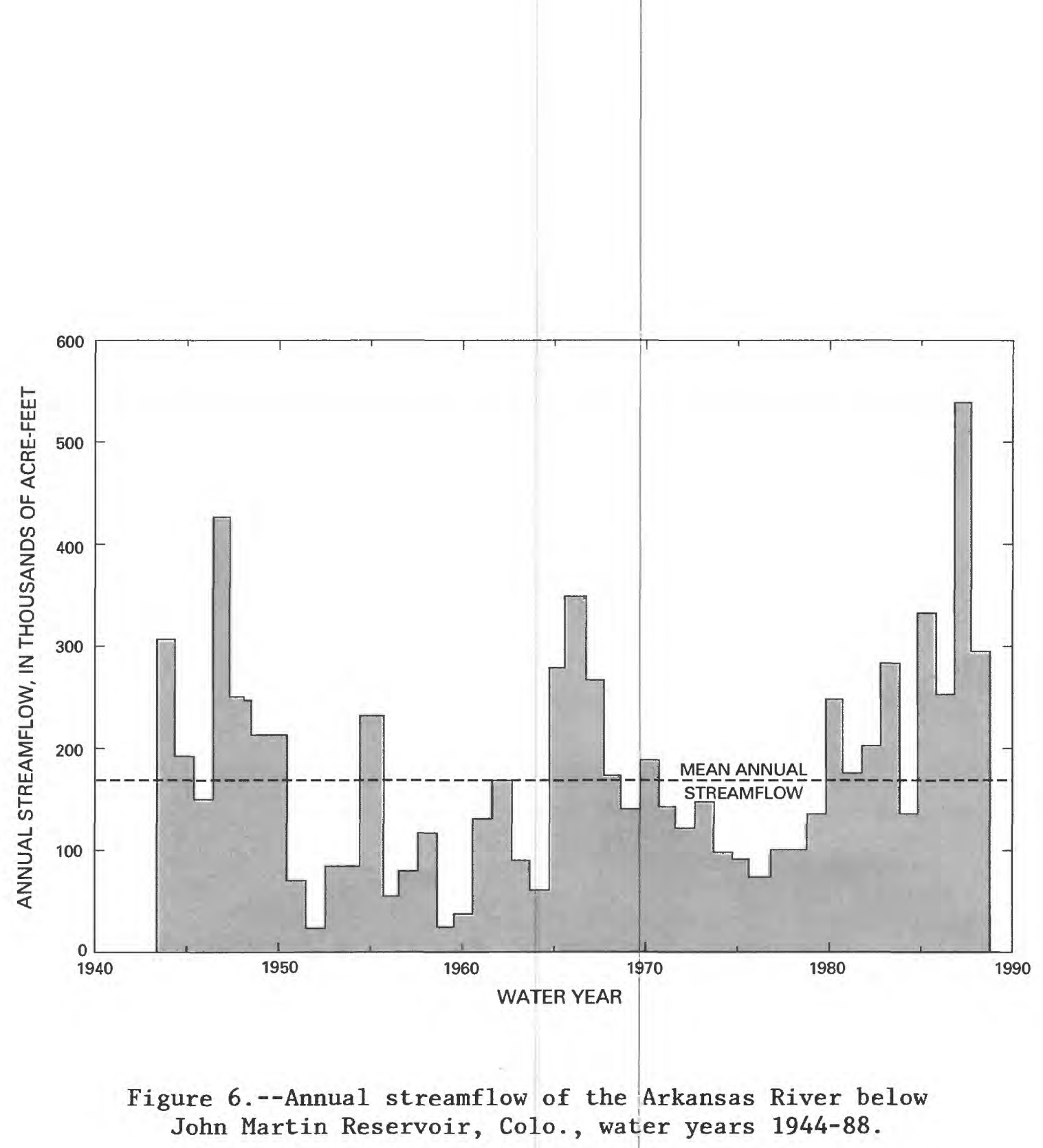




\section{$\underline{\text { Return Flows }}$}

Irrigation-drain water flows to the Arkansas River in tributary streams, in drainage ditches, and through the alluvial aquifer. The locations of numerous irrigation drains in the study area in Colorado were documented by Cain (1985). Some of these drains are extensive, well-maintained systems, whereas others are simply small, unmaintained ditches or channels. Minimal documentation exists concerning irrigation return flows to the Arkansas River in Kansas, but types of irrigation drainage similar to those in Colorado may be present. Minimal information is available to quantify the volume of return flow in either State.

Much of the streamflow in the Arkansas River downstream from La Junta may be irrigation return flow during parts of most years; therefore, any water that is diverted from this reach of the river may be affected by irrigation drainage (Cain, 1985). Also, the entire alluvial aquifer may be affected by irrigation drainage, either through recharge from the river or by direct percolation of irrigation water through soils.

\section{Ground Water}

The principal source of ground water in the Arkansas River basin in Colorado is the alluvial aquifer. This aquifer ranges from almost 0 to about $300 \mathrm{ft}$ in thickness and from 3 to $6 \mathrm{mi}$ in width (Taylor and Luckey, 1974). Saturated thickness in the alluvial deposits ranges from almost 0 to $100 \mathrm{ft}$, and depth to water ranges from almost 0 to $75 \mathrm{ft}$ below land surface.

West of the Bear Creek fault (fig. 3), the alluvium fills a trough that is eroded into shale, limestone, and sandstone bedrock. The bedrock is relatively impermeable and is a barrier to downward water movement. The alluvial aquifer in this area is recharged primarily by irrigation drainage, seepage from the river, and regional ground-water inflow in the area of Coolidge (Luckey, 1975; Barker and others, 1983). Within the alluvial aquifer, water flows to the southeast under a hydraulic gradient of about $8 \mathrm{ft} / \mathrm{mi}$. Water is discharged from the aquifer by well pumpage, seepage to the river, evapotranspiration from shallow water-table areas, and outflow to the Bear Creek fault zone.

East of the Bear Creek fault, the alluvial aquifer overlies unconsolidated material of the Ogallala Formation to which it is hydraulically connected (Dunlap and others, 1985). This aquifer system is recharged by inflow from the part of the alluvial aquifer west of the fault, by ground-water inflow from deposits of Pleistocene age north of the Arkansas River valley, by infiltration of precipitation and irrigation water, and by seepage from the Arkansas River and irrigation canals. Saturated thickness is about $50 \mathrm{ft}$ near the fault zone but decreases to almost zero between Lakin and Garden City. This decrease is due to leakage from the alluvial aquifer to the underlying Ogallala Formation, which has been pumped for irrigation for many years (Dunlap and others, 1985). 


\section{PREVIOUS STUDIES}

Miles (1977) published the first report relating irrigation and waterquality in the study area. Based on data collected by the U.S. Bureau of Reclamation and the U.S. Geological Survey, he concluded that irrigation return flows accounted for 14 percent of the salinity (dissolved-solids) loading to the Arkansas River in Colorado. He attributed most of this loading to dissolution of gypsum (calcium sulfate) from irrigated soils. Gypsum is a common mineral in soils that are derived from marine shales. Cain (1985) investigated irrigation return flows between Pueblo and the Colorado-Kansas State line during the 1976 and 1977 irrigation seasons. He reported that return flows may comprise much of the Arkansas River flow downstream from La Junta during the early and late parts of the irrigation season. Neither of these reports included information about selenium or other trace constituents; however, dissolved-selenium concentrations have been analyzed in water samples from the Arkansas River near Coolidge since 1975. The median concentration of 51 samples collected through water year 1987 was $19 \mu \mathrm{g} / \mathrm{L}$. Historical totalselenium concentrations at other locations in the study area are listed in table 1 .

Table 1.--Median concentrations of total selenium from historical data collected at water-quality monitoring sites in the study area ${ }^{1}$

$[\mu \mathrm{g} / \mathrm{L}$, micrograms per liter]

\begin{tabular}{|c|c|c|c|c|}
\hline $\begin{array}{l}\text { U.S. Geological } \\
\text { Survey station } \\
\text { number }\end{array}$ & $\begin{array}{l}\text { U.S. Geological } \\
\text { Survey station } \\
\text { name }\end{array}$ & $\begin{array}{l}\text { Number } \\
\text { of } \\
\text { samples }\end{array}$ & $\begin{array}{l}\text { Median } \\
\text { concen- } \\
\text { tration } \\
(\mu g / L)\end{array}$ & $\begin{array}{l}\text { Period } \\
\text { of } \\
\text { record }\end{array}$ \\
\hline 07099200 & $\begin{array}{l}\text { Arkansas River near } \\
\text { Pueblo, Colo. }\end{array}$ & 4 & 4.0 & $1976-79$ \\
\hline 07106300 & $\begin{array}{l}\text { Fountain Creek near } \\
\text { Pinon, Colo. }\end{array}$ & 44 & 4.0 & $1976-83$ \\
\hline 07106500 & Fountain Creek at Pueblo, & Colo. & 18 & $1976-83$ \\
\hline $\begin{array}{l}381130104341600 \\
381202104324700\end{array}$ & $\begin{array}{l}\text { St. Charles River near } \\
\text { Pueblo, Colo. (two sites }\end{array}$ & 8 & 30 & $1979-80$ \\
\hline 381556104273300 & $\begin{array}{l}\text { St. Charles River at mouth } \\
\text { near Vineland, Colo. }\end{array}$ & 4 & 23.5 & $1976-79$ \\
\hline 07109500 & $\begin{array}{c}\text { Arkansas River near } \\
\text { Avondale, Colo. }\end{array}$ & 4 & 8.5 & $1976-79$ \\
\hline 07117000 & $\begin{array}{c}\text { Arkansas River near } \\
\text { Nepesta, Colo. }\end{array}$ & 4 & 11.5 & $1976-79$ \\
\hline 07130500 & $\begin{array}{l}\text { Arkansas River below John } \\
\text { Martin Reservoir, Colo. }\end{array}$ & 8 & 6 & $1980-81$ \\
\hline
\end{tabular}

${ }^{1}$ Data from Cain and Edelmann (1980) and U.S. Geological Survey (1982-84). 
Selenium concentrations in ground water produced from terrace deposits and from shallow alluvial aquifers north of the Arkansas River alluvium in Crowley and Kiowa Counties, Colo., frequently exceed $10 \mu \mathrm{g} / \mathrm{L}$ and can be greater than $100 \mu \mathrm{g} / \mathrm{L}$ (Cain and others, 1980; Mustard and Cain, 1981) even though these areas receive little or no irrigation drainage. Ground-water data from Kansas during 1976-81 are summarized by Spruil1 (1983). Selenium concentrations in 52 percent of the wells that were sampled in the alluvial aquifer along the Arkansas River exceeded the Kansas drinking-water standard $(10 \mu \mathrm{g} / \mathrm{L})$. In addition, data from wells in the Ogallala aquifer indicate elevated concentrations of selenium may be present in areas receiving seepage from the Arkansas River.

Sulfate concentrations in four shallow wells (less than $100 \mathrm{ft}$ deep) near Syracuse, Kans., which were sampled during 1897 through 1907, ranged from $291 \mathrm{mg} / \mathrm{L}$ to $962 \mathrm{mg} / \mathrm{L}$ (Parker, 1911). The maximum dissolved-solids concentration was $1,800 \mathrm{mg} / \mathrm{L}$. In 1940 , the sulfate concentration in water from a shallow well located in this same area was $2,800 \mathrm{mg} / \mathrm{L}$, and the dissolved solids concentration was $4,600 \mathrm{mg} / \mathrm{L}$ (Latta, 1944). Sulfate concentrations in three wells sampled in the same area during 1977-88 were between 1,400 and $3,000 \mathrm{mg} / \mathrm{L}$, and dissolved-solids concentrations ranged from $2,250 \mathrm{mg} / \mathrm{L}$ to more than 5,000 mg/L (U.S. Geological Survey, 1978-89). Based on these data, concentrations of sulfate and dissolved, solids in the alluvial ground water seem to have increased substantially between 1907 and 1940 and then stabilized. The primary development of irrigated agriculture in the study area also occurred during 1907-40.

Seepage from the alluvial aquifer to the deeper Ogallala aquifer is indicated by lateral and vertical trends in sulfate and dissolved-solids concentrations (Latta, 1944). Higher sulfate and dissolved-solids concentrations were detected in deep wells in the Ogallala aquifer near the Arkansas River valley than in wells located north and south of the valley. Within the Arkansas River valley, near Garden City, sulfate and dissolvedsolids concentrations in the Ogallala aquifer decreased with depth.

Little previous data have been collected on aquatic biota in the study area. Samples of four fish species collected from Pueblo Reservoir in 1985 were analyzed for mercury by the Colorado Division of Wildlife (Rosenlund, 1986). Fillet samples contained less than about $0.25 \mu \mathrm{g} / \mathrm{g}$ of mercury (weight basis not reported). The Kansas Department of Health and Environment, in cooperation with the U.S. Environmental Protection Agency, has monitored as many as 43 selected priority pollutants in common carp (or alternate species) collected at 20 Kansas stations since 1980 (Cringan, 1989). A11 of the sampling stations, including those on the Arkansas River, are more than $100 \mathrm{mi}$ east of Deerfield, Kans. (fig. 2). Chlordane was the contaminant of greatest environmental and human-health concern. Selenium was not included in the program. 


\section{SAMPLE COLLECTION AND ANALYSIS}

\section{Objectives}

For this reconnaissance investigation, sample collection was designed to evaluate the chemical quality of water, bottom sediment, and biota in the Arkansas River, selected tributaries, and the alluvial aquifer during peak irrigation return flow, and in selected on- and off-channel reservoirs during and after the irrigation season. Stream sampling sites were limited to existing streamflow-measurement and water-quality monitoring stations. Because the study area was large, sampling of individual irrigation drains was not included.

Samples of water, bottom sediment, and biota were collected at all surface-water sites. Stream and ground-water sites were sampled in August, when natural streamflow was expected to be low and irrigation return flows were expected to be substantial. Reservoir sites were sampled in June and October to include the waterfowl nesting season and fall migration. Bottomsediment samples from reservoir sites were collected only in October. Biota samples collected from reservoir sites in June and October included birds, fish, invertebrates, and aquatic plants. Only fish and invertebrates were collected at stream sites in August. The number of samples collected at stream, reservoir, and ground-water sites is listed in table 2 .

Samples were analyzed for the constituents listed in table 3 . All samples were analyzed for inorganic constituents, primarily trace elements, associated with known irrigation-drainage problems. Reservoir water samples collected in October were analyzed for selected soluble herbicides that may have been applied in the study area. Bottom-sediment and selected biota samples from reservoir sites and fish samples from stream sites were analyzed for selected organochlorine pesticides. Although these pesticides were not being used on agricultural lands in the study area during the study period, they may have been used in the past. Because they are persistent, bioaccumulate in plant and animal tissue, and have harmful effects on animal populations, analyses of selected samples were necessary to test for the existence of a current (1988) problem resulting from past pesticide usage.

Table 2.--Number of samples collected during the study

\begin{tabular}{|c|c|c|c|c|}
\hline \multirow{2}{*}{$\begin{array}{l}\text { Sampling } \\
\text { matrix }\end{array}$} & \multirow{2}{*}{$\begin{array}{l}\text { Stream } \\
\text { sites }\end{array}$} & \multicolumn{2}{|c|}{ Reservoir sites } & \multirow{2}{*}{$\begin{array}{c}\text { Ground-water } \\
\text { sites }\end{array}$} \\
\hline & & June & October & \\
\hline Water & 9 & 5 & 7 & 5 \\
\hline Bottom sediment & 8 & 0 & 5 & 0 \\
\hline Birds ${ }^{1}$ & 0 & 67 & 52 & 0 \\
\hline Fish ${ }^{2}$ & 17 & 20 & 22 & 0 \\
\hline Invertebrates & 5 & 2 & 0 & 0 \\
\hline Aquatic plants & 0 & 8 & 0 & 0 \\
\hline
\end{tabular}

${ }^{1}$ Most samples are of individuals.

${ }^{2}$ Most samples are composites. 
Table 3.--Constituents analyzed in water, bottom-sediment, and biota samples collected during the study

$[--$, not analyzed $]$

\begin{tabular}{|c|c|c|c|}
\hline $\begin{array}{l}\text { Chemical group } \\
\text { and constituent }\end{array}$ & Water & $\begin{array}{l}\text { Bottom } \\
\text { sediment }\end{array}$ & Biota \\
\hline \multicolumn{4}{|l|}{ INORGANIC } \\
\hline Alkalinity & $\mathrm{x}$ & -- & -- \\
\hline Aluminum & -- & -- & $\mathrm{x}$ \\
\hline Arsenic & $\mathrm{x}$ & $\mathrm{x}$ & $\mathrm{x}$ \\
\hline Barium & -- & -- & $\mathrm{x}$ \\
\hline Beryllium & -- & -- & $\mathrm{x}$ \\
\hline Boron & $\mathrm{x}$ & $\mathrm{x}$ & $\mathrm{x}$ \\
\hline Calcium & $\mathrm{x}$ & -- & -- \\
\hline Cadmium & $\mathrm{x}$ & $\mathrm{x}$ & $\mathrm{x}$ \\
\hline Chloride & $\mathrm{x}$ & -- & -- \\
\hline Chromium & $\mathrm{x}$ & $\mathrm{x}$ & $\mathrm{x}$ \\
\hline Copper & $\mathrm{x}$ & $\mathrm{x}$ & $\mathrm{x}$ \\
\hline Iron & -- & -- & $\mathrm{x}$ \\
\hline Lead & $\mathrm{x}$ & $\mathrm{x}$ & $\mathrm{x}$ \\
\hline Magnesium & $\mathrm{x}$ & -- & $\mathrm{x}$ \\
\hline Manganese & -- & -- & $\mathrm{x}$ \\
\hline Mercury & $\mathrm{x}$ & $\mathrm{x}$ & $\mathrm{x}$ \\
\hline Molybdenum & $\mathrm{x}$ & $\mathrm{x}$ & $\mathrm{x}$ \\
\hline Nickel & -- & $\mathrm{x}$ & $\mathrm{x}$ \\
\hline Nitrite plus nitrate as nitrogen & $\mathrm{X}$ & -- & -- \\
\hline Potassium & $\mathrm{x}$ & -- & -- \\
\hline Selenium & $\mathrm{x}$ & $\mathrm{x}$ & $\mathrm{x}$ \\
\hline Silver & -- & -- & $\mathrm{x}$ \\
\hline Sodium & $\mathrm{X}$ & -- & -- \\
\hline $\begin{array}{l}\text { Solids, residue on evaporation } \\
\text { at } 180 \text { degrees Celsius }\end{array}$ & $\mathrm{x}$ & -- & -- \\
\hline Strontium & -- & -- & $\mathrm{x}$ \\
\hline Sulfate & $\mathrm{x}$ & -- & -- \\
\hline Thallium & -- & -- & $\mathrm{x}$ \\
\hline Uranium & $\mathrm{x}$ & $\mathrm{x}$ & -- \\
\hline Vanadium & $\mathrm{x}$ & $\mathrm{x}$ & $\mathrm{x}$ \\
\hline Zinc & $\mathrm{x}$ & $\mathrm{x}$ & $\mathrm{x}$ \\
\hline \multicolumn{4}{|l|}{ ORGANIC } \\
\hline $2,4-D$ & $\mathrm{x}$ & -- & -- \\
\hline $2,4,5-\mathrm{T}$ & $\mathrm{x}$ & -- & -- \\
\hline $2,4,5-\mathrm{DP}$ & $\mathrm{x}$ & -- & -- \\
\hline Aldrin & -- & -- & $\mathrm{x}$ \\
\hline$\alpha$-Benzenehexachloride & -- & -- & $\mathrm{x}$ \\
\hline$\beta$-Benzenehexachloride & -- & -- & $\mathrm{x}$ \\
\hline Benzenehexachloride & -- & -- & $\mathrm{x}$ \\
\hline
\end{tabular}


Table 3.--Constituents analyzed in water, bottom-sediment, and biota samples collected during the study--Continued

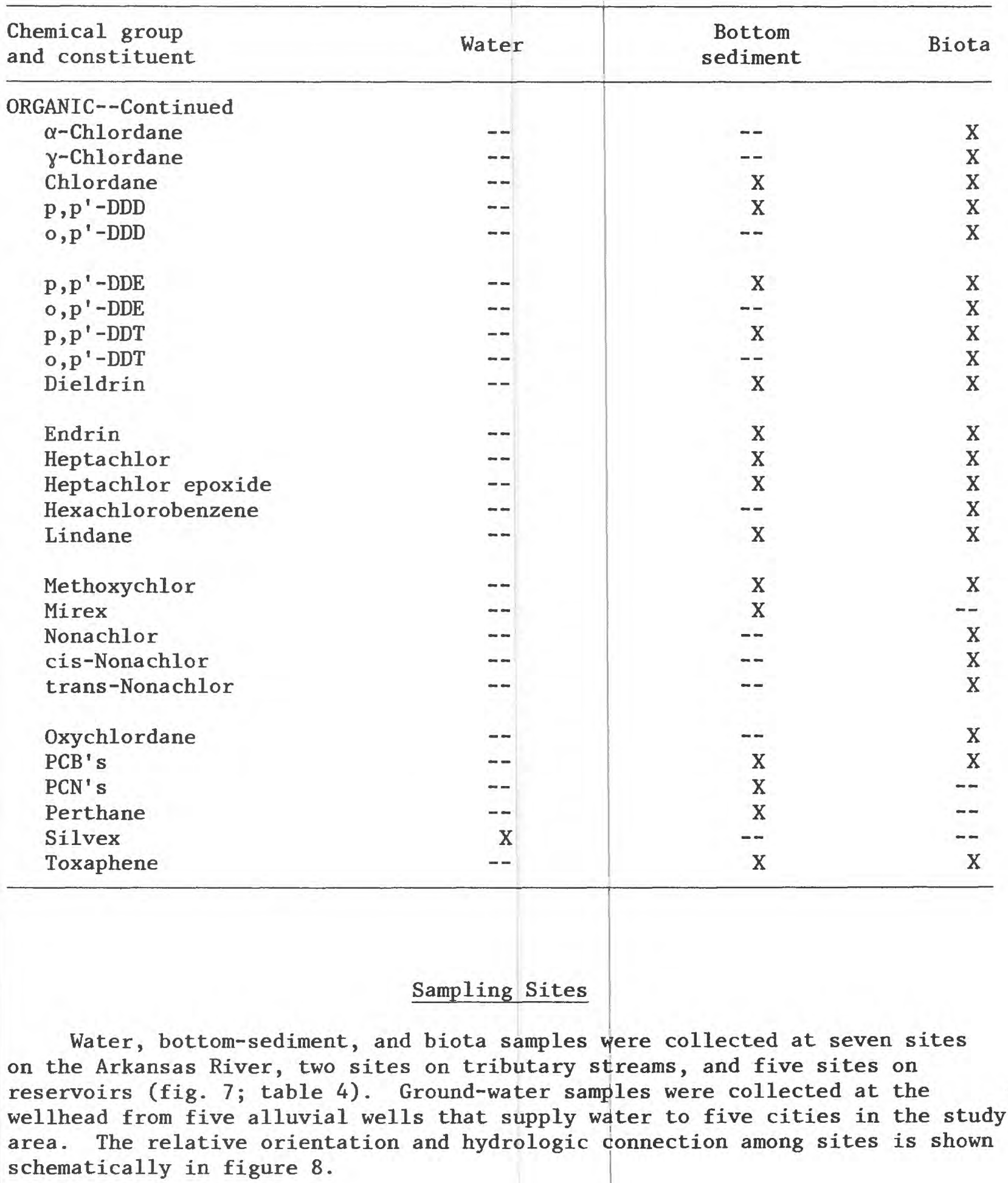



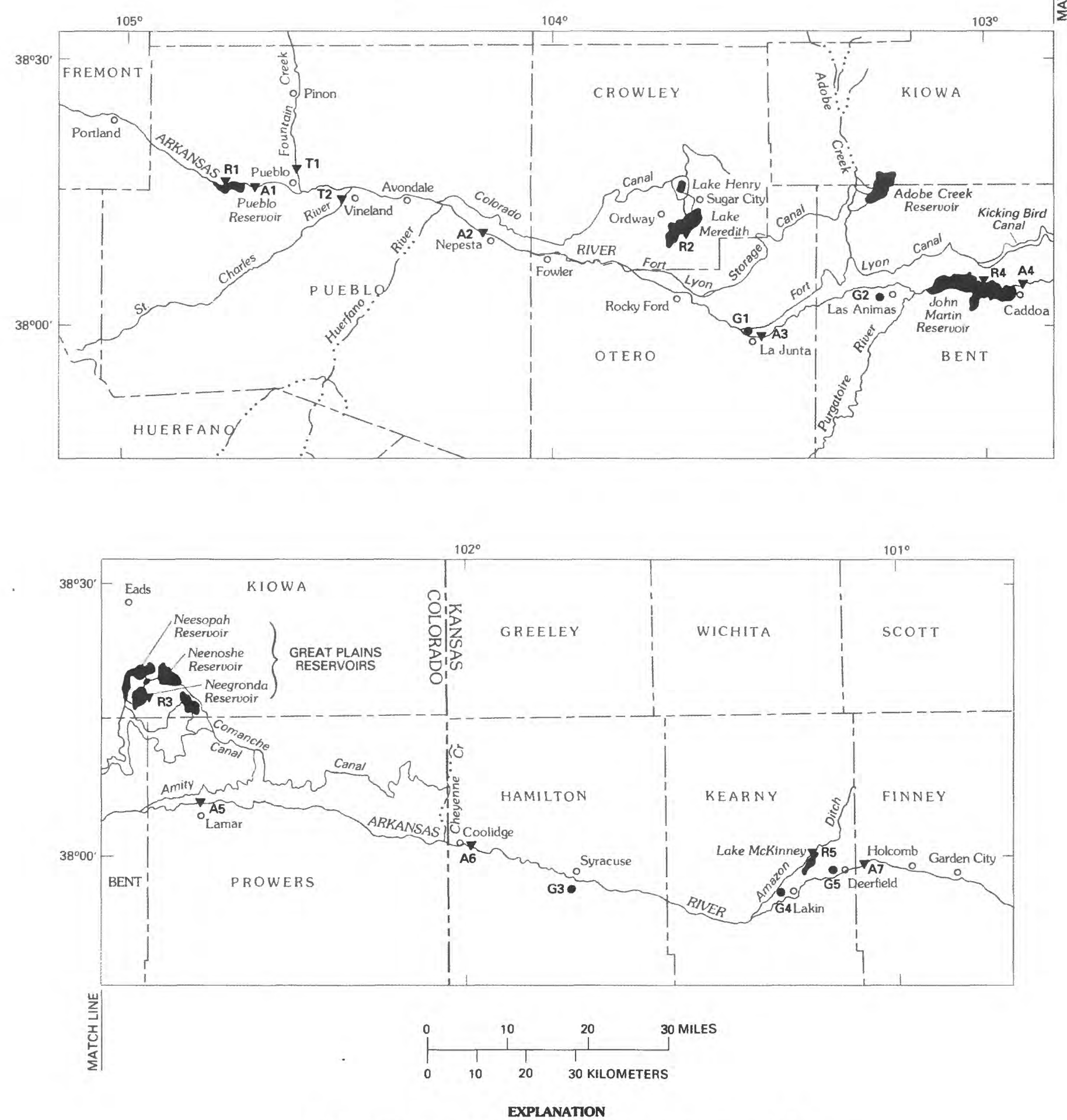

R1 $\nabla$ SURFACE-WATER SAMPUNG SITE-Number refers to site number in table 4

G1 GROUND-WATER SAMPUING SITE-Number refers to site number in table 4

Figure 7.--Location of sampling sites in the study area. 
Table 4.--Identification of stream, reservoir, and ground-water sites sampled in the study area

[--, no station number]

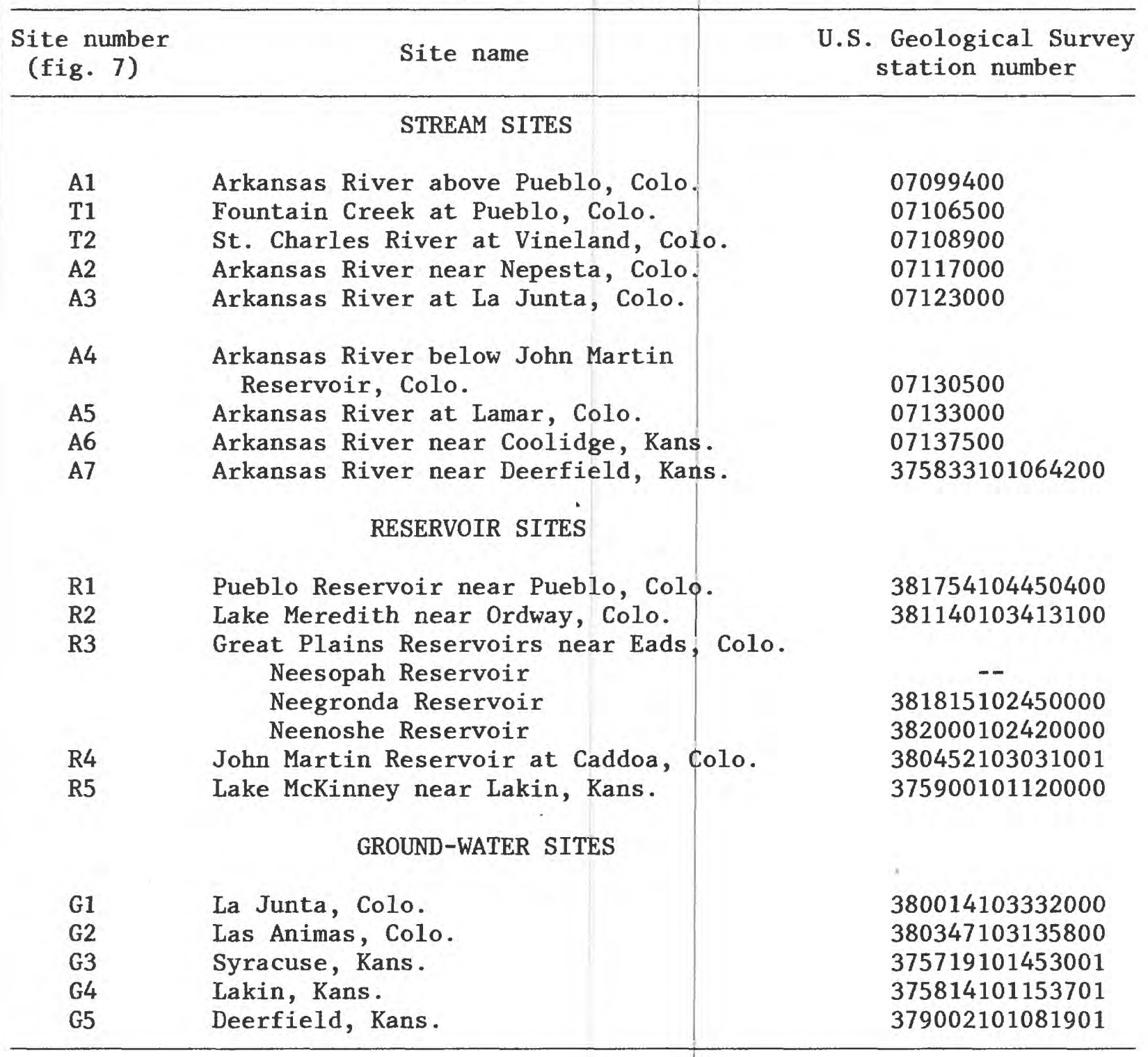

The stream sampling site upstream from Pueblo (site A1) and the site near Deerfield (site A7) were selected to represent inflow and outflow from the study area. The site near Coolidge (site A6) is the NASQAN station for which high concentrations of selenium have been reported in the past (1975-87). The site downstream from John Martin Reservoir was selected because the reservoir completely regulates streamflow in the Arkansas River. The remaining Arkansas River sites (sites A2, A3, and A5) are at existing streamflow-gaging stations and were selected to provide adequate representation of the river. The two tributary sites (sites $\mathrm{T} 1$ and $\mathrm{T} 2$ ) represent inflow from areas of known selenium loading. 


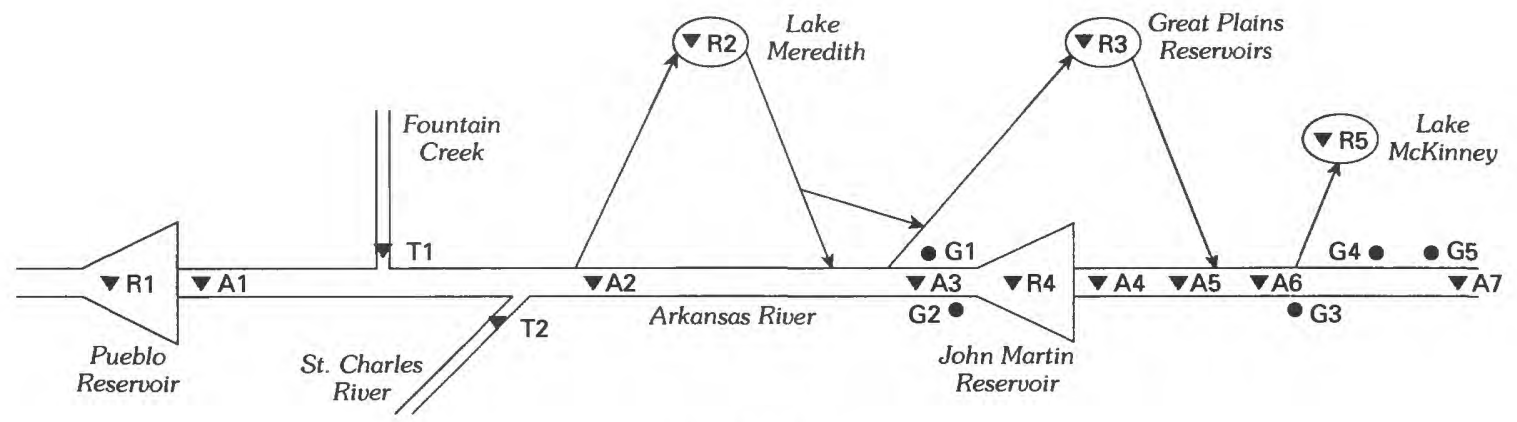

EXPLANATION

- R1 SURFACE-WATER SAMPLING ȘITE--Number refers to site number in table 4

- G1 GROUND-WATER SAMPLING SITE--Number refers to site number in table 4

Figure 8.--Relative orientation of sampling sites and major streams, reservoirs, and canals in the study area.

Water samples from Pueblo and John Martin Reservoirs (sites R1 and R4) and from Lake Meredith (site R2) were collected at locations established for previous monitoring projects. An inflow location was selected at Pueblo Reservoir to represent conditions near the upstream end of the study area. All other reservoirs were sampled at a central location. Bottom-sediment samples were collected from shallow areas near inflow locations. Biota samples were collected at various locations in and around the reservoirs, depending on habitat distribution and species availability. Samples were collected from three reservoirs in the Great Plains Reservoirs, which were assumed representative of a single site (site R3). This site is located east of John Martin Reservoir (site R4) but receives water diverted from the Arkansas River upstream from site R4.

The sampled wells were completed in shallow alluvium that is hydraulically connected to the Arkansas River. The sites in Colorado were selected because the wells supply water to large populations. The Kansas sites were selected because the wells had the highest concentrations of selenium detected during previous surveys. Several municipal wells were available for sampling at each site; therefore, specific conductance was measured in water pumped from each well at the site, and the well that had the largest specificconductance value was selected for sampling. 


\section{Sampling Methods}

All samples were collected using standard/techniques (U.S. Geological Survey, 1977). Stream-water samples were obtained using an epoxy-coated US DH-48 or US D-49 sampler and depth-integrating procedures (Guy and Norman, 1970; Edwards and Glysson, 1988). Water samples from reservoirs were collected using a polyvinylchloride Van Dorn sampler. Depth profiles of specific conductance, $\mathrm{pH}$, temperature, and dissolved oxygen were measured at the time of sampling. All water samples were passed through a $0.45-\mu \mathrm{m}$ filter and preserved at the sampling site.

Bottom-sediment samples from stream and reservoir sites were collected using a US BMH-60 sampler that had a stainless steel scoop. Samples from several locations at each site were composited in a stainless steel bucket, and a subsample was removed using a wooden spopn. At some shallow stream sites, bottom sediment was scooped directly info the bucket using a wooden spoon. Bottom sediment was not sampled at the Arkansas River above Pueblo (site A1) because the streambed was completely armored with coarse cobbles.

Variable numbers of adult and prefledged mallards, American coots, and other bird species were collected by taking birds from nests or by shooting them with steel shot. Livers of individual birds, or composites of three livers from killdeer, were analyzed for inorganic constituents. Two liver samples each of mallards and killdeer from all reservoir sites, except the Great Plains Reservoirs, were analyzed for organochlorine pesticides and PCB's. Two liver samples of double-crested cormorants from John Martin Reservoir also were analyzed for organic constituents. Samples of breast muscle and livers from the same individual birds were analyzed for inorganic constituents to assess the use of livers to predict concentrations in breast muscle. Breast-muscle concentrations may be of interest to human health authorities. In addition, whole or partial clutches of eggs of several bird species were collected during the nesting season at each reservoir site and analyzed for inorganic constituents.

One or more fish species were collected by using gill nets at reservoir sites and electroshocking equipment at stream sites in accordance with standard procedures (U.S. Fish and Wildlife Service, 1985). Species collected at stream sites were mostly bottom-feeding omnivores, including carp and suckers. Species collected from the reservoirs included bottom-feeding omnivores (typically carp), carnivores (typically bullhead catfish, bass, or walleye), and filter feeders (typically gizzard shad). For each species, three individual fish of similar length were composited, producing one sample of a species per site per sampling period. Each sample was analyzed for inorganic constituents. Samples of two species each from Pueblo Reservoir and Lake McKinney were analyzed for organochlorine pesticides and PCB's. Samples of common carp from stream sites $\mathrm{A} 2, \mathrm{~A} 3, \mathrm{~A} 5$, and $\mathrm{A} 7$ also were analyzed for organochlorine pesticides and $P C B$ 's.

Composite samples of an abundant invertebrate species (typically crayfish) and an abundant species of submerged aquatic vegetation (typically algae and pond weed) were collected, where available, at reservoir sites during the June sampling period. The species varied among the sites. Whole crayfish were obtained with electroshocking equipment, and several individuals 
were composited into each sample. Aquatic plants, exclusive of roots, were collected by hand and were rinsed free of inorganic debris with site water before placing in a sample container. All inorganic samples were placed in either chemically-clean glass jars (bird livers and eggs) or plastic bags (whole birds, fish, and crayfish). Samples for organic-compound analysis were placed in chemically-clean glass jars (livers) or wrapped in aluminum foil (whole fish). Samples were frozen onsite in dry ice, except for avian livers, which were removed by dissection and frozen late in the day of collection. Eggs were not frozen onsite but were refrigerated until the contents were removed and frozen within a few days of collection.

\section{Analytical Support}

Water samples were analyzed at the U.S. Geological Survey National Water Quality Laboratory in Arvada, Colo. Analyses were performed using analytical procedures described by Fishman and Friedman (1985) and quality-assurance practices described by Friedman and Erdman (1982). Bottom-sediment samples were analyzed for inorganic constituents at the U.S. Geological Survey Environmental Geochemistry Laboratory in Denver, Colo., using procedures described by Severson and others (1987). The sediment samples were air dried at the laboratory and passed through a 2-mm sieve. The samples then were split, and one split from each sample was passed through a $0.062-\mathrm{mm}$ sieve. Analyses were performed on both size fractions. Pesticide residues in bottom sediment were analyzed at the National Water Quality Laboratory using procedures described by Wershaw and others (1987). These samples were washed through a metal sieve at the sample site, and the less than 2-mm size fraction was analyzed.

All biological specimens were analyzed following procedures and quality assurance/quality control protocols prescribed by the U.S. Fish and Wildlife Service's Patuxent Analytical Control Facility in Laurel, Md. (U.S. Fish and Wildlife Service, 1985). Organic analyses of avian and fish samples from reservoirs were analyzed at Mississippi State Chemical Laboratory at Mississippi. State University. The minimum reporting limit was $0.01 \mu \mathrm{g} / \mathrm{g}$ wet weight. Organic analyses of fish samples from stream sites were performed at Texas A\&M Research Foundation in College Station, Texas. The minimum reporting limit was $0.05 \mu \mathrm{g} / \mathrm{g}$ wet weight. Concentrations of organic compounds were determined using organic solvent extraction followed by electron-capture gas chromatography. Inorganic analyses of all June samples from reservoirs were done at the Environmental Trace Substances Research Center in Columbia, Missouri, and the August and October samples were analyzed at Hazelton Laboratories America, Inc. in Madison, Wis. Reporting limits for elemental constituents varied with the element and method used. The methods used for inorganic analyses were: arsenic and selenium by hydride generation; mercury by cold vapor reduction; and the remaining elements by inductively coupled plasma emission spectroscopy (ICP). 


\section{DISCUSSION OF RESULTS}

Analyses of all samples collected during this reconnaissance investigation are reported in tables 8-20 in the "Supplemental Data" section at the back of this report. Separate tables are included for water quality in streams, reservoirs, and ground water; for chemical analyses of bottom sediment in streams and reservoirs; and for biota in streams and reservoirs. Tables of data from reservoir sites also are separated by sampling period (June or October).

\section{Determination of Elevated Concentrations}

Data collected during the reconnaissance investigation were compared to a variety of standards, criteria, and baseline values to determine whether samples contained elevated concentrations of particular constituents. These standards, criteria, and baselines included:

1. Water-quality standards for the States of Colorado (Colorado Department of Health, 1987, 1988) and Kansas (Kansas Department of Health and Environment, written commun., 1987), and the U.S. Environmental Protection Agency (1986 and 1987).

2. Geochemical baselines for soils from the Western United States (R.C. Severson, U.S. Geological Survey, written commun., 1987, based on data in Shacklette and Boerngen, 1984).

3. Concentrations of trace elements and organochlorine pesticides in fish and birds, based on national monitoring programs (Fleming and others, 1983; Lowe and others, 1985; Schmitt and others, 1985). (Baseline concentrations from Lowe and others (1985) were converted to dry weight using 71 percent moisture, as discussed by Lemly and Smith (1987).)

4. Concentrations of trace elements in $\mathrm{fish}$ associated with reproductive problems or decreased survival (Gillespie and Baumann, 1986).

5. Concentrations of trace elements in bird livers associated with reproductive problems or decreased survival (Beck, 1961; Finley and Stendell, 1978; Ohlendorf and others, 1978; White and Finley, 1978; Heinz and others, 1987; U.S. Fish and Wildlife Service, 1990).

6. Concentrations of trace elements in dietary material associated with reproductive problems or decreased survival of birds (Heinz, 1980; Eisler, 1987; Heinz and others, 1987; Camardese and others, 1990; Sparling, 1990; U.S. Fish and Wildlife Service, 1990).

The Colorado and Kansas water-quality standards and U.S. Environmental Protection Agency (EPA) criteria and maximum contaminent levels for properties and constituents analyzed in samples collected during the study are listed in tables 5 and 6 . Standards and criteria for protection of aquatic life are listed in table 5. Standards and criteria for chronic and acute exposure levels are presented. The aquatic-life standards for some trace elements are based on a relation between the element concentration and the hardness of the water. These standards are listed in table 5 as a range of concentrations for hardness values from 100 to $1,000 \mathrm{mg} / \mathrm{L}$, which were typical for water in the study area. Standards and maximum contaminant levels for domestic water and agricultural supplies are listed in table 6 . 
Table 5.--Colorado and Kansas water-quality standards and U.S. Environmental Protection Agency criteria for protection of aquatic life ${ }^{1}$

$[\mu \mathrm{g} / \mathrm{L}$, micrograms per liter; (EPA), U.S. Environmental Protection Agency criteria applied as State standard; --, no standard or criterion; $\hbar$, standard or criterion based on hardness (values are shown for a hardness range of $100-1,000 \mathrm{mg} / \mathrm{L}$ )]

\begin{tabular}{|c|c|c|c|c|c|c|}
\hline \multirow{2}{*}{$\begin{array}{l}\text { Property } \\
\text { or } \\
\text { constituent }\end{array}$} & \multirow[t]{2}{*}{ Units } & \multicolumn{2}{|c|}{ Colorado } & \multirow[t]{2}{*}{ Kansas } & \multicolumn{2}{|c|}{$\begin{array}{l}\text { U.S. Envi ronmental } \\
\text { Protection Agency }\end{array}$} \\
\hline & & Cnronic & Acuce & & Chronic & Acute \\
\hline $\mathrm{pH}$ & standard & $6.5-9.0$ & $6.5-9.0$ & $6.5-8.5$ & $6.5-9.0$ & $6.5-9.0$ \\
\hline Arsenic & $\mu_{g} / L$ & 150 & 360 & (EPA) & 190 & 360 \\
\hline Cadmium & $\mu_{g} / L$ & $1.1-6.9 x$ & $9.9-133^{*}$ & (EPA) & $1.1-6.9 *$ & $3.9-53^{*}$ \\
\hline Chromium (III) & $\mu \mathrm{g} / \mathrm{L}$ & $210-1,360$ & $1,740-11,450^{*}$ & (EPA) & $210-1,360 \div$ & $1,740-11,450 \div$ \\
\hline Chromium (VI) & $\mu_{g} / L$ & 11 & 16 & (EPA) & 11 & 16 \\
\hline Copper & $\mu_{g} / L$ & $12-85^{*}$ & $18-155^{*}$ & (EPA) & $12-85 *$ & $18-155^{x}$ \\
\hline Lead & $\mu_{g} / L$ & $3.9-102 \%$ & $96-3,950 *$ & (EPA) & $3.2-60=$ & $82-1,530 *$ \\
\hline Mercury & $\mu \mathrm{g} / \mathrm{L}$ & 0.1 & 2.4 & (EPA) & 0.012 & 2.4 \\
\hline Selenium & $\mu g / L$ & 17 & 135 & 35 & 5.0 & 20 \\
\hline Uranium & $\mu_{g} / L$ & $1,500-18,980^{*}$ & $2,400-30,400 \div$ & -- & - & -- \\
\hline Zinc & $\mu g / L$ & $45-990 *$ & $220-1,400$ & 47 & $110-746 *$ & $120-820 \%$ \\
\hline
\end{tabular}

${ }^{1}$ Sources: Colorado Department of Health, 1987 and 1988; Kansas Department of Health and Environment, written commun., 1987; U.S. Environmental Protection Agency, 1986 and 1987.

Table 6.--Colorado and Kansas water-quality standards and U.S. Environmental Protection Agency maximum contaminant levels for domestic water and agricultural supplies ${ }^{1}$

$[\mathrm{mg} / \mathrm{L}$, milligrams per liter; $\mu \mathrm{g} / \mathrm{L}$, micrograms per liter; --, no standard or maximum contaminant level; PMCL, proposed maximum contaminant level]

\begin{tabular}{|c|c|c|c|c|c|c|}
\hline \multirow{2}{*}{$\begin{array}{l}\text { Property } \\
\text { or } \\
\text { constituent }\end{array}$} & \multirow[b]{2}{*}{ Units } & \multicolumn{3}{|c|}{ Domestic water supply } & \multirow{2}{*}{$\frac{\text { Agricultural }}{\text { Colorado }}$} & \multirow{2}{*}{$\frac{\text { supply }}{\text { Kansas }}$} \\
\hline & & Colorado & Kansas & $\begin{array}{l}\text { U.S. Environmental } \\
\text { Protection Agency }\end{array}$ & & \\
\hline $\mathrm{pH}$ & standard & $5.0-9.0$ & $6.5-8.5$ & $5.0-9.0$ & -- & -- \\
\hline Dissolved solids & $\mathrm{mg} / \mathrm{L}$ & -- & 1,000 & - & -- & 2,500 \\
\hline Chloride & $\mathrm{mg} / \mathrm{L}$ & 250 & 250 & -- & -- & -- \\
\hline Sulfate & $\mathrm{mg} / \mathrm{L}$ & 250 & 250 & -- & -- & 1,000 \\
\hline Nitrate as nitrogen & $\mathrm{mg} / \mathrm{L}$ & 10 & 10 & 10 & -- & 100 \\
\hline Arsenic & $\mu g / L$ & 50 & 50 & 50 & 100 & 100 \\
\hline Boron & $\mu_{g} / L$ & -- & -- & -- & 750 & 750 \\
\hline Cadmium & $\mu_{g} / L$ & 10 & 10 & 10 & 10 & 10 \\
\hline Chromium & $\mu g / L$ & 50 & 50 & 50 & 100 & -- \\
\hline Copper & $\mu g / L$ & 1,000 & 1,000 & - & 200 & 200 \\
\hline Lead & $\mu_{g} / L$ & 50 & 50 & 50 & 100 & 100 \\
\hline Mercury & $\mu g / L$ & 2 & 2 & 2 & -- & - \\
\hline Selenium & $\mu g / L$ & 10 & 10 & 10 (PMCL 50) & 20 & 20 \\
\hline Zinc & $\mu_{g} / L$ & 5,000 & 5,000 & - & 2,000 & 2,000 \\
\hline $2,4-D$ & $\mu_{g} / L$ & 100 & 100 & -- & -- & -- \\
\hline $2,4,5-T$ & $\mu g / L$ & -- & 21 & -- & -- & -- \\
\hline Silvex & $\mu g / L$ & -- & 10 & -- & -- & - \\
\hline
\end{tabular}

${ }^{1}$ Sources: Colorado Department of Health, 1987 and 1988; Kansas Department of Health and Environment, written commun., 1987; U.S. Environmental Protection Agency, 1986 and 1987. 
Baseline values for selected elements in soils in the Western United States are listed in table 7. The upper limit of the expected 95-percent range was compared to measured values in bottom-sediment samples from the study area to identify elevated concentrations.

\section{Water Quality}

The concentrations of many constituents increased in a downstream direction at surface-water sampling sites in the study area. Concentrations of several constituents in samples from stream sites are plotted in figure 9. These constituents were selected because they are more concentrated in marine shales than in other rock formations that are exposed in the study area; therefore, high concentrations in surface water may indicate runoff from land underlain by marine shale or where marine shale is the parent material of the soil.

The patterns of concentrations for sulfate, boron, and uranium are similar. Concentrations were relatively low in the Arkansas River upstream from Pueblo (site A1) near the west end of the study area. Concentrations in the two tributaries were higher but were diluted by the larger volume of water in the Arkansas River, so concentrations increased only slightly in the Arkansas River near Nepesta, Colo. (site A2). Concentrations in the Arkansas River increased substantially at La Junta (site A3) and remained high at all sites downstream. Streamflow at site A3 in August was less than 10 percent of streamflow at site A2 (table 8). Most of the flow in the Arkansas River was diverted into irrigation and water-supply canals between these two sites. Water quality of the river downstream from these diversions seems to be affected by runoff from marine-shale areas. This effect is consistent with Cain's (1985) conclusion that much of the flow in the river downstream from La Junta is irrigation drainage during parts of most years.

Table 7.--Geochemical baselines for selected elements in soils in the Western United States (R.C. Severson, U.S. Geological Survey, written commun., 1987; based on data from Shacklette and Boerngen, 1984)

[Baseline is the upper limit of the expected 95-percent range; all values in micrograms per gram]

\begin{tabular}{lccc}
\hline Element & $\begin{array}{c}\text { Geometric } \\
\text { mean }\end{array}$ & $\begin{array}{c}\text { Geometric } \\
\text { deviation }\end{array}$ & $\begin{array}{c}\text { Expected } \\
\text { 95-percent range }\end{array}$ \\
\hline Arsenic & 5.5 & 1.98 & $1.2-22$ \\
Chromium & 41 & 2.19 & $8.5-200$ \\
Copper & 21 & 2.07 & $4.9-90$ \\
Lead & 17 & 1.80 & $5.2-55$ \\
Mercury & 0.046 & 2.33 & $0.0085-0.25$ \\
Molybdenum & 0.85 & 2.17 & $0.18-4.0$ \\
Nickel & 15 & 2.10 & $3.4-66$ \\
Selenium & 0.23 & 2.43 & $0.039-1.4$ \\
Uranium & 2.5 & 1.45 & $1.2-5.3$ \\
Vanadium & 70 & 1.95 & $18-270$ \\
Zinc & 55 & 1.79 & $17-180$
\end{tabular}



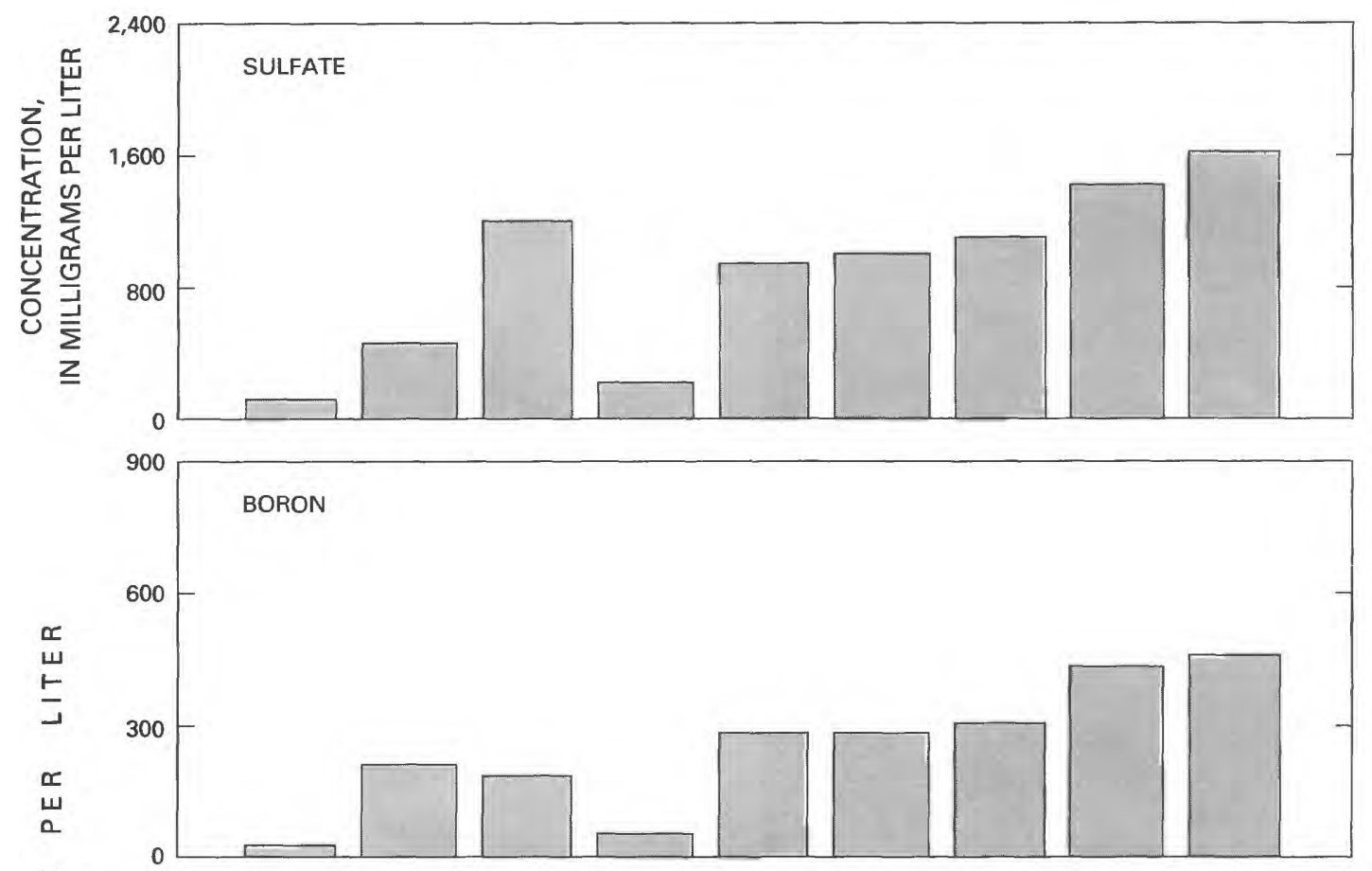

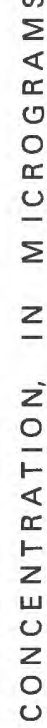
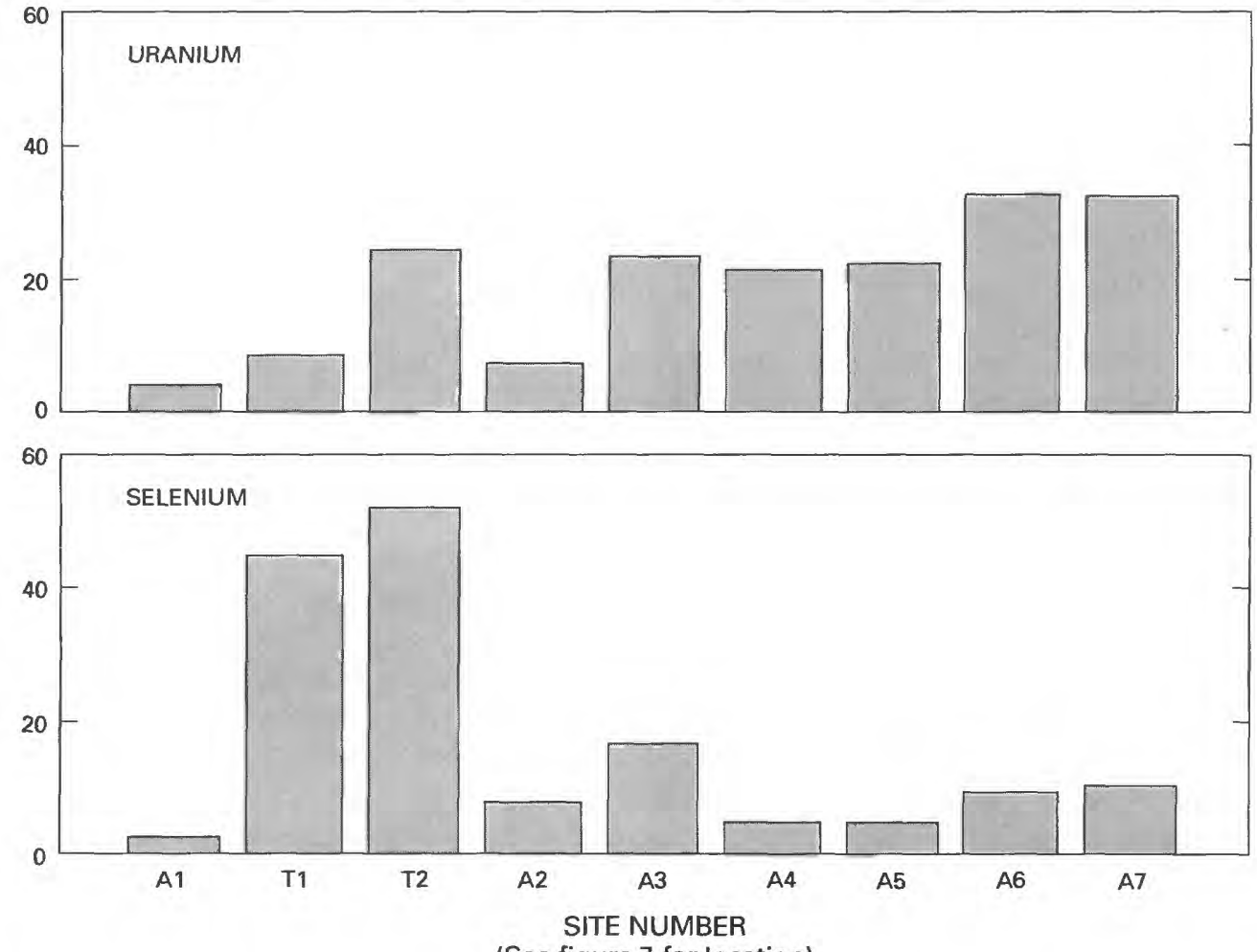

(See figure 7 for location)

Figure 9.--Concentrations of selected constituents in samples from stream sites, August 1988. 
The pattern of selenium concentrations shown in figure 9 is different from the other constituents. The selenium concentration was low at the upstream site and high in the tributaries, and the same dilution effect occurred at site A2. The concentration increased at site A3, although proportionally less than for the other constituents. The concentration then decreased downstream from John Martin Reservoif (site A4) and increased only slightly at the downstream sites. Selenium concentration may be affected by some process occurring in John Martin Reservoir. The geologic sources of selenium may not be as extensive downstream from the reservoir.

The patterns of sulfate, boron, and uranium concentrations also were similar at the reservoir sites (fig. 10). All|the reservoirs, except Pueblo Reservoir (site R1), near the upstream end of the study area, seem to be affected by runoff from marine-shale areas. Lake Meredith (site R2) and Lake McKinney (site R5) seem to be affected to the greatest extent. Concentrations in Lake Meredith were substantially higher than in the Arkansas River near Nepesta (site A2), which is near the point of diversion for inflow to the lake. Some other source, perhaps runoff from irrigated areas near the lake, may be contributing constituent loads to the lake. A similar situation occurs at Lake McKinney and may be contributing to concentrations that are somewhat larger than inflow values. Little direct irrigation runoff accumulates in the Great Plains Reservoirs (site R3) or John Martin Reservoir (site R4). Concentrations of sulfate, boron, and uranium at site $\mathrm{R} 4$ were similar to those at stream sites $\mathrm{A} 3$, upstream, and $\mathrm{A} 4$, downstream from the reservoir.

Selenium concentrations were low $(1-10 \mu \mathrm{g} / \mathrm{L})$ in all reservoir samples. As indicated by the data upstream and downstream from John Martin Reservoir, some processes may affect selenium concentration in reservoirs. If such a process is occurring, dissolved selenium may be removed from the water and possibly stored in the biota or bottom sediment. Oremland and others (1989) have demonstrated the possibility of such a process involving bacterial reduction of selenate under anoxic conditions.

The concentration patterns of all four constituents were similar to each other in samples from the ground-water sites (fig. 11). Unlike the surfacewater sites, the highest concentrations occurred at the more upstream groundwater sites. The sites that seem most affected by recharge from marine-shale areas are at La Junta (site G1) and at Las Animas (site G2). These sites are downstream from the Fort Lyon storage canal diversion and upstream from John Martin Reservoir, which is the area where the largest increases in concentration were detected in the Arkansas River. This area also is near extensive outcrops of the Carlile Shale and the Niobrara Formation, which contains seleniferous marine shale. Constituent concentrations at site G1 were similar to those in the Arkansas River at La Junta (site A3); but at site G2, concentrations were much larger than at site A3. Concentrations were low at Syracuse (site G3). This site is south of the Arkansas River in an area that may receive dilute recharge water from precipitation on sand dunes. At Lakin (site G4) and Deerfield (site G5), concentrations were slightly larger than at site G3 but, except for selenium, were less than those in the Arkansas River near Deerfield (site A7). Sites G4 and G5 also may be receiving recharge from a source more dilute than seepage from the river. 

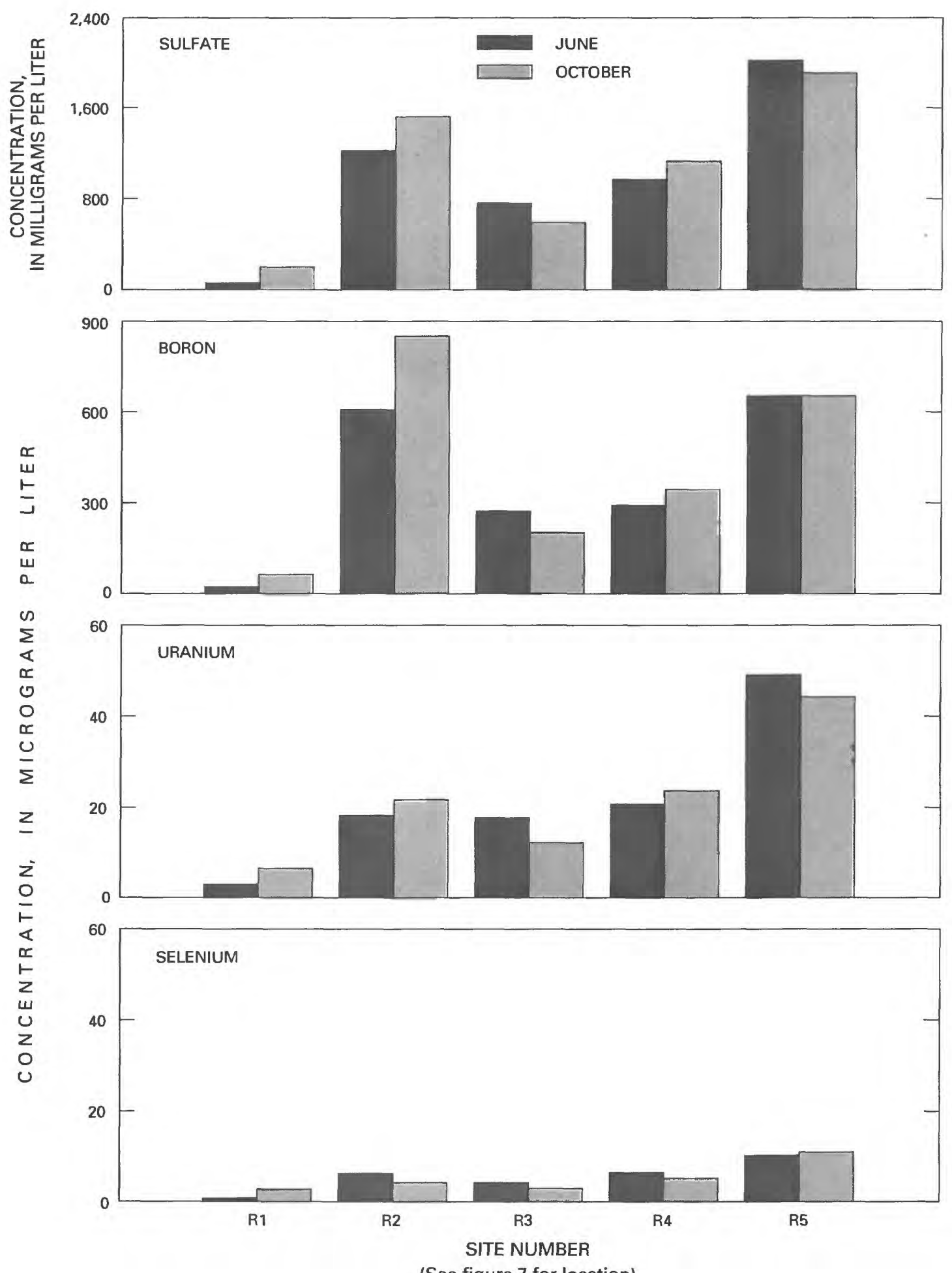

(See figure 7 for location)

Figure 10.--Concentrations of selected constituents in samples from reservoir sites, June and October 1988. 


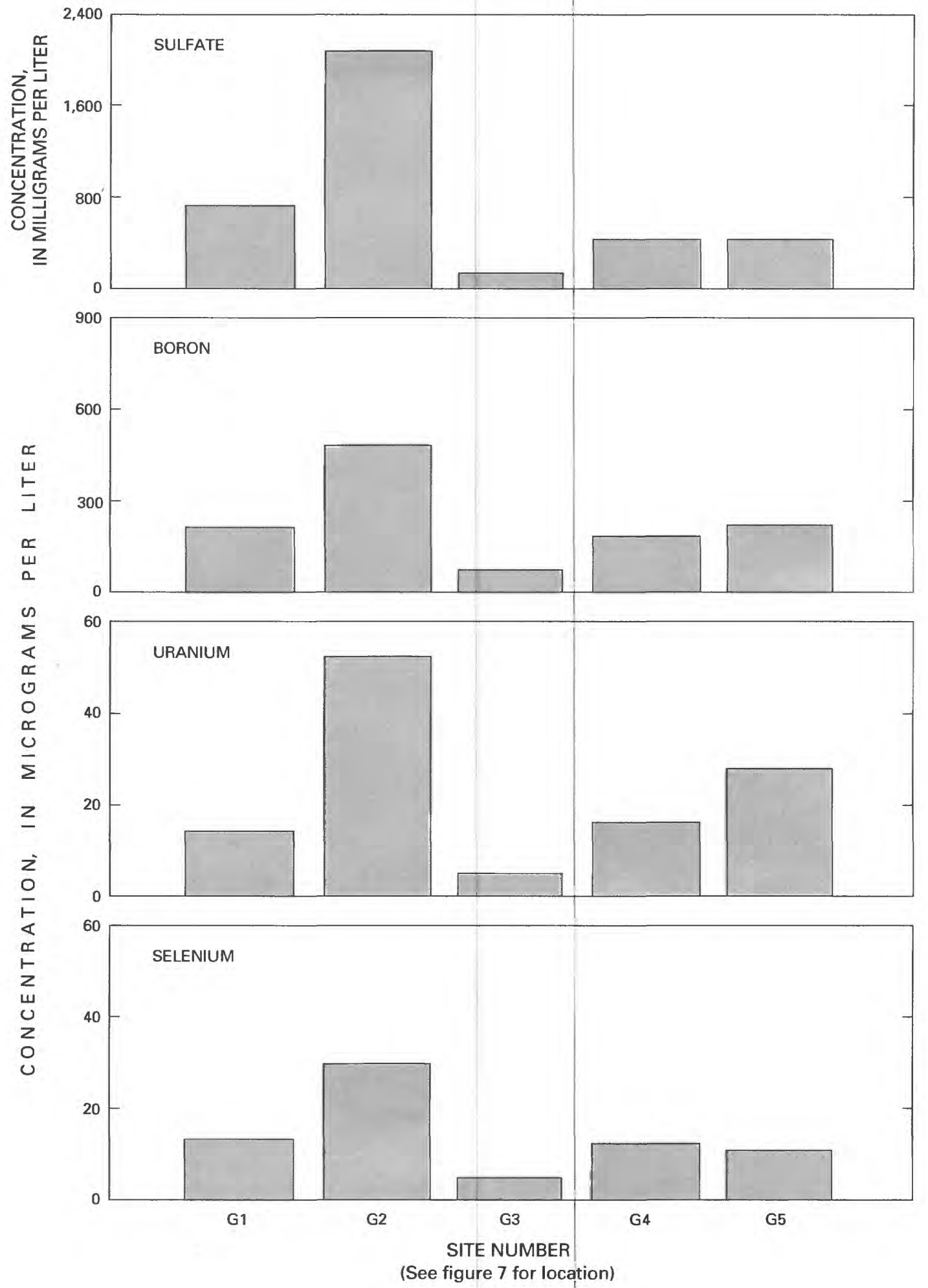

Figure 11.--Concentrations of selected constituents in samples from ground-water sites, August 1988. 
A total of 21 water samples from surface-water (stream and reservoir) sites and 5 samples from ground-water sites were collected during the study. The State domestic-water-supply standard of $250 \mathrm{mg} / \mathrm{L}$ for sulfate (table 6) was exceeded in 17 of the surface-water samples (tables 8-10) and in 4 of the ground-water samples (table 11). The only sites where this standard was not exceeded were near the upstream end of the study area (sites A1, A3, and R1) and the ground-water site at Syracuse (site G3), which may be recharged from the sand-dune area. The State standard and U.S. EPA maximum contaminant level of $10 \mu \mathrm{g} / \mathrm{L}$ for selenium in domestic-water supply (table 6) was exceeded at three surface-water sites (T1, T2, and $\mathrm{A} 3$ ) and in three ground-water sites (G1, G2, and G4). Two of these surface-water sites (T1 and T2) are tributaries that contributed little streamflow to the Arkansas River at the time of sampling. Sites A3, G1, and G2 are located in the area between La Junta and John Martin Reservoir, where runoff from marine-shale areas seems to have its most significant effect in the study area. The selenium concentration in surface water from the La Junta area (site A3) was $17 \mu \mathrm{g} / \mathrm{L}$ (table 8). The concentration in ground water was $12 \mu \mathrm{g} / \mathrm{L}$ at La Junta (site G1) and $29 \mu \mathrm{g} / \mathrm{L}$ at Las Animas (site G2), which is about $17 \mathrm{mi}$ downstream from site G1 (table 11). The other well in which selenium exceeded the drinking-water standard was at Lakin (site G4). The concentration of selenium in a sample from that site was $12 \mu \mathrm{g} / \mathrm{L}$.

The highest concentrations of selenium measured in all the samples during the study were $45 \mu \mathrm{g} / \mathrm{L}$ at site $\mathrm{T} 1$ and $52 \mu \mathrm{g} / \mathrm{L}$ at site T2 (table 8). These concentrations exceed the U.S. EPA criteria for protection of aquatic life for both chronic and acute exposure (table 5). They also exceed the Colorado standard for chronic exposure but not for acute exposure. The State selenium standards and U.S. EPA criterion for acute exposure were not exceeded at any other surface-water sites (tables 8-10); however, the U.S. EPA criterion for chronic exposure $(5 \mu \mathrm{g} / \mathrm{L})$ was exceeded at four additional sites on the Arkansas River (sites A2, A3, A6, and A7), at three reservoir sites in June (sites R2, R4, and R5), and at one reservoir site in October (site R5).

The only other water-quality standard that was exceeded in any sample was the chronic-exposure aquatic-1ife standard for mercury $(0.1 \mu \mathrm{g} / \mathrm{L}$ in Colorado and $0.012 \mu \mathrm{g} / \mathrm{L}$ in Kansas, table 5). The highest mercury concentrations were detected at the most upstream sites (tables 8 and 9): Pueblo Reservoir (site R1, $0.6 \mu \mathrm{g} / \mathrm{L}$ ), the Arkansas River above Pueblo (site A1, 0.9 $\mu \mathrm{g} / \mathrm{L}$ ), Fountain Creek (site $\mathrm{T} 1,0.5 \mu \mathrm{g} / \mathrm{L}$ ), and Lake Meredith (site R2, $0.6 \mu \mathrm{g} / \mathrm{L})$. Concentrations decreased downstream but exceeded the standard at all stream sites except the most downstream location (site A7, Arkansas River near Deerfield). The source of mercury seems to be upstream from the study area, and the elevated concentrations probably are not caused by irrigation return flow within the study area. The acute-exposure standard $(2.4 \mu \mathrm{g} / \mathrm{L})$ was not exceeded at any site.

Concentration of trace elements, other than selenium and mercury, generally were much lower than the most restrictive standards listed in tables 5 and 6 . The maximum cadmium concentration was $2 \mu \mathrm{g} / \mathrm{L}$, which might have exceeded the aquatic life standard if the hardness was low. The lowest hardness associated with $2 \mu \mathrm{g} / \mathrm{L}$ of cadmium was $270 \mathrm{mg} / \mathrm{L}$ at site A2 (Arkansas River near Nepesta). At this hardness level, the chronic-exposure standard for cadmium is about $2.5 \mathrm{\mu g} / \mathrm{L}$. Lead concentrations were less than analytic 
reporting limits $(5 \mu \mathrm{g} / \mathrm{L})$ in all samples but could have exceeded the aquaticlife standard for chronic exposure if hardness was low. However, the only site where hardness was low enough for the standard to be less than $5 \mu \mathrm{g} / \mathrm{L}$ was site R1 (Pueblo Reservoir), which is upstream from the irrigated area. The maximum concentrations of arsenic, chromium, copper, and zinc in all water samples were no more than 50 percent of the most restrictive standards for these trace elements.

Because data collection for the study occurred during a 4-month period, short-term hydrologic conditions could have had a substantial effect on water quality. To evaluate this effect, historical data from several surface-water sites were compared to data collected during the study. The largest record of data available in the study area was for specific conductance, which can be a surrogate measure of the dissolved-solids concentration in water. The historical distributions of specific-conductance data from eight sites are plotted in figure 12. Values measured at these sites during the study also are shown. At Pueblo Reservoir (site R1) and Lake Meredith (site R2), the June values were about equal to the lower quartile of the historical data, but the October values were as high or higher than the historical maximums.

Specific conductance generally varies inversely with streamflow; therefore, the greater than normal inflow to the study area during 1983-87 (fig. 5) could have diluted specific conductance throughout the study area in the beginning of the sampling period. As inflow to the study area decreased to less than normal during the sampling period, specific conductance could have increased. However, most specific-conductance values for stream samples collected in August were about the same as the historical medians for the stream sites (A1, $\mathrm{T} 1, \mathrm{~T} 2, \mathrm{~A} 2$, and A4). In the Arkansas River near Coolidge (site A6), the value was much less than the historical median. This site is downstream from John Martin Reservoir, from which releases were greater than normal during the study period. These releases could have maintained a dilute condition in the eastern part of the study area, even though inflow at the western end (site A1) was less than normal.

Similar effects can be seen in plots of dissolved-selenium data (fig. 13) for sites with at least eight historical values. Between June and October, selenium concentration at Pueblo Reservoir (site R1) increased from the historical 25 th percentile to the 75 th percentile. Concentrations were about the same as the historical median in the Arkansas River upstream from Pueblo (site A1) and downstream from John Martin Reservoir (site A4) but less than the 25th percentile farther downstream near Coolidge (site A6). In general, the constituent concentrations in samples collected during the study upstream from John Martin Reservoir may be representative of normal conditions, but those in samples collected at downstream sites may be representative of dilute conditions. 


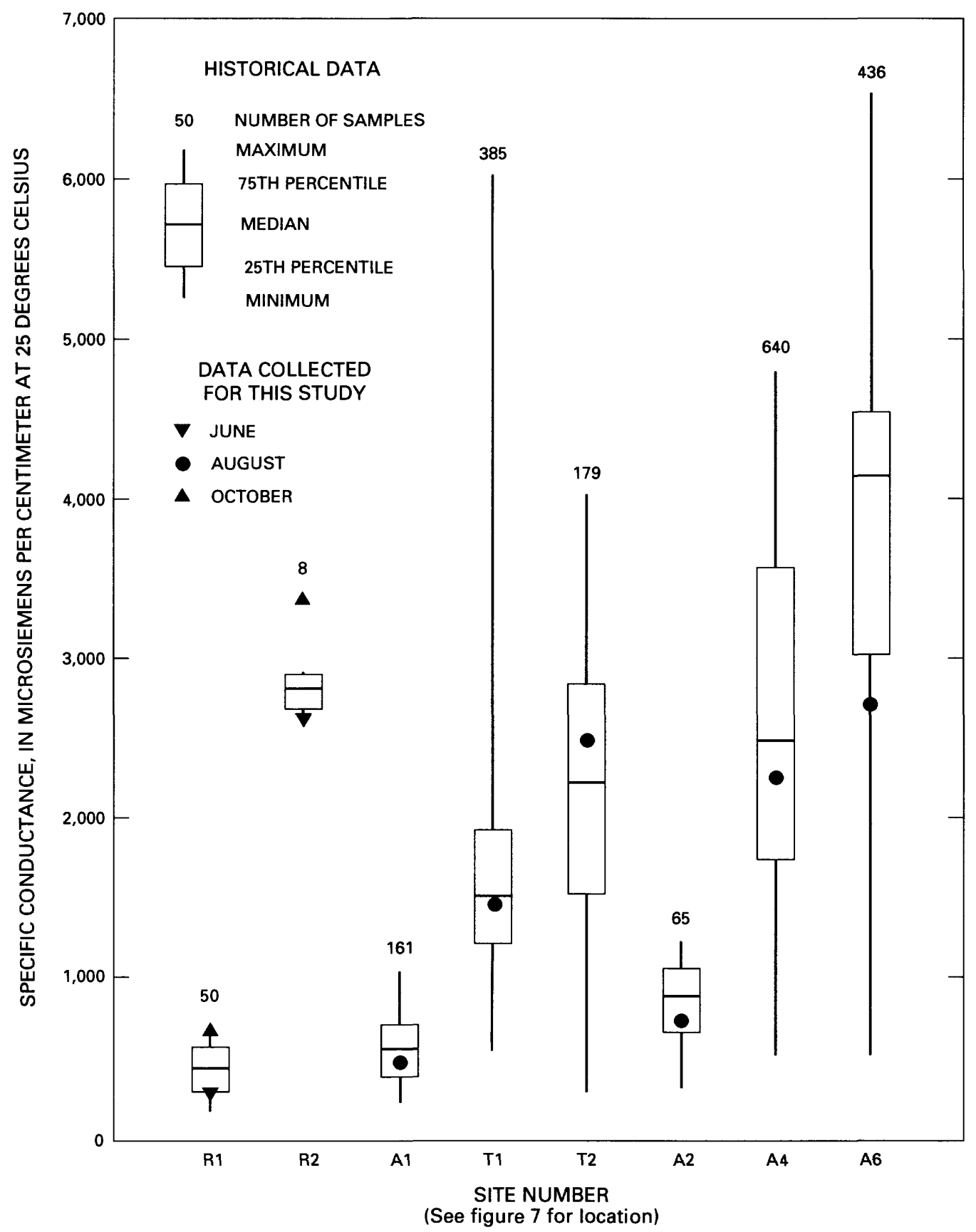

Figure 12.--Historical specific-conductance data and values measured during the study in 1988 . 


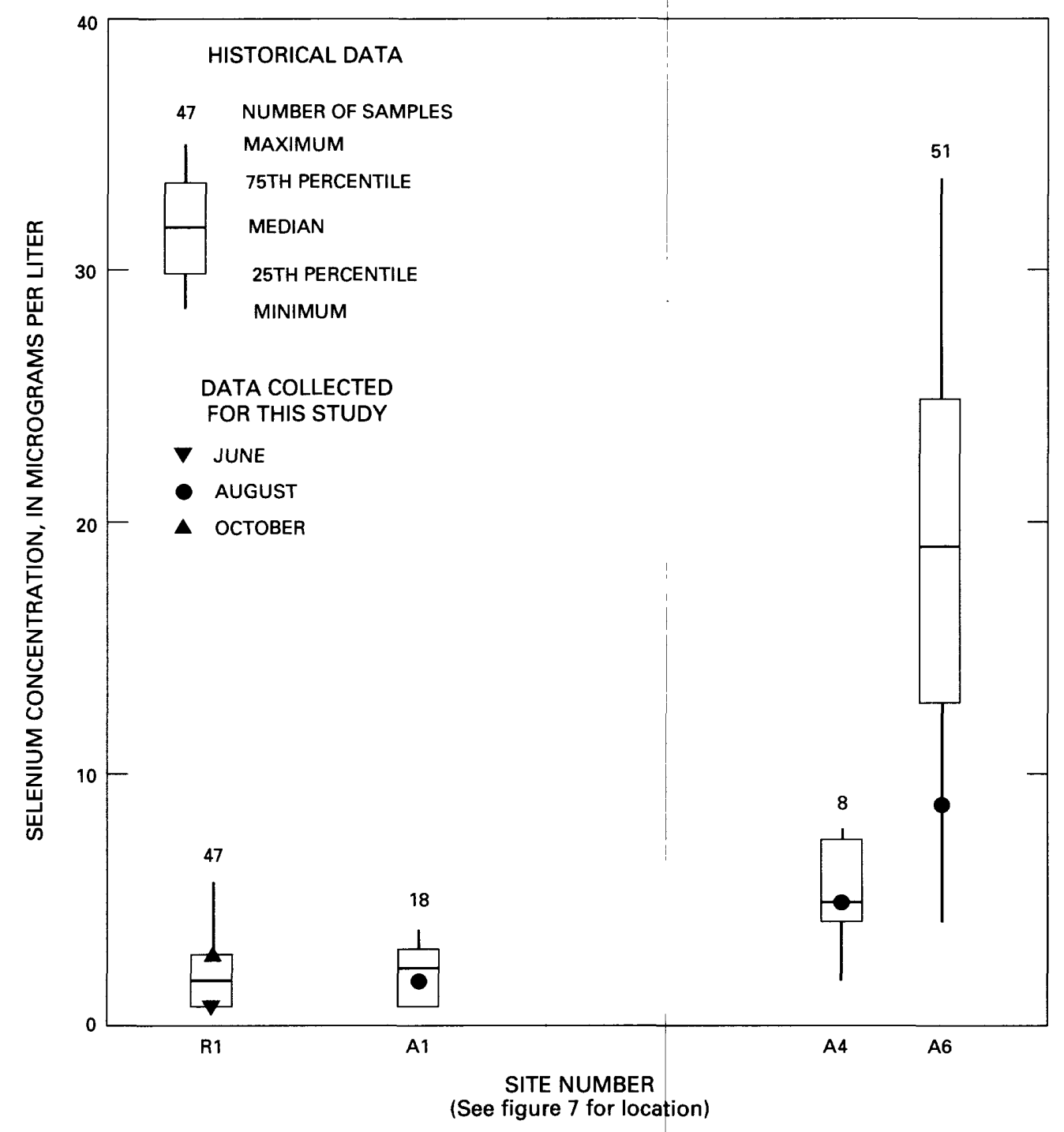

Figure 13.--Historical dissolved-selenium data and concentrations in water samples collected during the study in 1988. 


\section{Bottom Sediment}

Selenium concentrations in the fine fraction of bottom sediment (particle size $<0.062 \mathrm{~mm})$ exceeded the baseline value $(1.4 \mu \mathrm{g} / \mathrm{g}$, table 7$)$ at 5 of the 13 sites (tables 12 and 13 ) where samples were collected. The only stream site that had an elevated concentration was on the St. Charles River (site T2, $2.1 \mu \mathrm{g} / \mathrm{g}$ ), although the concentration in the Arkansas River downstream from John Martin Reservoir (site A4) was almost equal to the baseline value (table 12). All reservoir sites except the Great Plains Reservoirs (site R3) had elevated concentrations, and the concentration at site R3 was equal to the baseline value (table 13). The highest concentrations were in Lake Meredith (site R2, $5.4 \mu \mathrm{g} / \mathrm{g}$ ) and John Martin Reservoir (site R4, $4.2 \mu \mathrm{g} / \mathrm{g}$ ). The high concentration at site $\mathrm{R} 4$ may be additional evidence that selenium is being removed from the water and accumulating in the reservoir. This effect could have caused the decrease in selenium concentration in surface water between sites upstream (site A3) and downstream (site A4) from the reservoir (table 8).

Selenium concentrations in the coarse fraction of bottom sediment (particle size $<2.0 \mathrm{~mm}$ ) were less than concentrations in the fine fraction at all stream sites. At reservoir sites, almost all of the sediment was fine enough to pass through either sieve. Therefore, the fine and coarse fractions were nearly identical, and the selenium concentrations were about equal.

The concentrations of lead and zinc in the fine and coarse fractions of bottom sediment from Pueblo Reservoir (site R1) exceeded baseline values (tables 7 and 13). These elements are among the common constituents of mine drainage and may have been transported into the reservoir from sources upstream from the study area. Copper, mercury, and zinc concentrations exceeded baseline values in the fine fraction of bottom sediment from the Arkansas River near Deerfield (site A7) (table 12). The concentrations of chromium and nickel also were high at this site, although less than the baseline values. No source of these trace metals is known to exist in the vicinity of site $A 7$.

Baseline values were not available for organochlorine pesticides in bottom sediment; however, few concentrations exceeded reporting limits in samples collected at reservoir sites in the study area. Chlordane and DDE were identified at all five reservoir sites (table 13). Maximum concentrations were $2.0 \mu \mathrm{g} / \mathrm{kg}$ for chlordane at Pueblo Reservoir (site R1), near the upstream end of the study area, and $1.0 \mu \mathrm{g} / \mathrm{kg}$ for DDE at Lake McKinney (site R5), near the downstream end. The only occurrence of DDD was at site R1, which is not affected by irrigation drainage from within the study area. Aldrin was identified at one site (Great Plains Reservoirs, site R3), and dieldrin was identified at two sites (R3 and R5). No other pesticides were detected in any sample. 
Concentrations of trace inorganic elements and organic compounds were quantified in a variety of living organisms, principally birds and fish. Bird livers were selected for analysis to determine whether elements or compounds occurred in sufficient quantities to harm the health, reproduction, or survival of birds breeding in the study area. Whole fish were analyzed to determine their contaminant residues and to examine the potential for chemical exposure to fish-eating birds. A limited number of invertebrate and aquatic-plant samples also were collected at some sites. All data are listed by biological matrix in the "Supplemental Data" section (tables 14-20). Geometric-mean values in the data tables were calculated by assigning one-half the reporting limit to samples that had concentrations below the limit of detection. Geometric means were not calculated for elements and matrices with more than one-half of the number of sample concentrations less than detection. The occurrence of elements detected at greater than baseline concentrations is discussed, by element, in the following sections.

\section{Aluminum}

Aluminum was, on average, more concentrated in the livers of killdeer than in livers of either mallards or American coots (tables 14 and 15). The maximum aluminum concentrations in bird samples were $416 \mu \mathrm{g} / \mathrm{g}$ in an adult killdeer liver (table 15) and $1,090 \mu \mathrm{g} / \mathrm{g}$ in the whole body of a juvenile killdeer (table 16), both from Pueblo Reservoir|(site R1). Aluminum concentrations in whole bodies of nestlings or young birds were consistently higher than those in adult livers, but the concentrations in eggs were lower than in livers (table 16). Concentrations of aluminum in livers from four avian species varied from less than 2.90 to $8.24 \mu \mathrm{g} / \mathrm{g}$, and in breast muscles from the same birds, residues varied from less than 2.88 to $23.7 \mathrm{\mu g} / \mathrm{g}$ (table 15). Aluminum concentrations in mallard and American coot samples did not indicate any downstream trend. Data obtained for mallards and American coots at the same reservoirs in June and October were similar between months and species.

Samples from stream sites indicated generally higher concentrations of aluminum in crayfish than in all species of fish collected (table 17). Common carp had the lowest concentrations among fish. For carp samples from stream sites, the peak aluminum concentration occurred at Lamar (site A5). The maximum concentration in crayfish occurred at La Junta (site A3). A general increase in aluminum concentrations from upstream to downstream sites was detected in shiners; the highest concentration occurred at Deerfield (site A7). Aluminum concentrations in $f$ ish collected from reservoirs during June and October were variable (table 18). The maximum concentration of aluminum in fish was $3,200 \mu \mathrm{g} / \mathrm{g}$ in gizzard shad from the Great Plains Reservoirs (site R3), and the minimum was less than $3 \mu \mathrm{g} / \mathrm{g}$ in one species from the Great Plains Reservoirs and two species from John Martin Reservoir (site R4). Using common carp for comparison, the only fish species collected at most stream and reservoir sites, aluminum concentrations were nearly four times higher in the reservoir fish (tables 17 and 18). Consistent downstream trends were not apparent for fish samples from reservoirs. 
Filamentous algae and pondweed samples from the reservoir sites had particularly high concentrations of aluminum (table 19). The highest concentrations were $18,200 \mu \mathrm{g} / \mathrm{g}$ in algae and $4,220 \mu \mathrm{g} / \mathrm{g}$ in pondweeds from Lake Meredith (site R2). Progressively lower aluminum concentrations occurred in aquatic plants, whole fish, whole avian juveniles, and adult avian livers.

Aluminum concentrations detected in filamentous algae from Pueblo Reservoir (site R1), Lake Meredith (site R2), and John Martin Reservoir (site R4) may be a hazard to young herbivorous birds, such as American coots. Mallard ducklings exposed to about $11,000 \mu \mathrm{g} / \mathrm{g}$ aluminum $(10,000 \mathrm{\mu g} / \mathrm{g}$ wet weight) in the diet experienced stunted growth and high rates of mortality, and those exposed to about $5,500 \mu \mathrm{g} / \mathrm{g}$ aluminum $(5,000 \mu \mathrm{g} / \mathrm{g}$ wet weight) in the diet experienced stunted growth and altered behavior (Sparling, 1990). A concentration of $416 \mathrm{\mu g} / \mathrm{g}$ (dry weight) in a killdeer liver from Pueblo Reservoir (site R1) (table 15) possibly could be considered elevated. The source of potential aluminum contamination in the study area is not known.

\section{Arsenic}

All samples of avian liver and breast muscle had less than $0.54 \mu \mathrm{g} / \mathrm{g}$ total arsenic (tables 14-16). All but one sample of juveniles and eggs had less than the detection limit of $0.2 \mu \mathrm{g} / \mathrm{g}$ arsenic; a whole juvenile mallard had $2.3 \mu \mathrm{g} / \mathrm{g}$ arsenic (table 16).

The maximum concentration of arsenic in fish from stream sites was $1.24 \mathrm{\mu g} / \mathrm{g}$ in shiners at Deerfield (site A7) (table 17). The maximum in fish from reservoirs was $2.1 \mu \mathrm{g} / \mathrm{g}$ in a small-mouth bass sample collected at Pueblo Reservoir (site R1) in June (table 18). The maximum concentration in crayfish was $2.85 \mathrm{\mu g} / \mathrm{g}$ in a sample from the Arkansas River near Coolidge (site A6) (table 17). Arsenic concentrations in five fish species collected at the five study reservoirs were higher in June than they were in October in 8 of 10 instances where the species was collected both times. Ten of 59 total fish samples collected for the study had arsenic concentrations exceeding the 85 th percentile $(0.22 \mu \mathrm{g} / \mathrm{g}$ wet weight; $0.76 \mu \mathrm{g} / \mathrm{g}$ dry weight) established by a national survey (Lowe and others, 1985); eight of these samples were from reservoir sites.

The maximum concentration of arsenic in aquatic plants was $37.2 \mu \mathrm{g} / \mathrm{g}$ in a sample of filamentous algae from Lake Meredith (site R2) (Table 19). This concentration is less than the $115 \mu \mathrm{g} / \mathrm{g}$ dry weight (approximated using 13-percent moisture) of arsenic, which when incorporated into the diet delayed growth in mallard ducklings (Camardese and others, 1990).

In general, arsenic concentrations were highest in aquatic plants, followed by crayfish, reservoir fish, stream fish, and avian livers, eggs or young. The source of arsenic is not known; however, mining activity occurs upstream from the study area, and industrial activities occur within the study a rea. 
Cadmium was less than the reporting limit $(0.19 \mu \mathrm{g} / \mathrm{g})$ in all waterfowl breast-muscle samples and did not exceed $3.99 \mu \mathrm{g} / \mathrm{g}$ in liver samples (table 15). Cadmium was detected in only 1 of 10 samples of whole bodies or livers of juvenile birds and in none of 9 samples of bird eggs (table 16). Pathological changes have been identified in mallards that had cadmium concentrations of almost $100 \mathrm{\mu g} / \mathrm{g}$ in their livers (White and Finley, 1978).

Concentrations of cadmium in fish did not exceed any reporting limits (0.16-3 $\mathrm{\mu g} / \mathrm{g}$ dry weight) (tables 17 and 18). The 85th percentile established by a national survey (Lowe and others, 1985), $0.06 \mu \mathrm{g} / \mathrm{g}$ wet weight $(0.21 \mu \mathrm{g} / \mathrm{g}$ dry weight), could not be used as a baseline because it was below most of the reporting limits used for this study.

The highest concentration of cadmium in aquatic plants was $0.94 \mu \mathrm{g} / \mathrm{g}$ in a sample of algae from Lake Meredith (site R2) (table 19). Concentrations of cadmium in aquatic plants or other biota from the study area are not considered a problem.

\section{Copper}

Copper concentrations in the livers of mallards generally exceeded those in American coots and killdeer, in that order, collected at reservoir sites (tables 14 and 15). No downstream trend was evident for any of these three species, and seasonal differences were not obvious; however, the highest concentrations in mallards and coots occurred in fall. The geometric mean copper concentration in livers of seven mallards, blue-winged teal, and wood duck was twice the concentration in breast muscle from the same birds $(44 \mu \mathrm{g} / \mathrm{g}$ in liver and $22 \mu \mathrm{g} / \mathrm{g}$ in breast muscle), but in six American coots the tissue copper concentrations were nearly equal $(33 \mu \mathrm{g} / \mathrm{g}$ in liver and $37 \mu \mathrm{g} / \mathrm{g}$ in muscle) (table 15). The maximum concentration for birds was $255 \mu \mathrm{g} / \mathrm{g}$ in an eared grebe liver from Lake Meredith (site R2) (table 15). Copper concentrations in adult avian livers were higher than in juvenile livers, eggs, or whole nestlings (tables 14-16) but were mostly less than the $192.7 \mu \mathrm{g} / \mathrm{g}$ (dry weight) in livers of domestic ducks that showed no visible effects on a diet of up to $27 \mathrm{\mu g} / \mathrm{g}$ copper for 15 weeks (Beck, 1961). The maximum copper concentration in juveniles was $64.1 \mu \mathrm{g} / \mathrm{g}$ in a mallard liver from Lake McKinney (site R5) and $23.4 \mu \mathrm{g} / \mathrm{g}$ in the liver of a double-crested cormorant from John Martin Reservoir (site R4).

Copper concentrations in fish samples from streams could not be compared with those in fish from reservoirs because of differences in the reporting limits (tables 17 and 18). The highest concentration detected in stream samples was $15.4 \mu \mathrm{g} / \mathrm{g}$, in common carp from the Arkansas River near Deerfield (site A7). The 85th-percentile baseline for copper concentrations in fish is $0.90 \mu \mathrm{g} / \mathrm{g}$ wet weight and $3.10 \mu \mathrm{g} / \mathrm{g}$ dry weight (Lowe and others, 1985). This baseline concentration was equaled or exceeded in 24 of $42 \mathrm{fish}$ samples collected from reservoirs (table 18). Concentrations in similar fish species collected at two or more reservoir sites indicated no consistent downstream trend (table 18). The reporting limit for copper in fish from stream sites was higher than the baseline concentration (table 17). 
Copper concentrations in crayfish were about one order of magnitude higher than in fish from stream sites; the maximum concentration was $205 \mu \mathrm{g} / \mathrm{g}$ in a sample from the Arkansas River near La Junta (site A3). Two invertebrate samples from reservoir sites had copper concentrations of 73.1 and $30.9 \mu \mathrm{g} / \mathrm{g}$, which were higher than the maximum concentration in reservoir fish $(7.4 \mu \mathrm{g} / \mathrm{g})$ (table 18).

Aquatic plants generally had lower concentrations of copper than avian livers, but the concentrations were higher than in fish. The maximum was $37.2 \mathrm{\mu g} / \mathrm{g}$ in a filamentous algae sample from Lake Meredith (site R2) (table 19).

The source of copper is not known; however, mining occurs upstream from the study area, and industries and municipalities discharge their effluents into the river upstream from and within the study area.

\section{Mercury}

Mercury concentrations in 10 of 70 avian liver samples and in 1 of 13 avian breast-muscle samples (tables 14 and 15 ) were greater than $1.0 \mu \mathrm{g} / \mathrm{g}$, a concentration that could be considered elevated (Ohlendorf and others, 1978). Livers from blue-winged teal were the most contaminated; the maximum mercury concentration was $4.64 \mathrm{\mu g} / \mathrm{g}$ in a sample collected during October from Pueblo Reservoir (site R1). This concentration is within the range of mercury in livers of mallards that were fed $0.5 \mu \mathrm{g} / \mathrm{g}$ in their diet (Heinz, 1980). Concentrations in juvenile livers, whole nestlings, and eggs generally were lower than in adult livers (table 16); however, concentrations in black-crowned night heron eggs from Lake Meredith (site R2) were similar to those in adults livers. Maximum concentrations for livers and eggs were less than the concentrations associated with reproductive impairment (Finley and Stendell, 1978).

Mercury concentrations in fish and aquatic plants also were low (tables 17-19). Only 3 of 59 fish samples from stream sites had a mercury concentration greater than the $0.1 \mu \mathrm{g} / \mathrm{g}$ wet weight (about $0.34 \mu \mathrm{g} / \mathrm{g}$ dry weight using 71 percent moisture) proposed to protect avian predators (Eisler, 1987), and only 1 of these exceeded the 85 th percentile baseline of $0.18 \mu \mathrm{g} / \mathrm{g}$ wet weight $(0.62 \mu \mathrm{g} / \mathrm{g}$ dry weight) (Lowe and others, 1985).

In general, concentrations of mercury were highest in avian livers collected during October and in stream fish. Concentrations were intermediate in avian livers collected in June and in reservoir fish, and they were lowest in aquatic plants.

Selenium

Among all biological samples collected for this study, selenium concentrations were highest in livers of birds. Among three avian species collected at most reservoir sites, concentrations generally were higher in killdeer than they were in mallards or American coots (tables 14 and 15). Selenium concentrations in all three species generally were lowest at the downstream end of the study area. The highest individual and geometric mean concentrations in 
mallards and killdeer occurred in samples from Pueblo Reservoir (site R1). The highest concentrations in American coots occurred in samples from Lake Meredith (site R2). The overall maximum selenium concentration was $56 \mu \mathrm{g} / \mathrm{g}$ in the liver of a black-necked stilt from Lake Meredith (table 14). Concentrations of selenium in whole juveniles, juvenile livers, nestlings, and eggs (table 16) generally were lower than in adult livers. The geometric-mean selenium concentration was $6.4 \mu \mathrm{g} / \mathrm{g}$ (table 16) in eggs of black-crowned night herons from Lake Meredith and $5.9 \mu \mathrm{g} / \mathrm{g}$ in eggs of blackbirds from John Martin Reservoir.

Because few of the same avian species were collected at all reservoir sites, a general frequency analysis, disregarding species, was used to assess selenium in adult livers, the predominant avian submatrix. The criterion used was $20 \mu \mathrm{g} / \mathrm{g}$ (dry weight), double the concentration proposed by the U.S. Fish and Wildlife Service (1990) to be indicative of selenium residues greater than background. Liver samples with at least $20 \mu \mathrm{g} / \mathrm{g}$ selenium numbered 7 of 8 at Pueblo Reservoir (site R1), 11 of 15 at Lake Meredith (site R2), 3 of 3 at the Great Plains Reservoirs (site R3), and 3 of 4 at John Martin Reservoir (site R4), but only 2 of 11 at Lake McKinney (site R5). Because samples of species were not equally represented at all sites, differences attributable to species may preclude meaningful site comparisons.

Of the 70 liver samples from 9 species collected in June and October, 10 samples from adults of 4 species had selenium concentrations exceeding or equaling $30 \mu \mathrm{g} / \mathrm{g}$, a concentration usually associated with biological risk (U.S. Fish and Wildlife Service, 1990). Five of these 10 samples were from killdeer. Because the killdeer liver samples were composites from three adults collected during the breeding season, these data give strong implications of possible harmful effects of selenium on killdeer in some parts of the study area.

The frequency of avian liver samples with at least $20 \mu \mathrm{g} / \mathrm{g}$ selenium was 26 of 41 in June and only 4 of 29 in October. This analysis indicates that birds found at the study reservoirs tend to be more contaminated in the spring than in the fall. These data support a hypothesis that residency during breeding results in a greater degree of contamination than does transiency during the fall.

Samples of liver and breast muscle from individual birds of four species collected in October revealed a varying pattern of liver-to-muscle ratios (table 15). The median ratio for five mallards was $3.0(0.48-4.6)$, and for six American coots it was $2.1(0.18-6.8)$. For all 13 paired samples, including 4 species, the median ratio was 2.3 . The data are meager; therefore, they cannot be examined for the importance of variables, including season, species, age, or sex.

The range of selenium concentrations in adult avian livers collected during this study overlaps the 2.0 to $43 \mu \mathrm{g} / \mathrm{g}$ range reported for coot livers from the Ouray National Wildlife Refuge in Utah (Stephens and others, 1988). Mallards in the middle Arkansas River basin were almost as contaminated with selenium as American coots from the Ouray National Wildlife Refuge, and killdeer generally were more contaminated. Average selenium concentrations in killdeer livers from three of the five reservoir sites in this study exceeded 
the $30.9 \mu \mathrm{g} / \mathrm{g}$ average for coot livers from the Kesterson National Wildlife Refuge in California (Ohlendorf and others, 1986). Selenium concentrations were greater in the livers of many birds in the middle Arkansas River Basin, than in the livers of mallards in laboratory experiments (Heinz and others, 1987), in which abnormal numbers of embryos died $(9.0 \mathrm{\mu g} / \mathrm{g}$ dry weight for females) or were deformed $(16.2 \mu g / g$ dry weight for females).

Selenium analysis was performed on a limited number of eggs, whole nestlings, juveniles, and livers of juveniles (table 16). Concentrations in eggs of three species were elevated (greater than $3 \mu \mathrm{g} / \mathrm{g}$ dry weight; U.S. Fish and Wildlife Service, 1990) but not enough to indicate reproductive impairment (greater than $20 \mu \mathrm{g} / \mathrm{g}$ dry weight; U.S. Fish and Wildlife Service, 1990). Whole nestlings of yellow-headed blackbirds from Lake Meredith (site R2) had a geometric-mean selenium concentration of $16 \mu \mathrm{g} / \mathrm{g}$ dry weight. This concentration is only slightly less than the $20 \mu \mathrm{g} / \mathrm{g}$ selenium criteria for reproductive impairment and may indicate a need for concern at this sampling site.

Selenium concentrations in fish from the streams were not consistently high or low relative to location; however, the only selenium concentrations greater than $10 \mu \mathrm{g} / \mathrm{g}$ occurred in fish samples from the tributaries and the more downstream locations on the Arkansas River (tables 17 and 18). The maxiumum concentration in stream fish was $18.5 \mu \mathrm{g} / \mathrm{g}$ in a common carp sample from Lamar (site A5), and the maximum concentration in reservoir fish was $20 \mathrm{\mu g} / \mathrm{g}$ in a composite sample of gizzard shad from John Martin Reservoir (site R4).

Because the same species of fish were not collected at all sites, optimum comparisons among sites, between stream and reservoir sites, and between seasons were not possible. As an alternative method of comparison, the frequency of fish samples of all species having a selenium concentration of at least $12 \mu \mathrm{g} / \mathrm{g}$ was counted for each site. Concentrations greater than $12 \mu \mathrm{g} / \mathrm{g}$ dry weight selenium in whole-body fish have been associated with reproductive failure by bluegills (Gillespie and Baumann, 1986). This frequency analysis indicated that fish samples from stream sites, Pueblo Reservoir (site R1), and the Great Plains Reservoirs (site R3) had a relatively low incidence of elevated selenium concentrations. The frequencies of samples with concentration greater than or equal to the $12 \mu \mathrm{g} / \mathrm{g}$ criterion were 3 of 17 for stream sites, 0 of 12 for site R1, and 1 of 9 for site R3; averaging about 10 percent. Comparable frequencies were five of seven samples from Lake Meredith (site R2), eight of eight samples from John Martin Reservoir (site R4), and four of six samples from Lake McKinney (site R5), averaging about 79 percent. When the data for June and October at reservoir sites are separated and sites are combined, the seasonal occurrences of samples that had selenium concentrations greater than or equal to $12 \mu \mathrm{g} / \mathrm{g}$ were about 40 percent in both seasons ( 9 of 20 in June and 9 of 22 in October). Results of this analysis indicate that fish at reservoir sites $R 1$ and $R 3$ may have less selenium contamination than the fish at reservoir sites $R 2$, R4, and $R 5$. The pattern in fish indicates the occurrence of progressively greater selenium contamination downstream, whereas the reverse pattern was indicated for birds. 
Fish samples from Lake Meredith (site R2), John Martin Reservoir (site R4), and Lake McKinney (site R5) generally had the highest selenium concentrations at reservoir sites. Fish samples from the two tributaries (sites $\mathrm{T} 1$ and $\mathrm{T} 2$ ) and from the Arkansas River below John Martin Reservoir (site A4) and at Lamar (site A5) generally had the highest selenium concentrations at stream sites. Selenium concentrations in fish samples were greater than the $85 \mathrm{th}$ percentile $(0.71 \mu \mathrm{g} / \mathrm{g}$ wet weight, $2.45 \mu \mathrm{g} / \mathrm{g}$ dry weight) established by a national survey (Lowe and others, 1985). Selenium in 7 of $17 \mathrm{fish}$ samples from stream sites and 25 of 42 fish samples from reservoir sites exceeded the maximum concentration $(8.52 \mu \mathrm{g} / \mathrm{g} \mathrm{dry}$ weight) determined in that survey. Forty-nine of the 59 fish samples contained selenium exceeding the $4 \mathrm{\mu g} / \mathrm{g}$ dry weight in the diet that has been proposed to protect birds (U.S. Fish and Wildlife Service, 1990). Fifty-two percent of the fish samples contained selenium concentrations that equaled or exceeded the dietary concentration of selenium ( $10 \mu \mathrm{g} / \mathrm{g}$ wet weight; about $9 \mu \mathrm{g} / \mathrm{g}$ dry weight) determined to harm the embryos of mallards (Heinz and others, 1987).

Selenium concentrations in aquatic plants were lower than in avian samples and fish (table 19). The maximum detected concentration was $14 \mu \mathrm{g} / \mathrm{g}$ in algae from Lake Meredith in Colorado. The selenium concentration in two samples of aquatic plants exceeded the dietary concentration that was determined to increase embryonic mortalities, and deformities in mallards $(10 \mu \mathrm{g} / \mathrm{g}$ wet weight, about $9 \mu \mathrm{g} / \mathrm{g}$ dry weight; Heinz and athers, 1987). Seven of the eight aquatic plant samples had selenium concentrations exceeding the permissible dietary level for breeding birds $(4 \mu \mathrm{g} / \mathrm{g}$ dry weight) (U.S. Fish and Wildlife Service, 1990).

In general, selenium concentrations in biota were highest in avian livers and were progressively lower in whole fish, young birds or eggs, and aquatic plants. No evidence of deformity or reproductive failure was observed in any bird or fish species during sample collection; however, the sampling program was not designed specifically to assess reproduction or to determine the extent of embryonic deformities.

\section{Zinc}

The maximum zinc concentration in an adult avian sample was $322 \mu \mathrm{g} / \mathrm{g}$ in an American coot liver from Lake Meredith (site R2, table 15). Geometric-mean concentrations generally were higher than $100 \mu \mathrm{g} / \mathrm{g}$ in mallards and American coots and less than $100 \mathrm{\mu g} / \mathrm{g}$ in killdeer (tables 14 and 15). Concentrations in American coot livers collected in October exceeded those collected in June. No downstream trend was apparent. Zinc concentrations in whole nestlings and juvenile livers were similar to those in adult livers, but egg samples tended to have the lowest concentrations of all avian sample types (table 16).

Breast muscles of four species collected in October had zinc concentrations ranging from about one-fifth to one-half of those in the livers of the same birds (table 15). Zinc concentrations in samples of breast muscle ranged from 41.4 to $74.9 \mu \mathrm{g} / \mathrm{g}$, whereas liver samples had zinc concentrations that ranged from 53.1 to $322 \mu \mathrm{g} / \mathrm{g}$. 
Zinc concentrations in fish from stream and reservoir sites were similar (tables 17 and 18). The maximum zinc concentration in stream fish was $330 \mu \mathrm{g} / \mathrm{g}$ in a common carp sample from the Arkansas River near Nepesta (site A2). Concentrations in fish had no distinguishable downstream trend. The highest concentrations in crayfish were in samples from the upstream sites. The maximum concentration in fish from reservoirs was $401 \mu \mathrm{g} / \mathrm{g}$ in a common carp sample from the Great Plains Reservoir system (site R3) (table 18). Zinc concentrations in 23 of 59 total fish samples (tables 17 and 18) exceeded the $85 \mathrm{th}$ percentile $(40.1 \mu \mathrm{g} / \mathrm{g}$ wet weight, $138.2 \mathrm{\mu g} / \mathrm{g}$ dry weight) established by a national survey (Lowe and others, 1985). The 23 samples include all 15 of the common carp samples from reservoir and stream sites, all 6 shiner samples, and both long-nosed dace samples from stream sites. Concentrations in common carp were highest, which is consistent with a recent finding that carp tend to concentrate zinc more than other species of fish (Stephens and others, 1988).

Zinc concentrations in aquatic plants were lower than in fish or avian livers. The maximum zinc concentration was $71.2 \mu \mathrm{g} / \mathrm{g}$ in a filamentous algae sample from Lake Meredith (site R2) (table 19).

\section{Organochlorine Pesticides}

Composite samples of 3 common carp each from stream sites A2, A3, A5, and $A 7$ were analyzed for 26 organochlorine compounds, including pesticides and PCB's. These were splits of the same carp samples, listed in table 17, that were analyzed for inorganic constituents. The only organochlorine compound detected in these four samples was $p, p^{\prime}-D D E(0.08 \mu \mathrm{g} / \mathrm{g})$ in a common carp sample from the Arkansas River at LaJunta (site A3).

Additional biota samples from four reservoir sites (splits of samples analyzed for inorganic constituents) also were analyzed for organochlorine pesticides and PCB's. Eight organochlorine pesticides, among the 26 organochlorine compounds analyzed, were detected in some samples of livers and eggs of birds and fish collected from reservoir sites in June (table 20). Concentrations of all compounds in birds and fish generally were low (less than or equal to $2.3 \mu \mathrm{g} / \mathrm{g}$ ) and within the range of background concentrations (Fleming and others, 1983; Schmitt and others, 1985). Killdeer and black-crowned night herons, both migratory species, had more kinds of detectable organochlorine compounds than the other species, and $p, p^{\prime}-D D E$ was the compound detected most frequently. The highest concentration of $p, p^{\prime}-D D E$ was $2.3 \mu g / g$ (wet weight) in one composite sample of three killdeer livers from John Martin Reservoir (site R4).

\section{Correlation Among Substrates}

Water chemistry seems to be a good indicator of stream reaches and reservoirs that are affected by runoff from marine-shale lands in the study area. In particular, elevated concentrations of sulfate, boron, and uranium are associated with this effect. The greatest increases in sulfate, boron, and uranium concentrations in the Arkansas River occur in reaches where irrigation return flow is known to comprise a large portion of the streamflow during part of the year. Subsurface drainage from unlined canals and laterals 
and from irrigated fields and pastures on land underlain by marine shale may dissolve mineral salts from weathered, unconsolidated shale material and transport the solutes to the river. Similar solute transport mechanisms previously have been identified in the Colorado River basin (Iorns and others, 1965).

Selenium concentration also increases in the Arkansas River reaches that seem to be affected by irrigation drainage, but unlike sulfate, boron, and uranium, the concentration of selenium decreases as the river passes through John Martin Reservoir. Selenium concentration in bottom sediment from the reservoir was much higher than concentrations in the river bottom sediment upstream or downstream. A reductive process in the reservoir may be removing selenium from the water and incorporating it into the sediment. This process seems to have a minimal effect on sulfate, boron, and uranium concentrations. A similar process may be occurring in Lake Meredith. The concentration of selenium in the fine fraction of bottom sediment at this site was the highest determined in the study area $(5.4 \mu \mathrm{g} / \mathrm{g})$, but the concentration in the lake water was low $(4-7 \mu \mathrm{g} / \mathrm{L})$.

Few obvious relations could be identified between concentrations of selenium in abiotic and biotic matrices. Selenium concentrations in reservoir fish generally increased in a downstream direction, but concentrations in avian livers decreased. Concentrations of selenium in fish and bottom sediment generally were higher at reservoir sites than at stream sites, but concentrations in water were higher at stream sites than at reservoir sites. Selenium concentrations in water samples from reservoir sites were correlated with selenium concentrations in 18 composite samples of whole common carp and gizzard shad collected during the same month (fig. 14). The general relation is defined by the regression equation:

$$
\operatorname{Se}(\text { fish })=8.80+0.89 \mathrm{Se}(\text { water })
$$

where $\operatorname{Se}(\mathrm{fish})=$ selenium concentration in whole fish, in micrograms per gram dry weight, and

$$
\begin{gathered}
\mathrm{Se}(\text { water })=\text { selenium concentration in reservoir water samples, in } \\
\text { micrograms per liter. }
\end{gathered}
$$

The regression was statistically significant $(p=0.03)$, the standard error was $4.4 \mu \mathrm{g} / \mathrm{g}$, and the coefficient of determination $\left(r^{2}\right)$ was 0.27 . No significant relation was identified between selenium concentrations in sediment and bottom-feeding common carp from reservoirs.

Other than selenium, the only trace elements that had elevated concentrations were mercury in water; copper, lead, mercury, and zinc in bottom sediment; and aluminum, arsenic, copper, and zinc in biota. The source of lead, mercury, and zinc may be mine drainage upstream from the study area. 


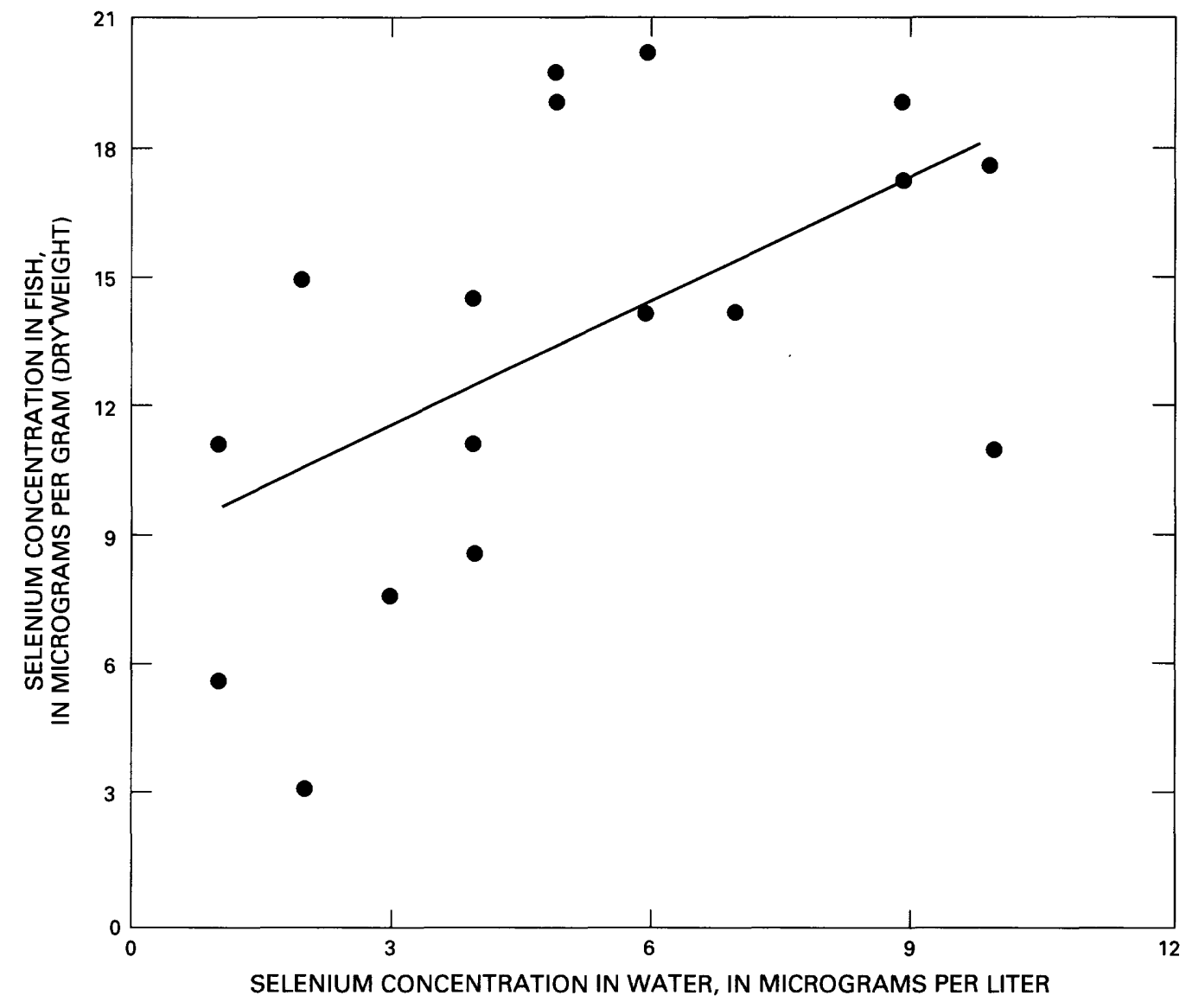

Figure 14.--Relation of selenium concentrations in reservoir water samples to concentrations in common carp and gizzard shad at reservoir sites.

\section{SUMMARY}

During the last several years, there has been increasing concern about the quality of irrigation drainage and its potentially harmful effects on human health, fish, and wildlife. The U.S. Department of the Interior started a program in late 1985 to identify the nature and extent of irrigation-induced waterquality problems that might exist in the Western United States. Initially, 20 locations in 13 States were selected for reconnaissance-level field investigations. Nine of these investigations were completed during 1986-87, and the remaining 11, including an investigation in the middle Arkansas River basin in Colorado and Kansas, were initiated in 1988. All investigations were made by study teams consisting of scientists from the U.S. Geological Survey, the U.S. Fish and Wildlife Service, and the U.S. Bureau of Reclamation. 
The middle Arkansas River basin was selected for investigation primarily because high concentrations of selenium, known to be present in irrigation drainage, previously had been detected at water-quality monitoring sites in the basin. The U.S. Bureau of Reclamation operates the Fryingpan-Arkansas Project in Colorado, which supplies supplemental domestic and irrigation water in the basin. Although no national wildlife refuges exist in the basin, several reservoirs are managed by the State of Colorado for recreational fishing and hunting. Reservoirs in the basin also are used extensively by migratory waterbirds. The federally endangered interior least tern and the federally threatened piping plover nest at two of these reservoirs, and the federally endangered bald eagle winters in the basin.

The study area consisted of the Arkansas River valley from Pueblo Reservoir, in Colorado, to Garden City, Kans. Although the area is semiarid, the predominant land use is agricultural. Extensive acreage is irrigated, primarily along the Arkansas River and its tributaries and near off-channel reservoirs. Some irrigated soils originated from outcrops of marine shale formations under climatic conditions that could result in accumulation of selenium and other trace elements.

The predominant surface-water uses in the middle Arkansas River basin are irrigation and recreation. Reservoirs in the basin are among the most popular in Colorado for boating and fishing. Ground water in the river-valley alluvium is used for domestic supply by several towns in the basin. The Arkansas River also may provide recharge water to the Ogallala Formation, from which domestic supplies are obtained at Garden City, Kans., and other towns downstream from the study area.

Samples of water, bottom sediment, and biota were collected at 14 surfacewater sites in the basin: 7 sites on the Arkansas River, 2 sites on tributary streams, and 5 sites on reservoirs. Ground-water samples were collected from five municipal wells completed in the river-valley alluvial aquifer. During the study, the hydrology and water chemistry in the study area probably were affected by greater than normal runoff for the 5 previous years.

Concentrations of sulfate, boron, and uranium in water indicate that drainage from irrigated land underlain by marine shale affects the Arkansas River between La Junta, Colo., and Deerfield, Kans; two tributary streams in the vicinity of Pueblo, Colo.; and several off-channel reservoirs. Selenium was the only inorganic trace constituent associated with irrigation drainage that was found at elevated concentrations in water, bottom sediment, and biota. Organochlorine pesticides concentrations were low in all matrices and were less than levels of biological concern.

Selenium concentrations in surface water ranged from $1 \mu \mathrm{g} / \mathrm{L}$, in Pueblo Reservoir near the upstream end of the study area in Colorado, to $52 \mu \mathrm{g} / \mathrm{L}$ in the St. Charles River near Vineland, Colo. The maximum concentration in ground water in alluvium was $29 \mu \mathrm{g} / \mathrm{L}$ at Las Animas, Colo. The State standard and the U.S. Environmental Protection Agency maximum contaminant level for selenium in domestic-water supply $(10 \mu \mathrm{g} / \mathrm{L})$ were exceeded at three stream sites and three ground-water sites. State aquatic-life standards and the U.S. Environmental Protection Agency criterion for acute exposure to selenium were not exceeded at any sites on the Arkansas River or in any reservoirs. However, the 
Colorado standard for chronic exposure and the U.S. Environmental Protection Agency criterion for chronic and acute exposure were exceeded in two tributary streams. The U.S. Environmental Protection Agency criterion for chronic exposure was exceeded at four sites on the Arkansas River and in three reservoirs.

Elevated concentrations of selenium in bottom sediment occurred at four of five reservoir sites and at one tributary site. The maximum detected concentration of selenium was $5.4 \mu \mathrm{g} / \mathrm{g}$ in Lake Meredith in Colorado.

Among bird species collected during June 1988 at reservoirs, geometricmean selenium concentrations in livers were highest in killdeer (9.9-42 $\mu \mathrm{g} / \mathrm{g})$, intermediate in mallards $(9.7-24 \mu \mathrm{g} / \mathrm{g})$, and lowest in American coots (12.1-15 $\mu \mathrm{g} / \mathrm{g})$. The maximum detected selenium concentration $(56 \mu \mathrm{g} / \mathrm{g}$ ) was in the liver of a single black-necked stilt from Lake Meredith in Colorado. Concentrations of selenium in some species were similar to those reported at contaminated sites at the Ouray National Wildlife Refuge in Utah and the Kesterson National Wildlife Refuge in California and exceeded the concentration associated with decreased reproduction.

The maximum selenium concentration detected in fish from stream sites was $18.5 \mathrm{\mu g} / \mathrm{g}$ in a sample of common carp from the Arkansas River near Lamar, Colo., and in fish from reservoir sites it was $20 \mathrm{\mu g} / \mathrm{g}$ in a sample of gizzard shad from John Martin Reservoir in Colorado. Five species of $f$ ish in the Arkansas River had selenium concentrations ranging from 2.1 to $18.5 \mu \mathrm{g} / \mathrm{g}$, and three species in the tributaries had selenuim concentrations ranging from 3.6 to $16.9 \mu \mathrm{g} / \mathrm{g}$. Thirteen species of $\mathrm{fish}$ in the reservoirs had selenium concentrations ranging from 2.2 to $20 \mu \mathrm{g} / \mathrm{g}$. All but 3 of the 59 total fish samples exceeded the $85 \mathrm{th}$-percentile national baseline for selenium in fish $(2.45 \mu \mathrm{g} / \mathrm{g}$ dry weight), and 21 of the samples had concentrations exceeding the range associated with reproductive failure in bluegill. About one-half of the samples had selenium concentrations that exceeded the dietary concentration known to increase the rate of mortalities and deformities in mallard embryos.

The maximum concentration of selenium in aquatic plants was $14 \mu \mathrm{g} / \mathrm{g}$ dry weight in algae from Lake Meredith in Colorado. Concentrations in two samples of aquatic plants exceeded the dietary concentration $(10 \mu \mathrm{g} / \mathrm{g}$ wet weight, about $9 \mu \mathrm{g} / \mathrm{g}$ dry weight) known to decrease avian reproduction or harm embryos.

Selenium concentratons in fish collected from reservoir sites were positively correlated to selenium concentrations in the reservoir water. No other relations between abiotic and biotic matrices were identified.

Elevated concentrations of aluminum, arsenic, copper, lead, mercury, and zinc also were determined in at least one matrix. The source of lead, mercury, and zinc may be mine drainage upstream from the study area.

Eight organochlorine pesticides were detected in some samples of bird livers and eggs and in fish from the reservoirs. All concentrations were within the ranges of reported background concentrations.

No evidence of deformity or reproductive failure was observed for any bird or fish species. The study was not designed to assess reproduction or to determine the extent of embryonic deformities. 


\section{REFERENCES}

Barker, R.A., Dunlap, L.E., and Sauer, C.G., 1983, Analysis and computer simulation of stream-aquifer hydrology, Arkansas River valley, southwestern Kansas: U.S. Geological Survey Water-Supply Paper 2200, $59 \mathrm{p}$.

Beck, A.B., 1961, Observations on the copper metabolism of the domestic fowl and duck: Australian Journal of Agricultural Research, v. 12, no. 4, p. 743-753.

Cain, D.L., 1985, Quality of the Arkansas River and irrigation-return flows in the lower Arkansas River valley, Colorado: U.S. Geological Survey Water-Resources Investigations Report 84-4273, 85 p.

Cain, D.L., and Edelmann, P.R., 1980, Selected hydrologic data, Arkansas River basin, Pueblo and southeastern Fremont Counties, Colorado, 1975-80: U.S. Geological Survey Open-File Report 80-1185, 233 p.

Cain, D.L., Ryan, B.J., and Emmons, P.J., 1980, Hydrology and chemical quality of ground water in Crowley County, Colorado: U.S. Geological Survey Water-Resources Investigations Open-File Report 80-681, scale $1: 125,000,2$ sheets.

Camardese, M.B., Boffman, D.J., LeCaptain, L.J., and Pendleton, G.W., 1990, Effects of arsenate on growth and physiology in mallard ducklings: Environmental Toxicology and Chemistry, v. 9, no. 6, p. 785-795.

Colorado Department of Health, 1987, Classification and numeric standards for the Arkansas River basin--section 3.2.0: Colorado Department of Health Report 5 CCR 1002-8, unnumbered pages. 1988, The basic standards and methodologies for surface water-section 3.1.0: Colorado Department of Health Report 5 CCR 1002-8, unnumbered pages.

Cringan, M.S., 1989, Regional embient fish tissue monitoring program (RAFTMP) and Kansas follow-up studies program (KFSP) 1988 summary report: Bureau of Environmental Quality Division of Environment Kansas Department of Health and Environment, 25 p.

Dunlap, L.E., Lindgren, R.J., and Sauer, C.G., 1985, Geohydrology and model analysis of stream-aquifer system along the Arkansas River in Kearny and Finney Counties, southwestern Kansas: U.S. Geological Survey Water-Supply Paper 2253, 52 p.

Edwards, T.K., and Glysson, G.D., 1988, Field methods for measurement of fluvial sediment: U.S. Geological Survey Open-File Report 86-531, 118 p.

Eisler, R., 1987, Mercury hazards to fish, wildlife, and invertebrates-Synoptic review: U.S. Fish and Wildlife Service, Patuxent Wildlife Research Center Biological Report 85 (1.10), 90 p.

Farnsworth, R.K., and Thompson, E.S., 1982, Mean monthly, seasonal, and annual pan evaporation for the United States: National Oceanic and Atmospheric Administration Technical Report NWS 34, 85 p.

Finley, M.T., and Stendell, R.C., 1978, Survival and reproductive success of black ducks fed methyl mercury: Environmental Pollution, v. 16, no. 1, p. 51-64.

Fleming, W.J., Clark, D.R. Jr., and Henny, C.J., 1983, Organochlorine pesticides and PCB's--A continuing problem for the 1980's: Transactions of the 48th North American Wildlife and Natural Resources Conference, Wildlife Management Institute, p. 186-199.

Fishman, M.J., and Friedman, L.C., eds. 1985, Methods for determination of inorganic substances in water and fluvial sediments: U.S. Geological Survey Techniques of Water-Resources Investigations, bk. 5, chap. A1, 709 p. [Available as U.S. Geological Survey Open-File Report 85-495] 
Friedman, L.C., and Erdmann, D.E., 1982, Quality assurance practices for the chemical and biological analyses of water and fluvial sediments: U.S. Geological Survey, Techniques of Water Resources Investigations, bk. 5, chap. A6, $181 \mathrm{p}$.

Gillespie, R.B., and Baumann, P.C., 1986, Effects of high tissue concentrations of selenium on reproduction by bluegills: Transactions of the American Fisheries Society, v. 115, p. 208-213.

Gutentag, E.D., Lobmeyer, D.H., and Slagle, S.E., 1981, Geohydrology of southwestern Kansas: Kansas Geological Survey Irrigation Series 7, 73 p.

Guy, H.P., and Norman, V.W., 1970, Field methods for measurement of fluvial sediments: U.S. Geological Survey Techniques of Water-Resources Investigations, bk. 3 , chap. C2, $59 \mathrm{p}$.

Hatten, H.J., 1969, Selenium in the Upper Cretaceous Niobrara Formation and Pierre Shale of south-central Colorado [abs.], in Abstracts for 1968: Geological Society of America Special Paper 121, p. 606.

Heinz, G.H., 1980, Comparison of game-farm and wild-strain mallard ducks in accumulation of methyl mercury: Journal of Environmental Pathology and Toxicology, v. 3, no. $1 / 2$, p. 379-386.

Heinz, G.H., Hoffman, D.J., Krynitsky, A.J., and Weller, D.M.G., 1987, Reproduction in mallards fed selenium: Environmental Toxicology and Chemistry, v. 6, no. 6, p. 423-433.

Iorns, W.V., Hembree, C.H., and Oakland, G.L., 1965, Water resources of the Upper Colorado River Basin--Technical report: U.S. Geological Survey Professional Paper 441, 370 p.

Kansas Geological Survey, 1964, Geologic map of Kansas: Kansas Geological Survey map series $M-1$, scale $1: 500,000$, 1 sheet.

Kimball, B.A., and Wetherbee, G.A., 1989, Instream chemical reactions of acid mine water entering a neutral stream near Leadville, Colorado, in Mallard, G.E., and Ragone, S.E., eds., U.S. Geological Survey Toxic Substances Hydrology Program--Proceedings of the technical meeting, Phoenix, Arizona, September 26-30, 1988: U.S. Geological Survey Water-Resources Investigations Report 88-4220, p. 71-79.

Latta, B.F., 1944, Geology and ground-water resources of Finney and Gray Counties, Kansas: Kansas State Geological Survey Bulletin 55, 272 p.

Lemly, A.D., and Smith, G.J., 1987, Aquatic cycling of selenium--Implications for fish and wildlife: U.S. Fish and Wildlife Service, Fish and Wildlife Leaflet $12,10 \mathrm{p}$.

Lowe, T.P., May, T.W., Brumbaugh, W.G., and Kane, D.A., 1985, National contaminant biomonitoring program--Concentrations of seven elements in freshwater fish, 1978-1981: Archives of Environmental Contamination and Toxicology, v. 14, no. 3, p. 363-388.

Luckey, R.R., 1975, Hydrologic effects of reducing irrigation to maintain a permanent pool in John Martin Reservoir, Arkansas River valley, Colorado: U.S. Geological Survey Open-File Report 75-214, 13 p.

McBee, C.W., and others, 1961, Soil survey of Hamilton County, Kansas: U.S. Soil Conservation Service, 43 p.

Miles, D.L., 1977, Salinity in the Arkansas Valley of Colorado: U.S. Environmental Protection Agency Report EPA-1AG-D4-0544, 80 p.

Mustard, M.H., and Cain, D.L., 1981, Hydrology and chemical quality of ground water in Kiowa County, Colorado: U.S. Geological Survey Water-Resources Investigations Open-File Report 81-1023, 2 sheets. [Available from U.S. Geological Survey, Water Resources Division, room H-2103, Bldg. 53 (Box 25046, Mail Stop 415), Denver Federal Center, Denver, Co 80225] 
Ohlendorf, H.M., Hoffman, D.J., Saiki, M.K., and Aldrich, T.W., 1986, Embryonic mortality and abnormalities of aquatic birds--Apparent impacts of selenium from irrigation drainwater: The Science of the Total Environment, v. 52, no. 1/2, p. 49-63.

Ohlendorf, H.M., Risebrough, R.W., and Vermeer, Keith, 1978, Exposure of marine birds to environmental pollutants: U.S. Fish and Wildlife Service Wildlife Research Report 9, 40 p.

Oremland, R.S., Hollibaugh, J.T., Maest, A.S., Presser, T.S., Miller, L.G., and Culbertson, C.W., 1989, Selenate reduction to elemental selenium by anaerobic bacteria in sediments and culture--Biogeochemical significance of a novel, sulfate-independent respiration: Applied and Environmental Microbiology, v. 55, no. 9, p. 2333-2343.

Parker, H.N., 1911, Quality of the water supplies of Kansas, with a preliminary report on Stream pollution by mine waters in southeastern Kansas by E.H. Bailey: U.S. Geological Survey Water-Supply Paper 273, 375 p.

Rosenlund, B.D., 1986, Mercury in terrestrial and aquatic systems of the Turkey Creek drainage and Teller Reservoir, U.S. Army, Fort Carson, Colorado, 1985: U.S. Fish and Wildlife Service Colorado Fish and Wildlife Assistance Office, 730 Simms St., 非290, Golden, Colorado, 80401,16 p.

Schmitt, C.J., Zajicek, J.L., and Ribick, M.A., 1985, National pesticide monitoring program--Residues of organochlorine chemicals in freshwater fish, 1980-81: Archives of Environmental Contamination and Toxicology, v. 14 , no. 2 , p. 225-260.

Schultz, L.G., Tourtelot, H.A., Gill, J.R., and Boerngen, J.G., 1980, Composition and properties of the Pierre Shale and equivalent rocks, northern Great Plains region: U.S. Geological Survey Professional Paper 1064-B, $113 \mathrm{p}$.

Severson, R.C., Wilson, S.A., and McNeal, J.M., 1987, Analyses of bottom material collected at nine areas in the Western United States for the DOI irrigation drainage task group: U.S. Geological Survey Open-File Report $87-490,24 \mathrm{p}$.

Shacklette, H.T., and Boerngen, J.G., 1984, Element concentrations in soils and other surficial materials of the coterminous United States: U.S. Geological Survey Professional Paper 1270, 105 p.

Sparling, D.W., 1990, Acid precipitation and food quality--Inhibition of growth and survival in black ducks and mallards by dietary aluminum, calcium and phosphorus: Archives of Environmental Contamination and Toxicology, v. 19, no. 3, p. 457-463.

Spruill, T.B., 1983, Statistical summaries of selected chemical constituents in Kansas ground-water supplies: U.S. Geological Survey Open-File Report 83-263, 29 p.

Stephens, D.W., Wadde11, Bruce, and Miller, J.B., 1988, Reconnaissance investigation of water quality, bottom sediment, and biota associated with irrigation drainage in the middle Green River Basin, Utah, 1986-87: U.S. Geological Survey Water-Resources Investigations Report 88-4011, $70 \mathrm{p}$.

Taylor, 0.J., and Luckey, R.R., 1974, Water-management studies of a streamaquifer system, Arkansas River valley, Colorado: Ground Water, v. 12, no. 1, p. $22-38$.

Turekian, K.K., and Wedepoh1, K.H., 1961, Distribution of the elements in some major units of the earth's crust: Geological Society of America Bulletin, v. 72, no. 2, p. 175-191. 
Tweto, Ogden, 1979, Geologic map of Colorado: U.S. Geological Survey Map, scale $1: 500,000$.

U.S. Environmental Protection Agency, 1986, Quality criteria for water--1986: U.S. Environmental Protection Agency Report EPA-440/5-86-001 and updates, unnumbered pages. 1987, Ambient water quality criteria for selenium--1987: U.S. Environmental Protection Agency Report EPA-440/5-87-006, 39 p.

U.S. Fish and Wildlife Service, 1985, Procedures for resource contaminant assessment contract analytical work: U.S. Fish and Wildlife Service Habitat Resources Instructional Memorandum HRIM RCA 13.1, 203 p. 1990 , Summary report effects of irrigation drainwater contaminants on wildlife: U.S. Wildlife Service Patuxent Wildlife Research Center, Laurel, Maryland, 20708, 38 p.

U.S. Geological Survey, 1977, National handbook of recommended methods for water-data acquisition: Office of Water Data Coordination, various pagination. 1978-89, Water resources data for Kansas: U.S. Geological Survey Water-Data Reports (published annually). 1982-90, Water resources data for Colorado--Volume 1, Missouri River basin, Arkansas River basin, and Rio Grande basin: U.S. Geological Survey Water-Data Reports (published annually).

Wershaw, R.L., Fishman, M.J., Grabbe, R.R., and Lowe, L.E., eds., 1987, Methods for the determination of organic substances in water and fluvial sediments: U.S. Geological Survey Techniques of Water-Resources Investigations, bk. 5 , chap. A3, 80 p.

White, D.H., and Finley, M.T., 1978, Effects of dietary cadmium in mallard ducks, in Hemphill, D.H., ed., Trace substances in environmental health-XII--A symposium: Columbia, University of Missouri, p. 220-223. 
SUPPLEMENTAL DATA 
Table 8.--Water-quality data for samples from stream sites in the study area, August 1988

$\left[\mathrm{ft}^{3} / \mathrm{s}\right.$, cubic feet per second; $\mu \mathrm{S} / \mathrm{cm}$, microsiemens per centimeter at 25 degrees Celsius; ${ }^{\circ} \mathrm{C}$, degrees Celsius; $\mathrm{mg} / \mathrm{L}$, milligrams per liter; $\mu_{\mathrm{g}} / \mathrm{L}$, micrograms per liter; --, no data; <, less than]

\begin{tabular}{|c|c|c|c|c|c|c|c|c|c|c|}
\hline \multirow{2}{*}{$\begin{array}{l}\text { Property } \\
\text { or } \\
\text { constituent }\end{array}$} & \multirow[t]{2}{*}{ Units } & \multicolumn{9}{|c|}{$\begin{array}{l}\text { Site number } \\
\text { (fig. } 7 \text { ) }\end{array}$} \\
\hline & & $\overline{A 1}$ & T1 & $\mathrm{T} 2$ & $\overline{A 2}$ & A3 & A4 & A5 & A6 & A7 \\
\hline $\begin{array}{l}\text { Sampling date } \\
\text { Sampling time }\end{array}$ & $\begin{array}{l}\text { none } \\
\text { hours }\end{array}$ & $\begin{array}{l}8-15-88 \\
1230\end{array}$ & $\begin{array}{l}8-16-88 \\
0800\end{array}$ & $\begin{array}{l}8-16-88 \\
1030\end{array}$ & $\begin{array}{l}8-16-88 \\
1500\end{array}$ & $\begin{array}{l}8-17-88 \\
0830\end{array}$ & $\begin{array}{l}8-17-88 \\
1040\end{array}$ & $\begin{array}{l}8-18-88 \\
0815\end{array}$ & $\begin{array}{l}8-17-88 \\
1020\end{array}$ & $\begin{array}{l}8-18-88 \\
0925\end{array}$ \\
\hline \multicolumn{11}{|c|}{ PROPERTIES } \\
\hline $\begin{array}{l}\text { Streamflow } \\
\text { Specific } \\
\text { conductance }\end{array}$ & $\begin{array}{l}\mathrm{ft}^{3} / \mathrm{s} \\
\mu S / \mathrm{cm}\end{array}$ & $\begin{array}{l}775 \\
461\end{array}$ & $\begin{array}{r}68 \\
1,440\end{array}$ & $2,450^{9.6}$ & $\begin{array}{l}678 \\
695\end{array}$ & $\begin{array}{r}53.2 \\
2,130\end{array}$ & $\begin{array}{l}1,090 \\
2,220\end{array}$ & $\begin{array}{r}512 \\
--\end{array}$ & $\begin{array}{r}557 \\
2,670\end{array}$ & $\begin{array}{r}63 \\
2,940\end{array}$ \\
\hline pH & standard & 8.3 & 8.4 & 8.2 & 8.4 & 8.3 & 8.5 & 8.4 & 8.2 & 8.2 \\
\hline Temperature & ${ }^{\circ} \mathrm{C}$ & 21 & 17 & 21 & 26 & 19 & 25 & 22 & 22 & 22.5 \\
\hline Dissolved oxygen & $\mathrm{mg} / \mathrm{L}$ & 8.6 & 7.5 & 11.2 & 7.5 & 8.2 & 8.4 & 8.4 & 7.6 & 8.1 \\
\hline Hardness as $\mathrm{CaCO}_{3}$ & $\mathrm{mg} / \mathrm{L}$ & 190 & 450 & 1,300 & 270 & 950 & 860 & 890 & 1,070 & 1,080 \\
\hline Alkalinity as $\mathrm{CaCO}_{3}$ & $\mathrm{mg}_{\mathrm{g}} / \mathrm{L}$ & 110 & 200 & 190 & 130 & 220 & 140 & 150 & 180 & 150 \\
\hline \multicolumn{11}{|c|}{ CONSTITUENTS } \\
\hline Dissolved solids & $\mathrm{mg}_{\mathrm{g}} / \mathrm{L}$ & 290 & 980 & 2,070 & 456 & 1,740 & 1,680 & 1,870 & 2,450 & 2,600 \\
\hline Calcium & $\mathrm{mg}_{\mathrm{g}} / \mathrm{L}$ & 52 & 110 & 340 & 71 & 240 & 180 & 190 & 230 & 219 \\
\hline Magnesium & $\mathrm{mg} / \mathrm{L}$ & 15 & 42 & 110 & 22 & 84 & 100 & 100 & 120 & 130 \\
\hline Sodium & $\mathrm{mg} / \mathrm{L}$ & 21 & 140 & 96 & 37 & 170 & 210 & 230 & 280 & 330 \\
\hline Potassium & $\mathrm{mg} / \mathrm{L}$ & 3 & 7 & 6 & 3 & 5 & 7 & 6 & 9 & 10 \\
\hline Chloride & $\mathrm{mg} / \mathrm{L}$ & 7.1 & 49 & 19 & 12 & 45 & 60 & 64 & 88 & 98 \\
\hline Sulfate & $\mathrm{mg} / \mathrm{L}$ & 110 & 460 & 1,200 & 210 & 940 & 1,000 & 1,100 & 1,400 & 1,600 \\
\hline $\begin{array}{l}\text { Nitrite plus nitrate } \\
\text { as nitrogen }\end{array}$ & $\mathrm{mg} / \mathrm{L}$ & 0.26 & 4.7 & 1.7 & 0.95 & 3.5 & $<0.10$ & 0.21 & 0.88 & 0.66 \\
\hline Arsenic & $\mu_{\mathbf{g}} / \mathrm{L}$ & 1 & 4 & 1 & 2 & 1 & 1 & 1 & 2 & $<1$ \\
\hline Boron & $\mu_{g} / L$ & 30 & 220 & 190 & 60 & 280 & 280 & 310 & 430 & 470 \\
\hline Cadmium & $\mu_{8} / L$ & $<1$ & $<1$ & $<1$ & 2 & $<1$ & 1 & $<1$ & $<1$ & $<1$ \\
\hline Chromium & $\mu_{g} / L$ & $<1$ & 1 & 2 & 1 & 2 & $<1$ & 2 & 1 & 1 \\
\hline Copper & $\mu_{g} / L$ & 2 & 3 & 4 & 6 & 3 & 3 & 2 & 2 & 2 \\
\hline Lead & $\mu_{g} / L$ & $<5$ & $<5$ & $<5$ & $<5$ & $<5$ & $<5$ & $<\overline{5}$ & $<5$ & $<5$ \\
\hline Mercury & $\mu_{g} / L$ & 0.9 & 0.5 & 0.2 & 0.2 & 0.2 & 0.2 & 0.3 & 0.1 & $<0.1$ \\
\hline Molybdenum & $\mu g / L$ & 5 & 8 & 8 & 6 & 5 & 7 & 7 & 6 & 6 \\
\hline Selenium & $\mu_{g} / L$ & 2 & 45 & 52 & 8 & 17 & 5 & 5 & 9 & 10 \\
\hline Uranium & $\mu g / L$ & 5.1 & 9.4 & 25 & 7.6 & 24 & 22 & 23 & 33 & 33 \\
\hline Vanadium & $\mu_{g} / L$ & 1 & 3 & $<1$ & 2 & 2 & 1 & $<1$ & 2 & 3 \\
\hline Zinc & $\mu_{g} / L$ & 7 & 11 & $<10$ & 5 & 10 & 20 & 10 & 5 & 3 \\
\hline
\end{tabular}


Table 9.--Water-quality data for samples from reservoir sites in the study area, June 1988

[m, meters; $\mu \mathrm{S} / \mathrm{cm}$, microsiemens per centimeter at 25 degrees Celsius; ${ }^{\circ} \mathrm{C}$, degree Celsius; mg/L, milligrams per liter; $\mu g / L$, micrograms per liter; --, no data; <, less than]

\begin{tabular}{|c|c|c|c|c|c|c|}
\hline \multirow{2}{*}{$\begin{array}{l}\text { Property } \\
\text { or } \\
\text { constituent }\end{array}$} & \multirow[t]{2}{*}{ Units } & \multicolumn{5}{|c|}{$\begin{array}{l}\text { Site number } \\
\text { (fig. } 7)\end{array}$} \\
\hline & & R1 & R2 & R3 & R4 & R5 \\
\hline $\begin{array}{l}\text { Sampling date } \\
\text { Sampling time } \\
\text { Sampling depth } \\
\text { Bottom depth }\end{array}$ & $\begin{array}{l}\text { none } \\
\text { hours } \\
\mathrm{m} \\
\mathrm{m}\end{array}$ & $\begin{array}{c}6-14-88 \\
0850 \\
0.5 \\
9.0\end{array}$ & $\begin{array}{c}6-14-88 \\
1450 \\
0.5 \\
3.0\end{array}$ & $\begin{array}{c}6-16-88 \\
0850 \\
0.5 \\
7.5\end{array}$ & $\begin{array}{c}6-16-88 \\
1115 \\
0.5 \\
9.6\end{array}$ & $\begin{array}{c}6-15-88 \\
1315 \\
0.5 \\
1.7\end{array}$ \\
\hline \multicolumn{7}{|c|}{ PROPERTIES } \\
\hline $\begin{array}{l}\text { Specific conductance } \\
\text { pH } \\
\text { Temperature } \\
\text { Transparency } \\
\text { Dissolved oxygen } \\
\text { Hardness as } \mathrm{CaCO}_{3} \\
\text { Alkalinity as } \mathrm{CaCO}_{3}\end{array}$ & $\begin{array}{l}\mu \mathrm{S} / \mathrm{cm} \\
\mathrm{standard} \\
{ }^{\circ} \mathrm{C} \\
\mathrm{m} \\
\mathrm{mg} / \mathrm{L} \\
\mathrm{mg} / \mathrm{L} \\
\mathrm{mg} / \mathrm{L}\end{array}$ & $\begin{array}{c}259 \\
7.9 \\
19.0 \\
0.6 \\
6.9 \\
110 \\
68\end{array}$ & $\begin{array}{r}2,600 \\
8.1 \\
22.1 \\
0.4 \\
7.9 \\
860 \\
120\end{array}$ & $\begin{array}{c}1,680 \\
8.2 \\
21.1 \\
1.0 \\
7.5 \\
610 \\
140\end{array}$ & $\begin{array}{c}2,070 \\
8.2 \\
21.5 \\
1.5 \\
8.1 \\
740 \\
150\end{array}$ & $\begin{array}{c}3,825 \\
8.2 \\
22.8 \\
0.3 \\
-- \\
1,400 \\
110\end{array}$ \\
\hline \multicolumn{7}{|c|}{ CONSTITUENTS } \\
\hline $\begin{array}{l}\text { Dissolved solids } \\
\text { Calcium } \\
\text { Magnesium } \\
\text { Sodium } \\
\text { Potassium }\end{array}$ & $\begin{array}{l}\mathrm{mg} / \mathrm{L} \\
\mathrm{mg} / \mathrm{L} \\
\mathrm{mg} / \mathrm{L} \\
\mathrm{mg} / \mathrm{L} \\
\mathrm{mg} / \mathrm{L}\end{array}$ & $\begin{array}{c}156 \\
31 \\
7.8 \\
9.7 \\
2\end{array}$ & $\begin{array}{r}2,060 \\
180 \\
99 \\
280 \\
9\end{array}$ & $\begin{array}{r}1,300 \\
130 \\
70 \\
140 \\
10\end{array}$ & $\begin{array}{r}1,680 \\
160 \\
82 \\
190 \\
6\end{array}$ & $\begin{array}{r}3,240 \\
260 \\
180 \\
450 \\
12\end{array}$ \\
\hline $\begin{array}{l}\text { Chloride } \\
\text { Sulfate }\end{array}$ & $\begin{array}{l}\mathrm{mg} / \mathrm{L} \\
\mathrm{mg} / \mathrm{L}\end{array}$ & 51 & $\begin{array}{r}100 \\
1,200\end{array}$ & $\begin{array}{r}48 \\
740\end{array}$ & $\begin{array}{r}56 \\
960\end{array}$ & $\begin{array}{r}130 \\
2,000\end{array}$ \\
\hline $\begin{array}{l}\text { Nitrite plus nitrate } \\
\text { as nitrogen }\end{array}$ & $\mathrm{mg} / \mathrm{L}$ & 0.18 & $<0.10$ & $<0.10$ & $<0.10$ & $<0.10$ \\
\hline $\begin{array}{l}\text { Arsenic } \\
\text { Boron }\end{array}$ & $\begin{array}{l}\mu_{g} / L \\
\mu_{g} / L\end{array}$ & $\begin{array}{r}1 \\
20\end{array}$ & $\begin{array}{r}2 \\
600\end{array}$ & $\begin{array}{r}2 \\
260\end{array}$ & $\begin{array}{r}1 \\
280\end{array}$ & $\begin{array}{r}1 \\
640\end{array}$ \\
\hline $\begin{array}{l}\text { Cadmium } \\
\text { Chromium } \\
\text { Copper } \\
\text { Lead } \\
\text { Mercury }\end{array}$ & $\begin{array}{l}\mu \mathrm{g} / \mathrm{L} \\
\mu \mathrm{g} / \mathrm{L} \\
\mu \mathrm{g} / \mathrm{L} \\
\mu \mathrm{g} / \mathrm{L} \\
\mu \mathrm{g} / \mathrm{L}\end{array}$ & $\begin{array}{l}<1 \\
<1 \\
3 \\
<5 \\
0.6\end{array}$ & $\begin{array}{c}1 \\
<1 \\
4 \\
<5 \\
0.6\end{array}$ & $\begin{array}{l}<1 \\
<1 \\
3 \\
<5 \\
0.1\end{array}$ & $\begin{array}{l}1 \\
<1 \\
2 \\
<5 \\
<0.1\end{array}$ & $\begin{array}{l}2 \\
1 \\
2 \\
<5 \\
0.1\end{array}$ \\
\hline $\begin{array}{l}\text { Molybdenum } \\
\text { Selenium } \\
\text { Uranium } \\
\text { Vanadium } \\
\text { Zinc }\end{array}$ & $\begin{array}{l}\mu_{g} / L \\
\mu_{g} / L \\
\mu_{g} / L \\
\mu_{g} / L \\
\mu_{g} / L\end{array}$ & $\begin{array}{l}3 \\
1 \\
3.0 \\
2 \\
3\end{array}$ & $\begin{array}{r}19 \\
7 \\
18 \\
3 \\
10\end{array}$ & $\begin{array}{r}16 \\
4 \\
17 \\
2 \\
4\end{array}$ & $\begin{array}{r}7 \\
6 \\
19 \\
<1 \\
<10\end{array}$ & $\begin{array}{r}9 \\
9 \\
47 \\
2 \\
20\end{array}$ \\
\hline
\end{tabular}


Table 10.--Water-quality data for samples from reservoir sites in the study area, October 1988

[m, meters; $\mu \mathrm{S} / \mathrm{cm}$, microsiemans per centimeter at 25 degrees Celsius; ${ }^{\circ} \mathrm{C}$, degree Celsius; mg/L, milligrams per liter; $\mu_{g} / L$, micrograms per liter; --, no data; <, less than]

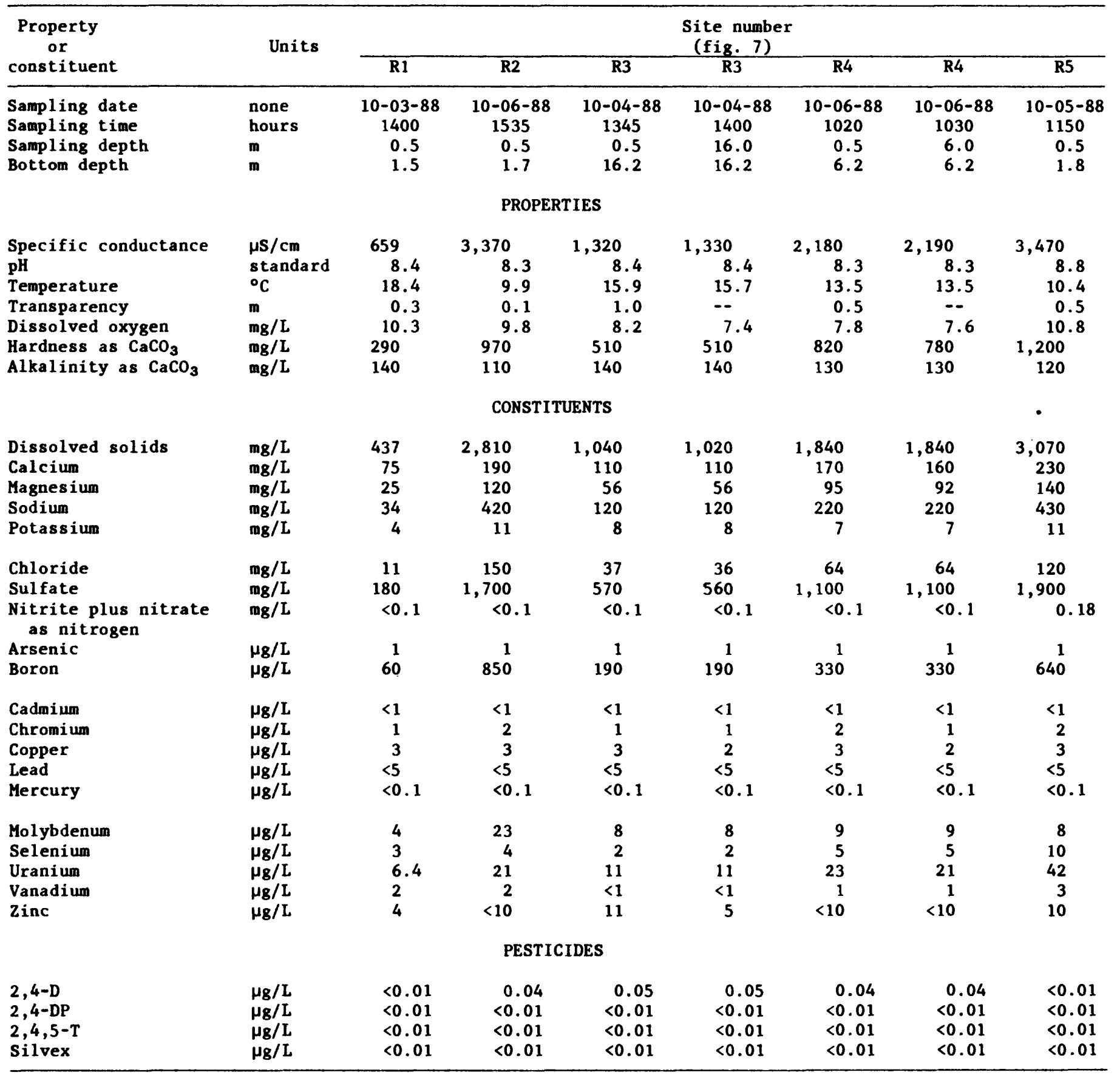


Table 11.--Water-quality data for samples from ground-water sites in the study area, August 1988

$\left[\mu \mathrm{S} / \mathrm{cm}\right.$, microsiemens per centimeter at 25 degrees Celsius; ${ }^{\circ} \mathrm{C}$, degree Celsius; mg/L, milligram per liter; $\mu g / L$, microgram per liter; <, less than]

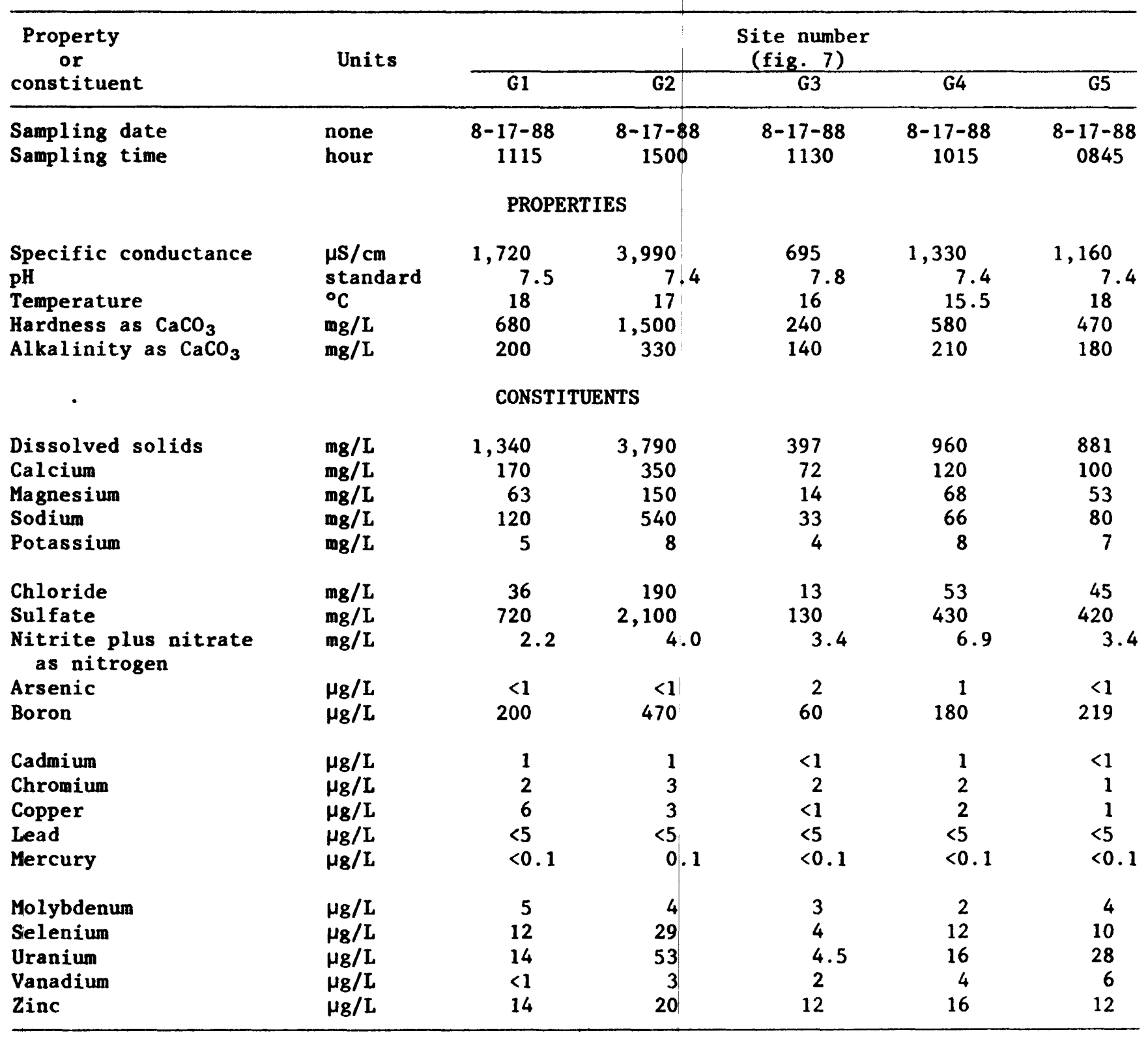


Table 12.--Chemical data for bottom-sediment samples from stream sites in the study area, August 1988 $[\mu \mathrm{g} / \mathrm{g}$, micrograms per gram; <, less than; --, no data]

\begin{tabular}{|c|c|c|c|c|c|c|c|c|c|}
\hline \multirow[t]{2}{*}{ Constituent } & \multirow[t]{2}{*}{ Units } & \multicolumn{8}{|c|}{$\begin{array}{c}\text { Site number } \\
\text { (fig. } 7 \text { ) }\end{array}$} \\
\hline & & T1 & $\mathrm{T2}$ & A2 & A3 & A4 & A5 & A6 & A7 \\
\hline \multirow[t]{2}{*}{$\begin{array}{l}\text { Sampling date } \\
\text { Sampling time }\end{array}$} & $\begin{array}{l}\text { none } \\
\text { hours }\end{array}$ & $\begin{array}{c}8-16-88 \\
0820\end{array}$ & $\begin{array}{c}8-16-88 \\
1045\end{array}$ & $\begin{array}{c}8-16-88 \\
1545\end{array}$ & $\begin{array}{c}8-17-88 \\
0755\end{array}$ & $\begin{array}{c}8-18-88 \\
1130\end{array}$ & $\begin{array}{c}8-18-88 \\
0845\end{array}$ & $\begin{array}{c}8-17-88 \\
1020\end{array}$ & $\begin{array}{c}8-18-88 \\
0925\end{array}$ \\
\hline & \multicolumn{8}{|c|}{ PARTICLE SIZE <0.062 MILLIMETER } & \\
\hline $\begin{array}{l}\text { Arsenic } \\
\text { Cadmium } \\
\text { Chromium } \\
\text { Copper } \\
\text { Lead }\end{array}$ & $\begin{array}{l}\mu g / g \\
\mu_{g} / g \\
\mu g / g \\
\mu_{g} / g \\
\mu_{g} / g\end{array}$ & $\begin{array}{l}4.8 \\
<2 \\
37 \\
14 \\
28\end{array}$ & $\begin{array}{l}6.9 \\
<2 \\
59 \\
21 \\
17\end{array}$ & $\begin{array}{l}3.0 \\
<2 \\
28 \\
7 \\
29\end{array}$ & $\begin{array}{l}4.6 \\
<2 \\
38 \\
9 \\
27\end{array}$ & $\begin{array}{l}6.2 \\
<2 \\
81 \\
22 \\
23\end{array}$ & $\begin{array}{l}4.4 \\
<2 \\
58 \\
12 \\
20\end{array}$ & $\begin{array}{l}2.8 \\
<2 \\
28 \\
8 \\
20\end{array}$ & $\begin{array}{c}3.0 \\
<2 \\
99 \\
540 \\
29\end{array}$ \\
\hline $\begin{array}{l}\text { Mercury } \\
\text { Molybdenum } \\
\text { Nickel } \\
\text { Selenium } \\
\text { Uranium }\end{array}$ & $\begin{array}{l}\mu g / g \\
\mu_{g} / g \\
\mu_{g} / g \\
\mu_{g} / g \\
\mu_{g} / g\end{array}$ & $\begin{array}{l}0.06 \\
<2 \\
18 \\
0.5 \\
1.3\end{array}$ & $\begin{array}{c}<0.02 \\
4 \\
24 \\
2.1 \\
2.3\end{array}$ & $\begin{array}{l}<0.02 \\
<2 \\
12 \\
0.5 \\
0.9\end{array}$ & $\begin{array}{l}<0.02 \\
<2 \\
22 \\
0.7 \\
0.7\end{array}$ & $\begin{array}{l}0.02 \\
<2 \\
24 \\
1.3 \\
1.8\end{array}$ & $\begin{array}{l}<0.02 \\
<2 \\
22 \\
1.0 \\
1.5\end{array}$ & $\begin{array}{l}0.04 \\
<2 \\
14 \\
0.6 \\
1.2\end{array}$ & $\begin{array}{l}0.54 \\
<2 \\
46 \\
0.6 \\
0.7\end{array}$ \\
\hline $\begin{array}{l}\text { Vanadium } \\
\text { Zinc } \\
\text { Organic carbon }\end{array}$ & $\begin{array}{l}\mu_{g} / g \\
\mu_{g} / g \\
\text { percent }\end{array}$ & $\begin{array}{l}20 \\
44 \\
--\end{array}$ & $\begin{array}{l}91 \\
72 \\
0.69\end{array}$ & $\begin{array}{l}32 \\
55 \\
0.41\end{array}$ & $\begin{array}{l}45 \\
81 \\
--\end{array}$ & $\begin{array}{l}77 \\
76 \\
1.20\end{array}$ & $\begin{array}{l}80 \\
62 \\
0.56\end{array}$ & $\begin{array}{l}27 \\
29 \\
0.48\end{array}$ & $\begin{array}{l}25 \\
210 \\
0.63\end{array}$ \\
\hline \multicolumn{10}{|c|}{ PARTICLE SIZE <2.0 MILLIMETERS } \\
\hline $\begin{array}{l}\text { Arsenic } \\
\text { Boron } \\
\text { Cadmium } \\
\text { Chromium } \\
\text { Copper }\end{array}$ & $\begin{array}{l}\mu g / g \\
\mu g / g \\
\mu g / g \\
\mu g / g \\
\mu g / g\end{array}$ & $\begin{array}{r}2 \\
0.4 \\
<2 \\
3 \\
3\end{array}$ & $\begin{array}{l}2.7 \\
0.6 \\
<2 \\
19 \\
6\end{array}$ & $\begin{array}{l}1 \\
0.4 \\
<2 \\
8 \\
4\end{array}$ & $\begin{array}{l}1 \\
0.4 \\
<2 \\
7 \\
4\end{array}$ & $\begin{array}{l}2.4 \\
0.7 \\
<2 \\
16 \\
5\end{array}$ & $\begin{array}{l}2.3 \\
0.5 \\
<2 \\
11 \\
3\end{array}$ & $\begin{array}{l}1 \\
0.5 \\
<2 \\
4 \\
3\end{array}$ & $\begin{array}{l}1 \\
0.5 \\
<2 \\
5 \\
7\end{array}$ \\
\hline $\begin{array}{l}\text { Lead } \\
\text { Mercury } \\
\text { Molybdenum } \\
\text { Nickel } \\
\text { Selenium }\end{array}$ & $\begin{array}{l}\mu_{g} / g \\
\mu_{g} / g \\
\mu_{g} / g \\
\mu_{g} / g \\
\mu_{g} / g\end{array}$ & $\begin{array}{l}18 \\
<0.02 \\
<2 \\
<2 \\
\quad 0.2\end{array}$ & $\begin{array}{l}19 \\
<0.02 \\
<2 \\
8 \\
0.8\end{array}$ & $\begin{array}{l}19 \\
<0.02 \\
<2 \\
3 \\
0.2\end{array}$ & $\begin{array}{l}19 \\
<0.02 \\
<2 \\
3 \\
0.2\end{array}$ & $\begin{array}{l}15 \\
<0.02 \\
<2 \\
8 \\
0.3\end{array}$ & $\begin{array}{l}17 \\
<0.02 \\
<2 \\
4 \\
0.2\end{array}$ & $\begin{array}{l}16 \\
<0.02 \\
<2 \\
2 \\
0.1\end{array}$ & $\begin{array}{l}16 \\
<0.02 \\
<2 \\
3 \\
0.1\end{array}$ \\
\hline $\begin{array}{l}\text { Uranium } \\
\text { Vanadium } \\
\text { Zinc } \\
\text { Organic carbon }\end{array}$ & $\begin{array}{l}\mu_{g} / g \\
\mu_{g} / g \\
\mu_{g} / g \\
\text { percent }\end{array}$ & $\begin{array}{l}0.50 \\
5 \\
11 \\
0.08\end{array}$ & $\begin{array}{l}0.80 \\
63 \\
26 \\
0.14\end{array}$ & $\begin{array}{l}0.50 \\
13 \\
26 \\
0.07\end{array}$ & $\begin{array}{l}0.45 \\
13 \\
23 \\
0.09\end{array}$ & $\begin{array}{l}0.55 \\
23 \\
23 \\
0.23\end{array}$ & $\begin{array}{l}0.60 \\
24 \\
17 \\
0.08\end{array}$ & $\begin{array}{l}0.60 \\
7 \\
10 \\
0.08\end{array}$ & $\begin{array}{l}0.55 \\
7 \\
15 \\
0.67\end{array}$ \\
\hline
\end{tabular}


Table 13.--Chemical data for bottom-sediment samples collected at reservoir sites in the study area, October 1988

[ $\mu_{g} / g$, micrograms per gram; $\mu_{g} / \mathbf{k g}$, microgram per kilogram;<, less than; --, no data]

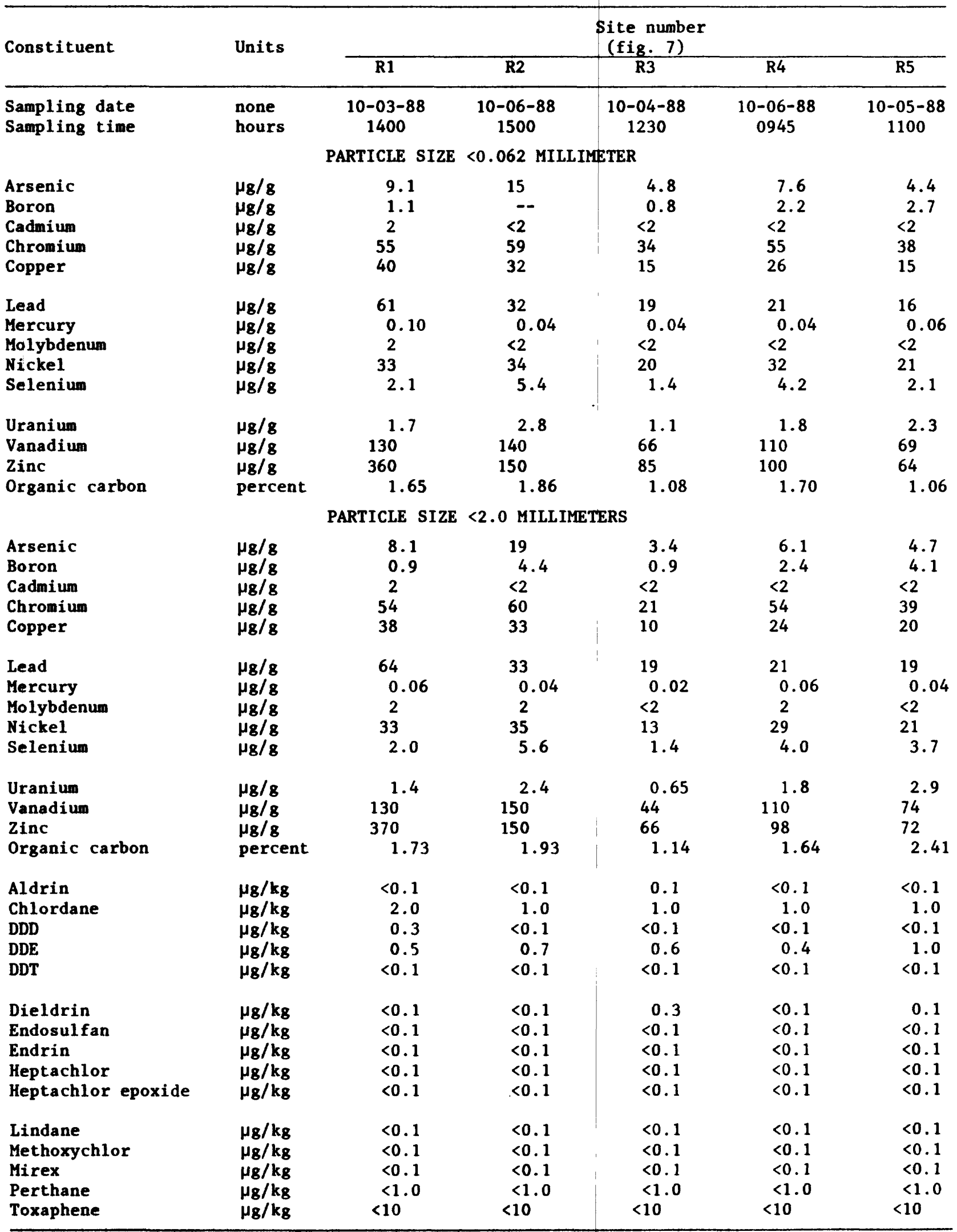


Table 14.--Trace-element concentrations in acult livers from individuals or composite samples of waterbirds collected at reservoir sites in the study area, June 7-10, 1988

[Sampling sites are shown in figure 7; killdeer samples are a composite from three or fewer individuals and all other samples are from individual birds; $F$, female, $M$, male, $X$, mix of females and males; 〈, less than; --, geometric mean not calculated]

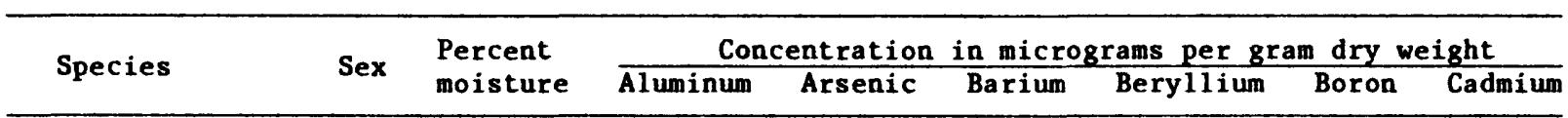

PUEBLO RESERVOIR (Site R1)

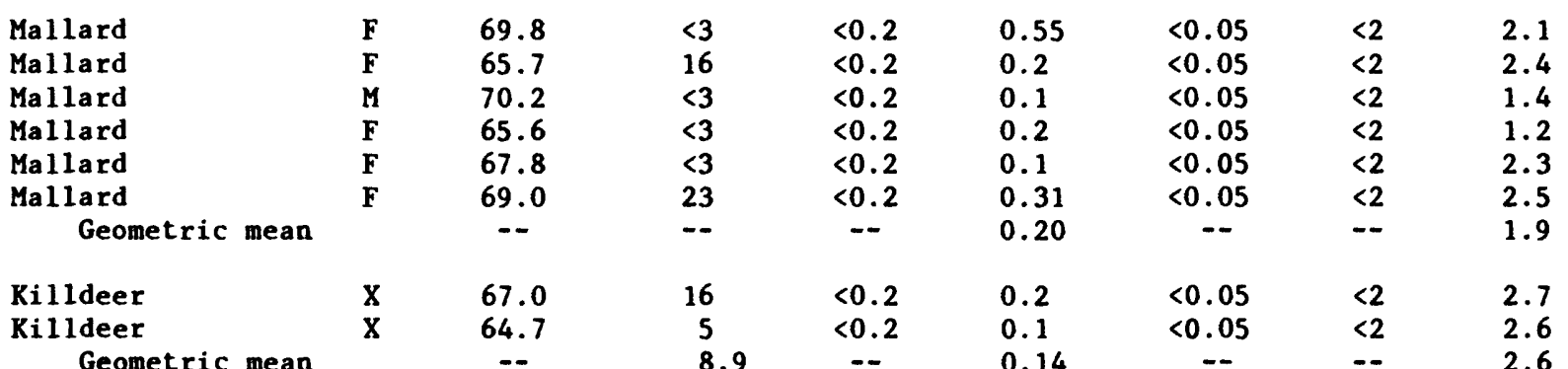

Geometric mean

LAKE MEREDITH (Site R2)

Mallard
Mallard
Mallard
Mallard
Mallard
Mallard
Geometric mean

American coot

American coot

American coot

American coot

American coot

American coot

Geometric mean

$\begin{array}{cc}\text { F } & 83.0 \\ \text { F } & 72.7 \\ \text { F } & 71.0 \\ \text { F } & 72.3 \\ \text { F } & 69.3 \\ \text { F } & 70.6 \\ & --\end{array}$

$\begin{aligned} 4 & <0.2 \\ 5 & <0.2 \\ 10 & <0.2 \\ 5 & <0.2 \\ 3 & <0.2 \\ 11 & <0.2\end{aligned}$

0.1

0.2

$<0.05$

$<0.05$

0.2

0.32

$<0.05$

0.1

$<0.05$

$<0.05$

1.0

$<0.05$

2.6

Killdeer

Killdeer

Geometric mean

M $\quad 71.4$

5.7

--

0.2

--

3.7

$<0.2$

1.5

1.1

1.0

1.8

1.0

Black-necked stilt

$\begin{array}{ll}M & 74.3 \\ F & 73.2\end{array}$

$$
17
$$

$<0.2$

$<0.1$

$<0.05$

$<3$

$<0.2$

$<0.1$

$<0.05$

$<0.05$

70.9

$<0.2$

$<0.1$

$<0.05$

$<0.05$

$<0.2$

$<0,1$

74.8
75.0

3
6

$<0.2$

$<0.1$

$<0.1$

$-$

$<0.1$

1

$<0.3$

0.7

$<0.4$

$<0.3$

--

4.6

$-$

0.29

$<0.2$

0.2

$<0.05$

$<0.05$

0.2

0.3

\begin{tabular}{l}
$X$ \\
$X \quad 67.6$ \\
\hline
\end{tabular}

14

$<0.2$

0.24

--

1.2

5

13

$<0.2$

0.1

$<0.05$

1.5

GREAT PLAINS RESERVOIRS (Site R3)

Mallard
Killdeer
Killdeer
Geometric mean

$\mathbf{F}$
$\mathbf{X}$
$\mathbf{X}$

$<3$
34
7
15

$<0.2$
$<0.2$
$<0.2$

0.1

$<0.05$

$<2$

1.6

68.2
67.4
.-

--

0.3

0.1

$<0.05$

$<0.05$

$<2$
$<2$

1.4

0.2

$--$

$--$

1.3

JOHN MARTIN RESERVOIR (Site R4)

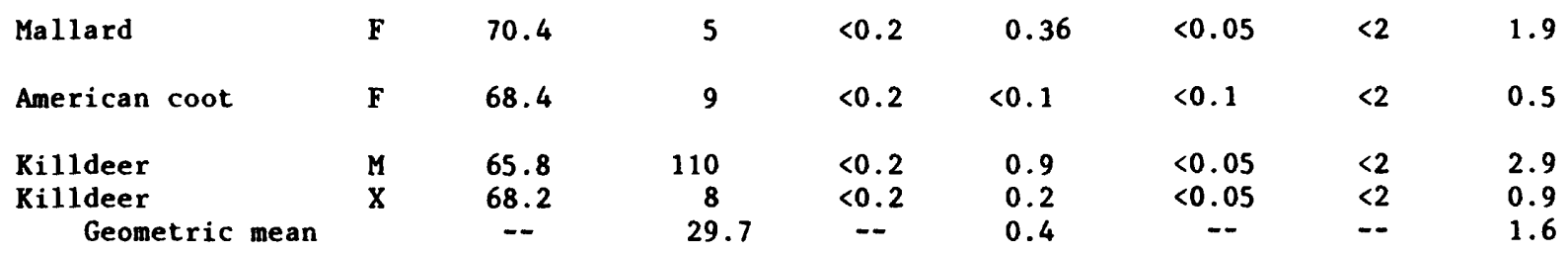


Table 14.--Trace-element concentrations in adult livers from individuals or composite samples of waterbirds collected at reservoir sites in the study area, June 7-10, 1988--Continued

\begin{tabular}{|c|c|c|c|c|c|c|c|c|}
\hline \multirow{2}{*}{ Species } & \multirow{2}{*}{ Sex } & \multirow{2}{*}{$\begin{array}{l}\text { Percent } \\
\text { moisture }\end{array}$} & \multicolumn{6}{|c|}{ Concentration in micrograms per gram dry weight } \\
\hline & & & Aluminum & Arsenic & Barium & Beryllium & Boron & Cadmium \\
\hline \multicolumn{9}{|c|}{ LAKE MCKINNEY (Site R5) } \\
\hline Mallard & $\mathbf{F}$ & 70.7 & $<3$ & $<0.2$ & 0.2 & $<0.05$ & $<2$ & 0.8 \\
\hline Mallard & $\mathbf{F}$ & 70.5 & 7 & $<0.2$ & 0.1 & $<0.05$ & $<2$ & 3.6 \\
\hline Mallard & $\mathbf{F}$ & 70.4 & $<3$ & $<0.2$ & $<0.1$ & $<0.05$ & $<2$ & 3.6 \\
\hline Geometric mean & & -- & -- & -- & 0.1 & - & -- & 2.2 \\
\hline American coot & $\mathbf{F}$ & 72.2 & $<3$ & $<0.2$ & $<0.1$ & $<0.1$ & 3 & $<0.2$ \\
\hline American coot & $\mathbf{M}$ & 70.3 & 8 & $<0.2$ & $<0.1$ & $<0.1$ & $<2$ & 2.5 \\
\hline Geometric mean & & -- & 3.5 & -- & -- & -- & 2.1 & 0.5 \\
\hline Killdeer & $\mathrm{x}$ & 67.5 & 7 & $<0.2$ & 0.1 & $<0.05$ & $<2$ & 2.3 \\
\hline Killdeer & $\mathbf{X}$ & 67.9 & $<3$ & $<0.2$ & 0.1 & $<0.05$ & $<2$ & 2.6 \\
\hline Geometric mean & & -- & 3.2 & -- & 0.1 & -- & -- & 2.4 \\
\hline Northern shoveler & $\mathbf{F}$ & 66.5 & $<3$ & $<0.2$ & $<0.1$ & $<0.1$ & $<2$ & 0.4 \\
\hline Blue-winged teal & $\mathbf{M}$ & 72.2 & 6 & $<0.2$ & 0.1 & $<0.1$ & $<2$ & 2.3 \\
\hline Blue-winged teal & $\mathbf{M}$ & 67.8 & $<3$ & $<0.2$ & 0.1 & $<0.1$ & $<2$ & 1.9 \\
\hline Blue-winged teal & $\mathbf{M}$ & 69.1 & 7 & $<0.2$ & 0.2 & $<0.1$ & $<2$ & 0.74 \\
\hline Geometric mean & & -- & 4.0 & -- & 0.1 & -- & -- & 1.5 \\
\hline
\end{tabular}

Species Concentration in micrograms per gram dry weight

Chromium Copper Iron Lead Magnesium Manganese Mercury Molybdenum

PUEBLO RESERVOIR (Site R1)

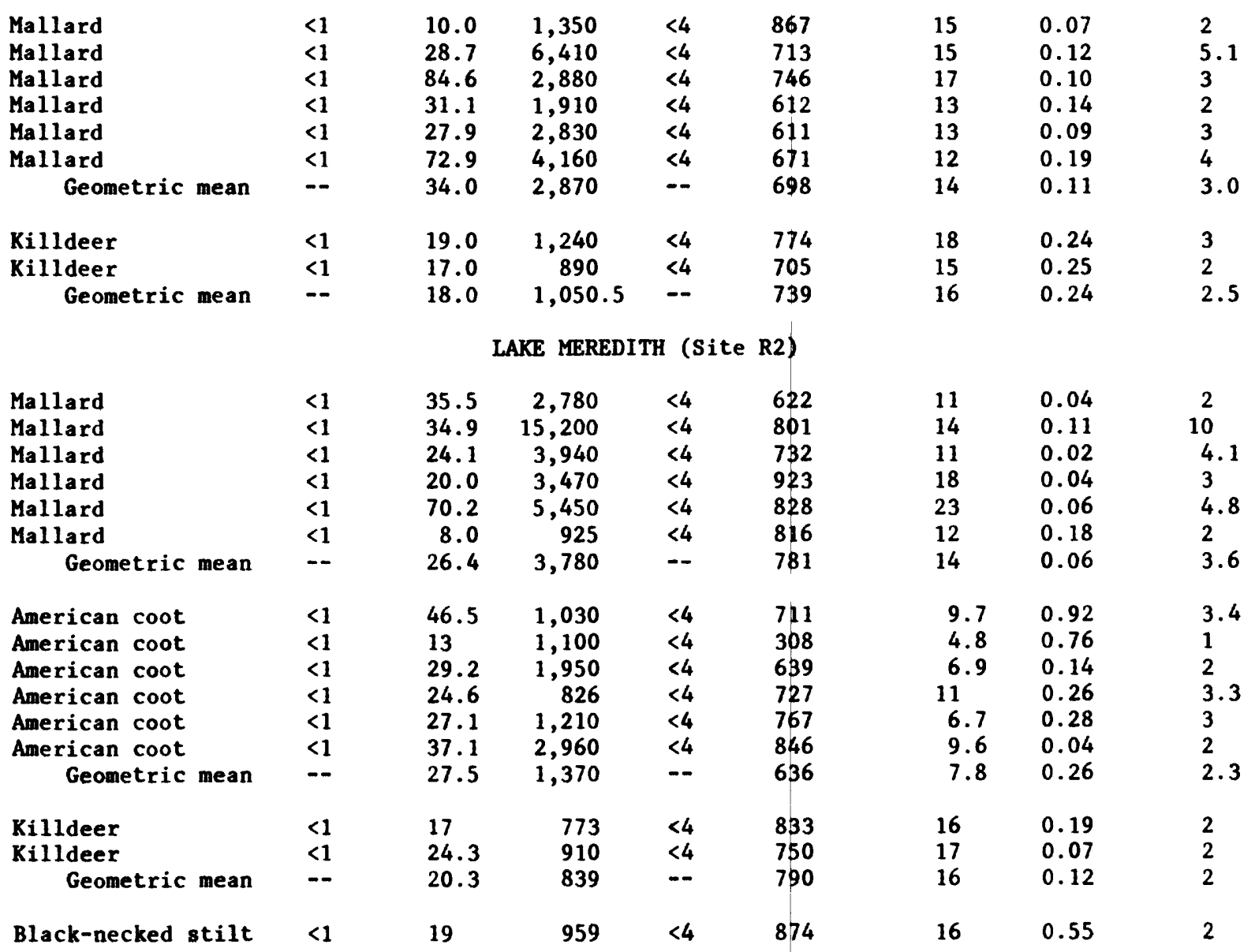


Table 14.--Trace-element concentrations in adult livers from individuals or composite samples of waterbirds collected at reservoir sites in the study area, June 7-10, 1988--Continued

\begin{tabular}{|c|c|c|c|c|c|c|c|c|}
\hline \multirow[b]{2}{*}{ Species } & \multicolumn{8}{|c|}{ Concentration in micrograms per gram dry weight } \\
\hline & Chromium & Copper & Iron & Lead & Magnesium & Manganese & Mercury & Molybdenum \\
\hline \multicolumn{9}{|c|}{ GREAT PLAINS RESERVOIRS (Site R3) } \\
\hline Mallard & $<1$ & 35.5 & 5,050 & $<4$ & 648 & 12 & 0.19 & 3 \\
\hline Killdeer & $<1$ & 14 & 809 & $<4$ & 778 & 14 & 0.10 & 2 \\
\hline Killdeer & $<1$ & 18 & 1,150 & $<4$ & 769 & 16 & 0.12 & 3 \\
\hline Geometric mean & -- & 16 & 964 & -- & 773 & 15 & 0.11 & 2 \\
\hline \multicolumn{9}{|c|}{ JOHN MARTIN RESERVOIR (Site R4) } \\
\hline Mallard & $<1$ & 6.9 & 2,310 & $<4$ & 756 & 13 & 0.08 & 2 \\
\hline American coot & $<1$ & 22.5 & 1,020 & $<4$ & 681 & 15 & 0.13 & 3 \\
\hline Killdeer & $<1$ & 19.9 & 1,040 & $<4$ & 797 & 17 & 0.24 & 2 \\
\hline Killdeer & $<1$ & 13 & 466 & $<4$ & 848 & 18 & 0.15 & 2 \\
\hline Geometric mean & -- & 16.1 & 696 & -- & 822 & 17 & 0.19 & 2 \\
\hline \multicolumn{9}{|c|}{ LAKE MCKINNEY (Site R5) } \\
\hline Mallard & $<1$ & 15 & 9,030 & $<4$ & 575 & 10 & 0.08 & 5 \\
\hline Mallard & $<1$ & 31.9 & 3,600 & $<4$ & 642 & 11 & 0.12 & 2 \\
\hline Mallard & $<1$ & 147 & 2,620 & $<4$ & 703 & 15 & 0.14 & 2 \\
\hline Geometric mean & -- & 41.3 & 4,400 & -- & 638 & 12 & 0.11 & 3 \\
\hline American coot & $<1$ & 18 & 991 & $<4$ & 630 & 7.9 & 0.12 & 3.5 \\
\hline American coot & $<1$ & 31.7 & 5,700 & $<4$ & 686 & 9.3 & 0.39 & 6.1 \\
\hline Geometric mean & -- & 23.9 & 2,380 & -- & 657 & 8.6 & 0.22 & 4.6 \\
\hline Killdeer & $<1$ & 25.6 & 1,160 & $<4$ & 800 & 18 & 0.29 & 3 \\
\hline Killdeer & $<1$ & 23.4 & 908 & $<4$ & 764 & 14 & 0.22 & 2 \\
\hline Geometric mean & -- & 24.5 & 1,030 & -- & 782 & 16 & 0.25 & 2 \\
\hline Northern shoveler & $<1$ & 49.6 & 1,500 & $<4$ & 334 & 8.7 & 1.13 & 2 \\
\hline Blue-winged teal & $<1$ & 41.6 & 2,400 & $<4$ & 730 & 16 & 2.4 & 3 \\
\hline Blue-winged teal & $<1$ & 41.9 & 1,060 & $<4$ & 652 & 12 & 0.26 & 3.2 \\
\hline Blue-winged teal & $<1$ & 127 & 1,570 & $<4$ & 828 & 14 & 3.0 & 4.3 \\
\hline Geometric mean & -- & 60.5 & 1,590 & -- & 733 & 14 & 1.2 & 3.5 \\
\hline
\end{tabular}

\begin{tabular}{|c|c|c|c|c|c|c|c|}
\hline \multirow{2}{*}{ Species } & \multicolumn{7}{|c|}{ Concentration in micrograms per gram dry weight } \\
\hline & Nickel & Selenium & Silver & Strontium & Thallium & Vanadium & $\overline{\text { Zinc }}$ \\
\hline & \multicolumn{7}{|c|}{ PUEBLO RESERVOIR (Site R1) } \\
\hline Mallard & $<1$ & 21 & $<2$ & 1.6 & $<5$ & 0.5 & 91.4 \\
\hline Mallard & $<1$ & 43 & $<2$ & 0.48 & $<5$ & 0.4 & 140 \\
\hline Mallard & $<1$ & 21 & $<2$ & 0.2 & $<5$ & $<0.3$ & 138 \\
\hline Mallard & $<1$ & 23 & $<2$ & 0.2 & $<5$ & 0.3 & 195 \\
\hline Mallard & $<1$ & 18 & $<2$ & 0.2 & $<5$ & 0.4 & 159 \\
\hline Mallard & $<1$ & 27 & $<2$ & 0.2 & $<5$ & 0.4 & 159 \\
\hline Geometric mean & -- & 24 & -- & 0.33 & -- & 0.3 & 143 \\
\hline Killdeer & $<1$ & 45 & $<2$ & 0.53 & $<5$ & $<0.3$ & 93.6 \\
\hline Killdeer & $<1$ & 30 & $<2$ & 0.34 & $<5$ & $<0.3$ & 81.8 \\
\hline Geometric mean & -- & 36.7 & -- & 0.42 & -- & -- & 87.5 \\
\hline
\end{tabular}


Table 14.--Trace-element concentrations in adult livers from individuals or composite samples of waterbirds collected at reservoir sites in the study area, June 7-10, 1988--Continued

\begin{tabular}{|c|c|c|c|c|c|c|c|}
\hline \multirow{2}{*}{ Species } & \multicolumn{7}{|c|}{ Concentration in micrograms per gram dry weight } \\
\hline & Nickel & Selenium & Silver & Strontium & Thallium & Vanadium & $\overline{\text { Zinc }}$ \\
\hline & \multicolumn{7}{|c|}{ LAKE MEREDITH (Site R2) } \\
\hline Mallard & $<1$ & 21 & $<2$ & 0.34 & $<5$ & $<0.3$ & 93.5 \\
\hline Mallard & $<1$ & 25 & $<2$ & 0.82 & $<5$ & 0.7 & 160 \\
\hline Mallard & $<1$ & 19 & $<2$ & 0.48 & $<5$ & $<0.3$ & 104 \\
\hline Mallard & $<1$ & 25 & $<2$ & 1.3 & $<5$ & $<0.3$ & 183 \\
\hline Mallard & $<1$ & 20 & $<2$ & 0.3 & $<5$ & 0.7 & 173 \\
\hline Mallard & $<1$ & 22 & $<2$ & 3.2 & $<5$ & $<0.3$ & 75.9 \\
\hline Geometric mean & -- & 22 & -- & 0.74 & - & - & 125 \\
\hline American coot & $<1$ & 25 & $<2$ & 0.54 & $<5$ & 1.9 & 160 \\
\hline American coot & $<1$ & 2.7 & $<2$ & 0.2 & $<5$ & 0.8 & 77.5 \\
\hline American coot & $<1$ & 33 & $<2$ & 0.49 & $<5$ & 1.1 & 113 \\
\hline American coot & $<1$ & 16 & $<2$ & 1.2 & $<5$ & 1.5 & 121 \\
\hline American coot & $<1$ & 17 & $<2$ & 0.53 & $<5$ & 0.3 & 112 \\
\hline American coot & $<1$ & 22 & $<2$ & 0.67 & $<4$ & $<0.3$ & 123 \\
\hline Geometric mean & -- & 15 & -- & 0.53 & -- & 0.70 & 115 \\
\hline Killdeer & $<1$ & 41 & $<2$ & 1.0 & $<5$ & $<0.3$ & 78.1 \\
\hline Killdeer & $<1$ & 43 & $<2$ & 0.76 & $<5$ & $<0.3$ & 85.5 \\
\hline Geometric mean & -- & 42 & -- & 0.87 & -- & -- & 81.7 \\
\hline \multirow[t]{2}{*}{ Black-necked stilt } & $<1$ & 56 & $<\dot{2}$ & 0.3 & $<5$ & $<0.3$ & 100 \\
\hline & \multicolumn{7}{|c|}{ GREAT PLAINS RESERVOIRS (Site R3) } \\
\hline Mallard & $<1$ & 33 & $<2$ & 0.38 & $<5$ & $<0.3$ & 115 \\
\hline Killdeer & $<1$ & 20 & $<2$ & 0.58 & $<5$ & $<0.3$ & 73.9 \\
\hline Killdeer & $<1$ & 24 & $<2$ & 0.63 & $<5$ & $<0.3$ & 85.0 \\
\hline \multirow[t]{2}{*}{ Geometric mean } & -- & 22 & -- & 0.60 & -- & -- & 79.3 \\
\hline & \multicolumn{7}{|c|}{ JOHN MARTIN RESERVOIR (Site R4) } \\
\hline Mallard & $<1$ & 11 & $<2$ & 1.6 & $<5$ & $<0.3$ & 97.8 \\
\hline American coot & $<1$ & 23 & $<2$ & 0.48 & $<4$ & $<0.3$ & 118 \\
\hline Killdeer & $<1$ & $4 \dot{3}$ & $<2$ & 1.6 & $<5$ & $<0.3$ & 76.5 \\
\hline Killdeer & $<1$ & 25 & $<2$ & 1.2 & $<5$ & $<0.3$ & 75.5 \\
\hline \multirow[t]{2}{*}{ Geometric mean } & -- & 33 & -- & 1.4 & -- & -- & 76.0 \\
\hline & \multicolumn{7}{|c|}{ LAKE MCKINNEY (Site R5) } \\
\hline Mallard & $<1$ & 12 & $<2$ & 0.66 & $<5$ & $<0.3$ & 75.9 \\
\hline Mallard & $<1$ & 9.8 & $<2$ & 0.79 & $<5$ & $<0.3$ & 88.2 \\
\hline Mallard & $<1$ & 7.8 & $<2$ & 0.3 & $<5$ & $<0.3$ & 150 \\
\hline Geometric mean & -- & 9.7 & -- & 0.54 & -- & -- & 100 \\
\hline American coot & $<1$ & 21 & $<2$ & 2.1 & $<4$ & 0.9 & 136 \\
\hline American coot & $<1$ & 7 & $<2$ & 0.8 & $<4$ & 1.0 & 232 \\
\hline Geometric mean & -- & 12 & -- & 1.3 & -- & 1.0 & 178 \\
\hline Killdeer & $<1$ & 9.9 & $<2$ & 1.0 & $<5$ & $<0.3$ & 109 \\
\hline Killdeer & $<1$ & 10 & $<2$ & 0.63 & $<5$ & $<0.3$ & 91.5 \\
\hline Geometric mean & -- & 9.9 & -- & 0.79 & -- & -- & 99.9 \\
\hline Northern shoveler & $<1$ & 2.7 & $<2$ & 0.24 & $<4$ & 0.4 & 43.7 \\
\hline Blue-winged teal & $<1$ & 12 & $<2$ & 1.1 & $<4$ & 0.5 & 128 \\
\hline Blue-winged teal & $<1$ & 15 & $<2$ & 0.43 & $<4$ & $<0.3$ & 74.9 \\
\hline Blue-winged teal & $<1$ & 29 & $<2$ & 3.8 & $<4$ & $<0.3$ & 123 \\
\hline Geometric mean & & 17 & -- & 1.2 & -- & -- & 106 \\
\hline
\end{tabular}


Table 15.--Trace-element concentrations in adult livers and breast muscles from individual samples of waterbirds collected at reservoir sites in the study area, October 7-13, 1988

[Sanpling sites are shown in figure 7; codes for sex are M-male, F-female, and U-unknown; data for muscle follow data for liver from the same individual; <, less than; --, geometric mean not calculated]

\begin{tabular}{|c|c|c|c|c|c|c|}
\hline Species & $\begin{array}{l}\text { Bird } \\
\text { identi- }\end{array}$ & Sex & Tissue & $\begin{array}{l}\text { Percent } \\
\text { mois - }\end{array}$ & $\begin{array}{l}\text { Concentrations in } \\
\text { micrograms per gram dry weight }\end{array}$ & \\
\hline & $\begin{array}{l}\text { fication } \\
\text { number }\end{array}$ & & & ture & Aluminum Arsenic Barium Beryllium & Boron \\
\hline
\end{tabular}

\begin{tabular}{ll}
$\begin{array}{l}\text { Mallard } \\
\text { Mallard }\end{array}$ & $\begin{array}{l}\mathrm{R} 1-1 \\
\mathrm{R} 1-1\end{array}$ \\
\hline Killdeer & $\mathrm{R} 1-2$ \\
\hline $\begin{array}{l}\text { Blue-winged teal } \\
\text { Blue-winged teal }\end{array}$ & $\mathrm{R} 1-3$ \\
& $\mathrm{R} 1-3$ \\
& \\
& \\
Mallard & $\mathrm{R} 2-1$ \\
Mallard & $\mathrm{R} 2-1$ \\
& $\mathrm{R} 2-2$ \\
American coot & $\mathrm{R} 2-2$ \\
American coot & $\mathrm{R} 2-3$ \\
American coot & $\mathrm{R} 2-3$ \\
American coot & $\mathrm{R} 2-4$ \\
American coot & $\mathrm{R} 2-5$ \\
American coot & \\
$\quad$ Geometric mean &
\end{tabular}

PUEBLO RESERVOIR (Site R1)

Eared grebe

R2-1
R2-1
R2-2
R2-2
R2-3
R2-3
R2-4
R2-5

\section{LAKE MEREDITH (Site R2)}

ared grebe

American coot
American coot
American coot
American coot
American coot
American coot
American coot
Geometric mean
Double-crested cormorant
Double-crested cormorant Geometric mean

Eared grebe

R2-6

F
F
M
M
M
M
U
F

$\begin{array}{ll}\text { Liver } & 72.6 \\ \text { Muscle } & 74.2 \\ & \\ \text { Liver } & 69.9 \\ \text { Muscle } & 68.2 \\ \text { Liver } & 71.1 \\ \text { Muscle } & 71.1 \\ \text { Liver } & 69.4 \\ \text { Liver } & 67.2\end{array}$

$<7.30$

4.30

0.03
$<0.39$

$<3.65$

$<1.94$

$<0.36$

$<0.19$

$<3.65$

8.24

$<0.35$

$<1.66$

$<0.17$

$<1.57$

4.28
$<3.46$

$<0.35$

4.36

$<0.54$

$<1.73$

$<0.16$

$<1.73$

$<0.17$

$<0.38$

$<1.62$

$<0.17$

6.71

0.50

$<3.05$

$<0.30$

$<1.94$

Liver -- $\quad 5.83$

Muscle

5.83

Liver $\quad 72.3 \quad<7.22$
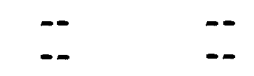

0.14

$<3.61$

$<0.36$

$<1.66$

$<1.57$

2.66

$<1.73$

$<3.27$

$<3.05$

JOHN MARTIN RESERVOIR (Site R4)

R4-1
R4-1
R4-2
R4-2
R4-3
R4-4
R4-5

\section{Liver $\quad 73.5$}

7.32

$<0.38$

$<1.89$

$<0.19$

$<0.17$

23.7

$<0.34$

$\begin{array}{ll}\text { Muscle } & 70.4 \\ \text { Liver } & 69.2\end{array}$

4.22

$<0.32$

Muscle 71.3

17.4

$<0.35$

Liver $\quad 67.7$

$<3.10$

$<0.31$

Liver $\quad 71.7$

$<7$

Liver $\quad 72.3$

14.9

0.44
$<0.36$

$<1.69$

$<1.62$

$<0.16$

$<1.74$

$<1.55$

$<0.17$

$<0.15$

$<4$

$<0.35$

$<1.81$

$<0.18$

$<1.89$

$<1.69$

Liver -- $\quad 4.78$

Muscle -- $\quad 20.3$

R4-6

Liver

71.3

$<6.97$

0.05

$<3.48$

$<0.35$

$<3.48$

R4-7

Liver

72.4

$<3.62$

$<0.36$

$<1.81$

$<0.18$

$<1.81$

Liver

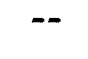

0.09

Liver $\quad 70.2 \quad<6.71$

$<0.06$

$<3.36$

$<0.34$

$<3.36$

LAKE MCKİNNEY (Site R5)

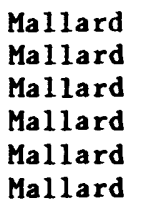

Geometric mean
R5-1

R5-1

R5-2

R5-2

R5-3

R5-3

$\begin{array}{lll}\text { Liver } & 78.6 & <9.35 \\ \text { Muscle } & 74.1 & 10.2 \\ \text { Liver } & 65.5 & <2.90 \\ \text { Muscle } & 72.1 & <3.58 \\ \text { Liver } & 68.0 & <3.12 \\ \text { Muscle } & 72.5 & 5.85\end{array}$

Liver

Muscle

$\mathbf{F}$
$\mathbf{F}$
$\mathbf{F}$
$\mathbf{M}$
$\mathbf{M}$

$<0.15$
$<0.39$
$<0.29$
$<0.36$
$<0.31$
$<0.36$

$<4.67$
$<1.93$
$<1.45$
$<1.79$
$<1.56$
$<1.82$

$<0.47$

$<0.19$

$<0.14$

$<0.18$

$<0.16$

$<1.74$

1.73

$<4$

$\begin{array}{lll}\text { Liver } & -- & - \\ \text { Muscle } & -- & 4.75\end{array}$


Table 15.--Trace-element concentrations in adult livers and breast muscles from individual samples of waterbirds collected at reservoir sites in the study area; October 7-13, 1988--Continued

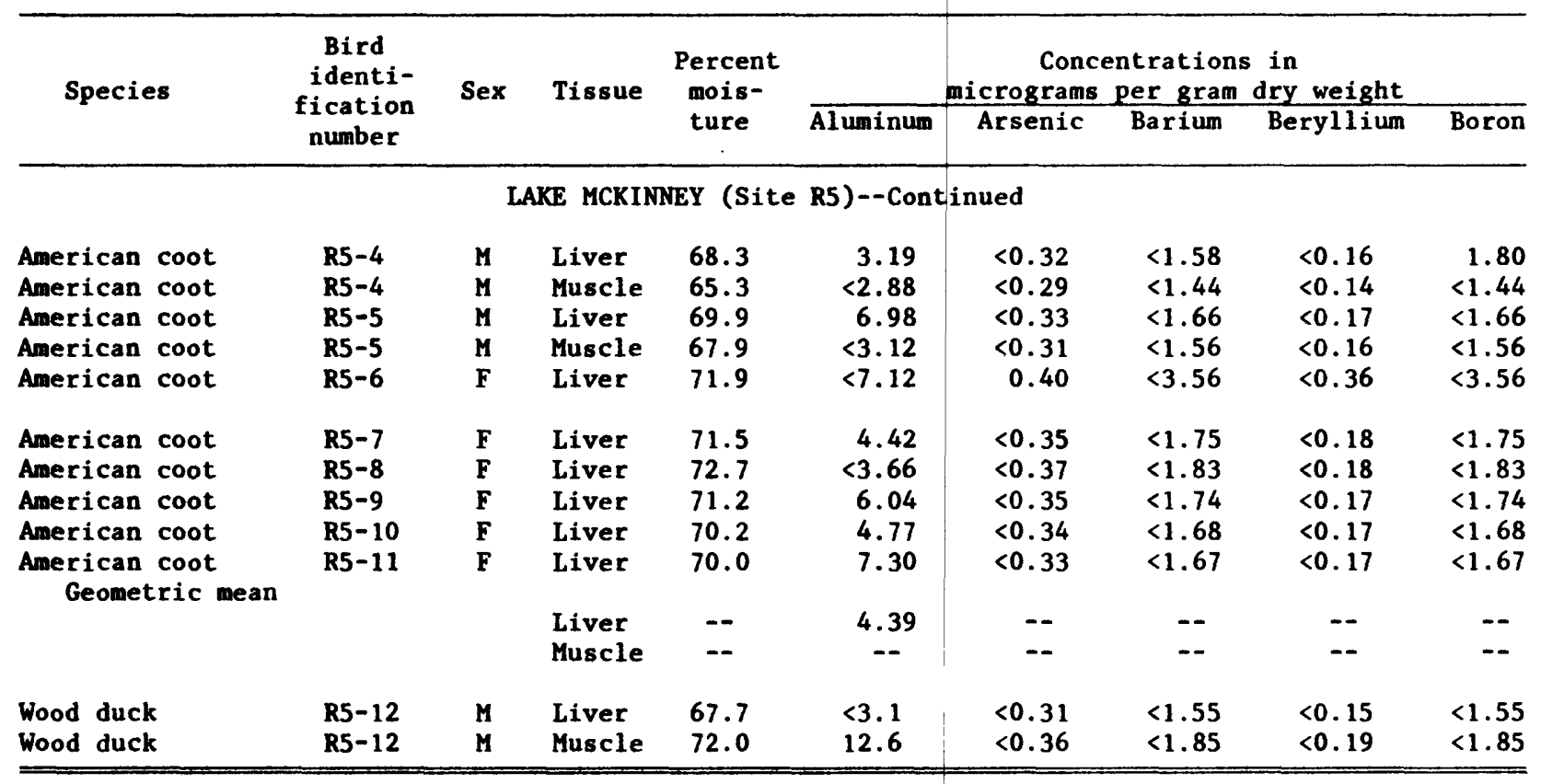

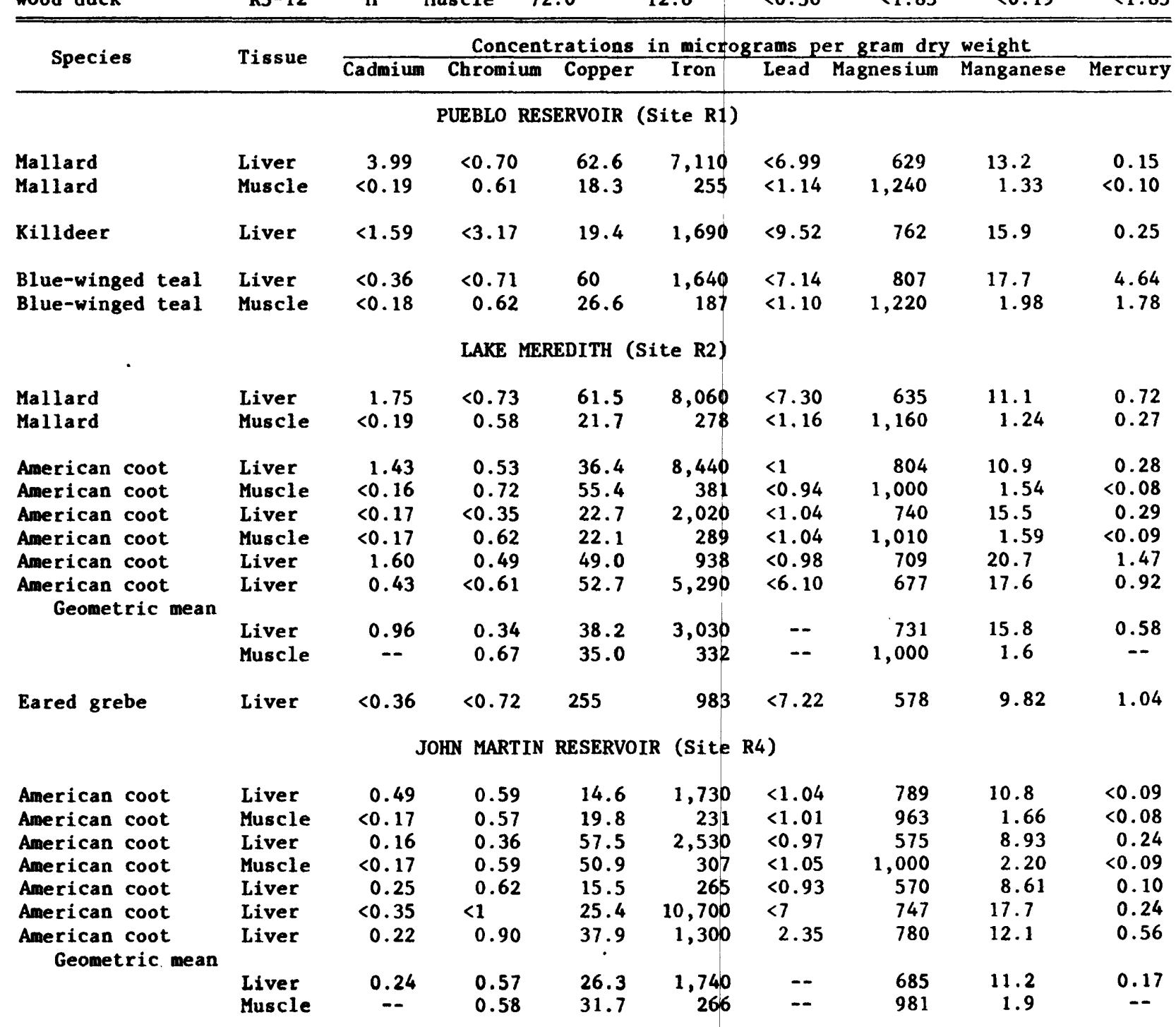


Table 15.--Trace-element concentrations in adult livers and breast muscles from individual samples of waterbirds collected at reservoir sites in the study area, October 7-13, 1988--Continued

\begin{tabular}{|c|c|c|c|c|c|c|c|c|c|}
\hline \multirow{2}{*}{ Species } & \multirow{2}{*}{ Tissue } & \multicolumn{8}{|c|}{ Concentrations in micrograms per gram dry weight } \\
\hline & & Cadmium & Chromium & Copper & Iron & Lead & Magnesium & Manganese & Mercury \\
\hline \multicolumn{10}{|c|}{ JOHN MARTIN RESERVOIR (Site R4)--Continued } \\
\hline $\begin{array}{l}\text { Double-crested } \\
\text { cormorant }\end{array}$ & Liver & $<0.35$ & $<0.70$ & 15.7 & 1,900 & $<6.97$ & 634 & 12.0 & 0.24 \\
\hline \multirow{2}{*}{$\begin{array}{l}\text { Double-crested } \\
\text { cormorant } \\
\text { Geometric mean }\end{array}$} & Liver & 0.25 & 0.72 & 12.6 & 871 & $<1.09$ & 703 & 12.6 & 3.32 \\
\hline & Liver & 0.21 & 0.50 & 14.1 & 1,290 & -- & 668 & 12.3 & 0.89 \\
\hline Eared grebe & Liver & $<0.34$ & $<0.67$ & 24.0 & 3,820 & $<6.71$ & 685 & 18.3 & 1.74 \\
\hline \multicolumn{10}{|c|}{ LAKE MCKINNEY (Site R5) } \\
\hline $\begin{array}{l}\text { Mallard } \\
\text { Mallard } \\
\text { Mallard } \\
\text { Mallard } \\
\text { Mallard } \\
\text { Mallard }\end{array}$ & $\begin{array}{l}\text { Liver } \\
\text { Muscle } \\
\text { Liver } \\
\text { Muscle } \\
\text { Liver } \\
\text { Muscle }\end{array}$ & $\begin{array}{r}<0.65 \\
<0.19 \\
0.55 \\
<0.18 \\
0.41 \\
<0.18\end{array}$ & $\begin{array}{r}<0.93 \\
0.66 \\
0.40 \\
0.61 \\
0.44 \\
0.91\end{array}$ & $\begin{array}{l}56.9 \\
33.1 \\
46.1 \\
18.5 \\
21.9 \\
24.7\end{array}$ & $\begin{array}{r}2,070 \\
350 \\
1,670 \\
168 \\
1,920 \\
403\end{array}$ & $\begin{array}{l}<9.35 \\
<1.16 \\
<0.87 \\
<1.08 \\
<0.94 \\
<1.09\end{array}$ & $\begin{array}{r}925 \\
1,020 \\
443 \\
1,000 \\
484 \\
1,640\end{array}$ & $\begin{array}{l}16.7 \\
1.78 \\
6.46 \\
1.65 \\
4.67 \\
2.47\end{array}$ & $\begin{array}{l}0.92 \\
0.17 \\
0.23 \\
0.18 \\
0.29 \\
0.17\end{array}$ \\
\hline $\begin{array}{l}\text { Mallard } \\
\text { Geometric mean }\end{array}$ & $\begin{array}{l}\text { Liver } \\
\text { Muscle }\end{array}$ & 0.42 & $\begin{array}{l}0.43 \\
0.72\end{array}$ & $\begin{array}{l}38.6 \\
24.7\end{array}$ & $\begin{array}{r}1,870 \\
287\end{array}$ & -- & $\begin{array}{r}583 \\
1,190\end{array}$ & $\begin{array}{l}7.96 \\
1.94\end{array}$ & $\begin{array}{l}0.39 \\
0.17\end{array}$ \\
\hline $\begin{array}{l}\text { American coot } \\
\text { American coot } \\
\text { American coot } \\
\text { American coot } \\
\text { American coot }\end{array}$ & $\begin{array}{l}\text { Liver } \\
\text { Muscle } \\
\text { Liver } \\
\text { Muscle } \\
\text { Liver }\end{array}$ & $\begin{array}{r}1.51 \\
<0.14 \\
1.33 \\
<0.16 \\
<0.36\end{array}$ & $\begin{array}{r}0.73 \\
0.34 \\
<0.33 \\
0.62 \\
<0.71\end{array}$ & $\begin{array}{l}43.2 \\
41.2 \\
40.2 \\
52.8 \\
13.0\end{array}$ & $\begin{array}{r}7,790 \\
257 \\
22,300 \\
110 \\
5,550\end{array}$ & $\begin{array}{l}<0.95 \\
<0.86 \\
<1 \\
<0.93 \\
<7.12\end{array}$ & $\begin{array}{l}571 \\
804 \\
621 \\
866 \\
747\end{array}$ & $\begin{array}{l}12.1 \\
1.90 \\
17.3 \\
1.78 \\
17.7\end{array}$ & $\begin{array}{r}0.10 \\
<0.07 \\
1.07 \\
0.22 \\
0.24\end{array}$ \\
\hline $\begin{array}{l}\text { American coot } \\
\text { American coot } \\
\text { American coot } \\
\text { American coot } \\
\text { American coot }\end{array}$ & $\begin{array}{l}\text { Liver } \\
\text { Liver } \\
\text { Liver } \\
\text { Liver } \\
\text { Liver }\end{array}$ & $\begin{array}{l}0.95 \\
0.37 \\
0.94 \\
2.48 \\
0.17\end{array}$ & $\begin{array}{r}0.49 \\
0.51 \\
<0.35 \\
<0.34 \\
<0.33\end{array}$ & $\begin{array}{l}26.2 \\
35.6 \\
23.4 \\
36.2 \\
15.6\end{array}$ & $\begin{array}{r}6,320 \\
10,000 \\
3,510 \\
13,000 \\
380\end{array}$ & $\begin{array}{l}<1.05 \\
<1.10 \\
<1.04 \\
<1.01 \\
<1.0\end{array}$ & $\begin{array}{l}649 \\
670 \\
500 \\
658 \\
397\end{array}$ & $\begin{array}{c}12.8 \\
14.7 \\
8.51 \\
15.7 \\
9.05\end{array}$ & $\begin{array}{l}0.76 \\
0.58 \\
0.39 \\
0.23 \\
0.44\end{array}$ \\
\hline $\begin{array}{l}\text { American coot } \\
\text { Geometric mean }\end{array}$ & $\begin{array}{l}\text { Liver } \\
\text { Muscle }\end{array}$ & $\begin{array}{c}0.69 \\
--\end{array}$ & $\begin{array}{l}0.29 \\
0.46\end{array}$ & $\begin{array}{l}26.9 \\
46.6\end{array}$ & $\begin{array}{r}5,660 \\
168\end{array}$ & $\begin{array}{l}-- \\
--\end{array}$ & $\begin{array}{l}592 \\
834\end{array}$ & $\begin{array}{l}13.0 \\
1.84\end{array}$ & $\begin{array}{l}0.38 \\
0.09\end{array}$ \\
\hline Wood duck & $\begin{array}{l}\text { Liver } \\
\text { Muscle }\end{array}$ & $\begin{array}{l}<0.15 \\
<0.19\end{array}$ & $\begin{array}{l}0.50 \\
0.78\end{array}$ & $\begin{array}{l}23.1 \\
17.3\end{array}$ & $\begin{array}{r}1,540 \\
240\end{array}$ & $\begin{array}{l}<0.93 \\
<1.11\end{array}$ & $\begin{array}{r}591 \\
1,140\end{array}$ & $\begin{array}{l}6.56 \\
1.96\end{array}$ & $\begin{array}{r}0.12 \\
<0.09\end{array}$ \\
\hline
\end{tabular}

\begin{tabular}{lll}
\multirow{2}{*}{ Species } & \multirow{2}{*}{ Tissue } & \multicolumn{2}{c}{ Concentration in micrograms per gram dry weight } \\
\cline { 3 - 5 } & & Molybdenum Nickel Selenium Silver Strontium Thallium Vanadium Zinc
\end{tabular}

\begin{tabular}{|c|c|c|c|c|c|c|c|c|c|}
\hline \multicolumn{10}{|c|}{ PUEBLO RESERVOIR (Site R1) } \\
\hline $\begin{array}{l}\text { Mallard } \\
\text { Mallard }\end{array}$ & $\begin{array}{l}\text { Liver } \\
\text { Muscle }\end{array}$ & $\begin{array}{r}4.27 \\
<1.90\end{array}$ & $\begin{array}{l}<2.80 \\
<1.52\end{array}$ & $\begin{array}{r}29.7 \\
6.8\end{array}$ & $\begin{array}{l}<3.50 \\
<1.90\end{array}$ & $\begin{array}{l}<0.70 \\
<0.38\end{array}$ & $\begin{array}{l}<0.35 \\
<7.60\end{array}$ & $\begin{array}{l}<3.50 \\
<1.9\end{array}$ & $\begin{array}{l}233 \\
43.2\end{array}$ \\
\hline Killdeer & Liver & $<15.9$ & $<12.7$ & 7.0 & $<15.9$ & $<3.17$ & $<63.5$ & $<15.9$ & 100 \\
\hline $\begin{array}{l}\text { Blue-winged teal } \\
\text { Blue-winged teal }\end{array}$ & $\begin{array}{l}\text { Liver } \\
\text { Muscle }\end{array}$ & $\begin{array}{l}<3.57 \\
<1.83\end{array}$ & $\begin{array}{r}<2.86 \\
6.78\end{array}$ & $\begin{array}{l}6.4 \\
1.5\end{array}$ & $\begin{array}{l}<3.57 \\
<1.83\end{array}$ & $\begin{array}{r}<0.71 \\
0.44\end{array}$ & $\begin{array}{l}<0.36 \\
<7.33\end{array}$ & $\begin{array}{l}<3.57 \\
<1.83\end{array}$ & $\begin{array}{r}145 \\
52.9\end{array}$ \\
\hline \multicolumn{10}{|c|}{ LAKE MEREDITH (Site R2) } \\
\hline $\begin{array}{l}\text { Mallard } \\
\text { Mallard }\end{array}$ & $\begin{array}{l}\text { Liver } \\
\text { Muscle }\end{array}$ & $\begin{array}{l}<3.65 \\
<1.94\end{array}$ & $\begin{array}{l}<2.92 \\
<1.55\end{array}$ & $\begin{array}{r}28.5 \\
6.2\end{array}$ & $\begin{array}{l}<3.65 \\
<1.94\end{array}$ & $\begin{array}{l}<0.73 \\
<0.39\end{array}$ & $\begin{array}{l}<0.36 \\
<7.75\end{array}$ & $\begin{array}{l}<3.65 \\
<1.94\end{array}$ & $\begin{array}{r}124 \\
41.4\end{array}$ \\
\hline
\end{tabular}


Table 15.--Trace-element concentrations in adult livers and breast muscles from individual samples of waterbirds collected at reservoir sites in the study area, October 7-13, 1988--Continued

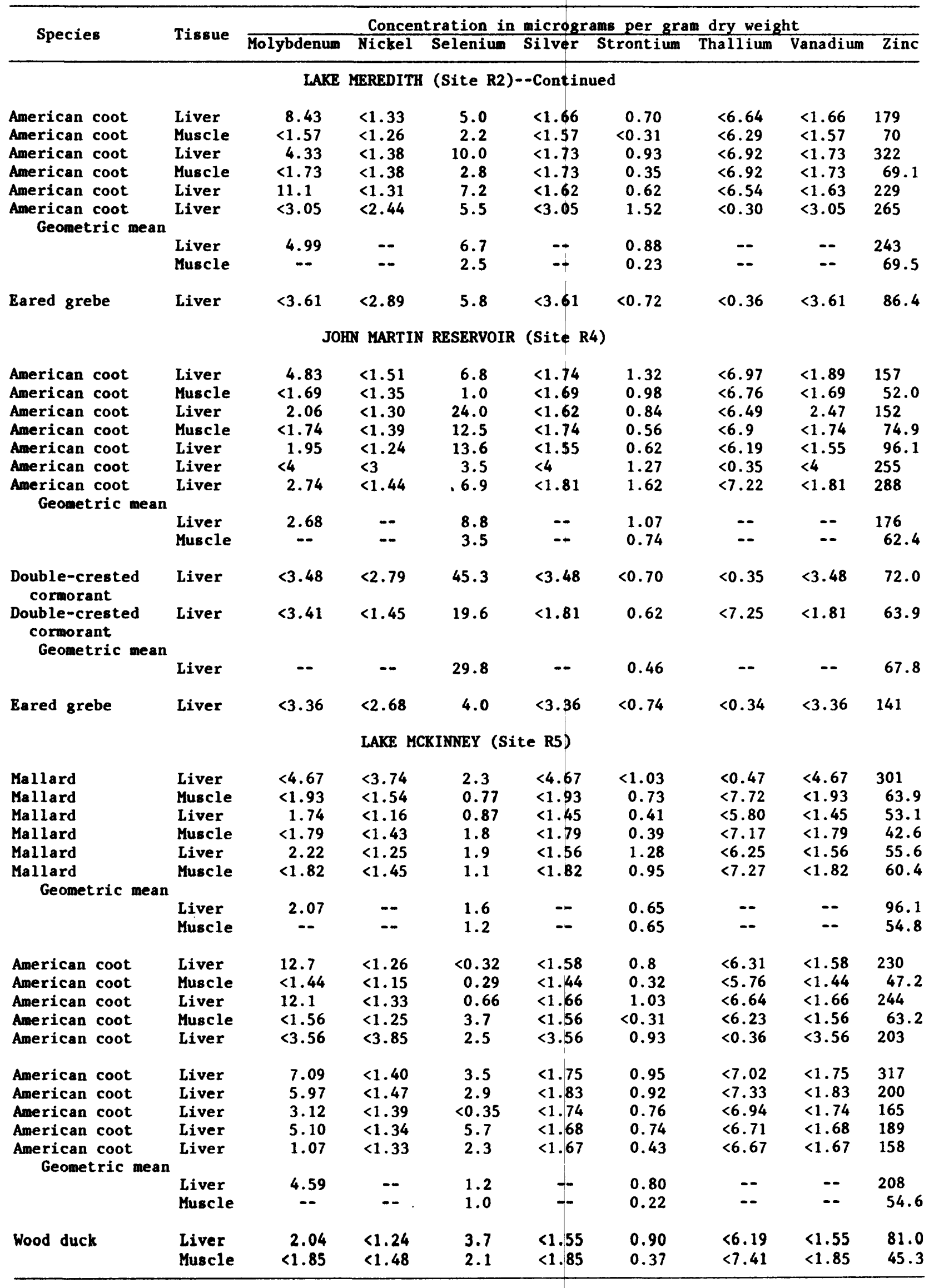


Table 16.--Trace-element concentrations in individuals or composite samples of livers and whole bodies of juveniles, whole nestlings and eggs of waterbirds and passerines collected at reservoir sites in the study area, June 7-10, 1988

[Sampling sites are shown in figure 7; codes for type of sample are I-individual, and C-composite; samples of nestlings and eggs originated from separate nests; <, less than; --, geometric mean not calculated]

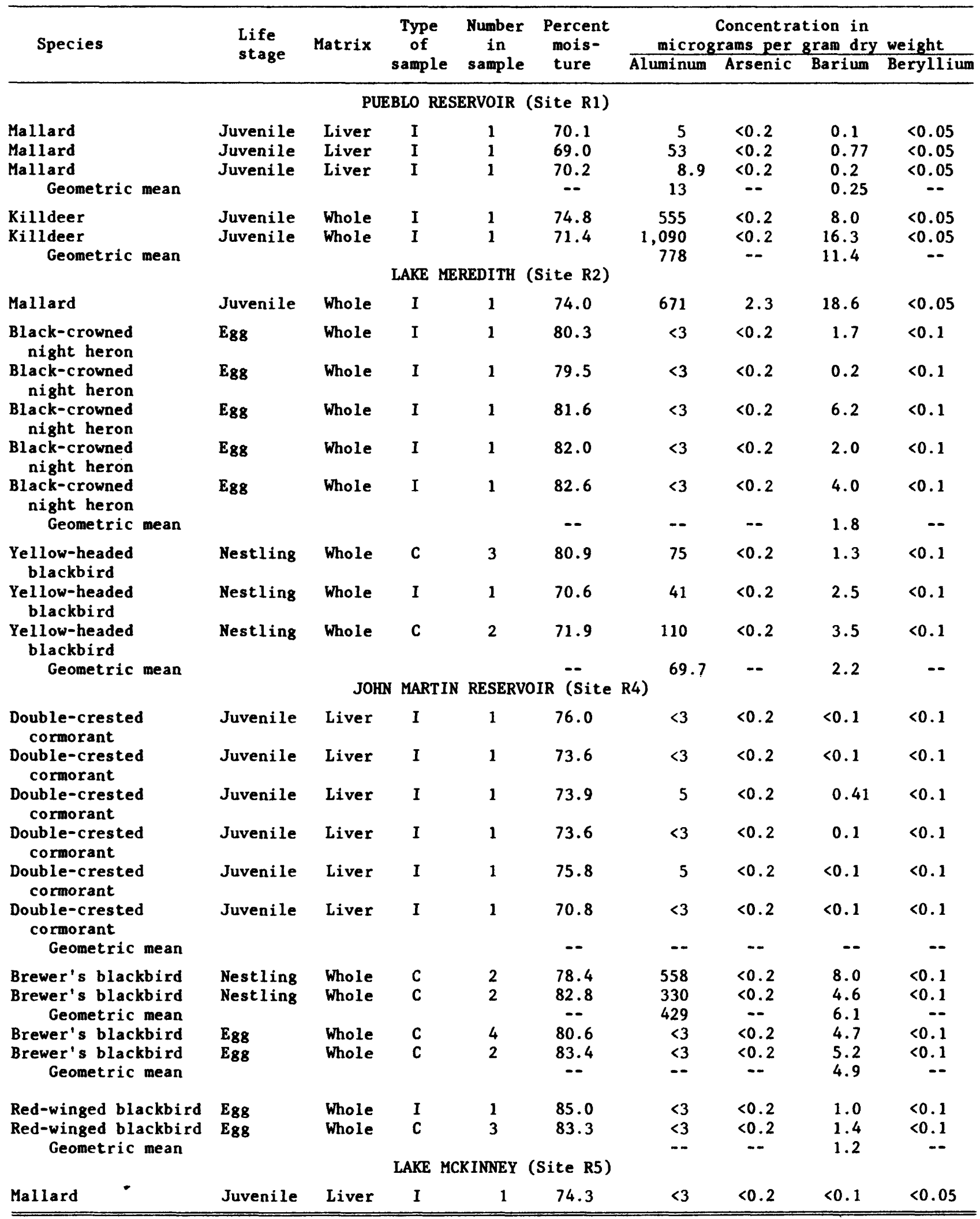


Table 16.--Trace-element concentrations in individuals or composite samples of livers and whole bodies of juveniles, whole nestlings and eggs of waterbirds and passerines collected at reservoir sites in the study area, Jume 7-10, 1988--Continued

\begin{tabular}{|c|c|c|c|c|c|c|c|c|c|}
\hline \multirow{2}{*}{ Species } & \multicolumn{9}{|c|}{ Concentration in micrograms per gram dry weight } \\
\hline & Boron & Cadmium & Chromium & Copper & Iron & Lead & Magnesium & Manganese & Mercury \\
\hline \multicolumn{10}{|c|}{ PUEBLO RESERVOIR (Site R1) } \\
\hline $\begin{array}{l}\text { Mallard } \\
\text { Mallard } \\
\text { Mallard } \\
\quad \text { Geometric mean }\end{array}$ & $\begin{array}{l}<2 \\
<2 \\
<2 \\
--\end{array}$ & $\begin{array}{l}<0.4 \\
<0.4 \\
<0.3 \\
--\end{array}$ & $\begin{array}{l}<1 \\
<1 \\
<1 \\
--\end{array}$ & $\begin{array}{l}8.3 \\
14 \\
20.7 \\
13.4\end{array}$ & $\begin{array}{r}793 \\
962 \\
1,010 \\
917\end{array}$ & $\begin{array}{l}<4 \\
<4 \\
<4 \\
--\end{array}$ & $\begin{array}{l}807 \\
827 \\
835 \\
823\end{array}$ & $\begin{array}{l}13 \\
14 \\
11 \\
13\end{array}$ & $\begin{array}{l}0.06 \\
0.09 \\
0.09 \\
0.08\end{array}$ \\
\hline $\begin{array}{l}\text { Killdeer } \\
\text { Killdeer } \\
\text { Geometric mean }\end{array}$ & $\begin{array}{l}<2 \\
<2 \\
--\end{array}$ & $\begin{array}{l}<0.3 \\
<0.3 \\
--\end{array}$ & $\begin{array}{l}2 \\
10 \\
4.5\end{array}$ & $\begin{array}{l}6.2 \\
6.8 \\
6.5\end{array}$ & $\begin{array}{r}754 \\
2,370 \\
1,340\end{array}$ & $\begin{array}{l}<4 \\
<4 \\
--\end{array}$ & $\begin{array}{l}1,240 \\
1,580 \\
1,400\end{array}$ & $\begin{array}{l}32.6 \\
69.6 \\
47.6\end{array}$ & $\begin{array}{l}0.08 \\
0.06 \\
0.07\end{array}$ \\
\hline \multicolumn{10}{|c|}{ LAKE MEREDITH (Site R2) } \\
\hline Mallard & $<2$ & $<0.4$ & 3 & 5.5 & 2,140 & $<4$ & 1,050 & 26.4 & 0.02 \\
\hline $\begin{array}{l}\text { Black-crowned } \\
\text { night heron }\end{array}$ & $<2$ & $<0.2$ & $<1$ & 2.9 & 82 & $<4$ & 575 & 1.5 & 0.71 \\
\hline $\begin{array}{l}\text { Black-crowned } \\
\text { night heron }\end{array}$ & $<2$ & $<0.2$ & $<1$ & 4.2 & 94 & $<4$ & 465 & 2.2 & 1.02 \\
\hline $\begin{array}{l}\text { Black-crowned } \\
\text { night heron }\end{array}$ & $<2$ & $<0.2$ & $<1$ & 4.0 & 96 & $<4$ & 588 & 2.4 & 0.18 \\
\hline $\begin{array}{l}\text { Black-crowned } \\
\text { night heron }\end{array}$ & $<2$ & $<0.2$ & $<1$ & 3.5 & 90 & $<4$ & 598 & 1.8 & 0.42 \\
\hline $\begin{array}{l}\text { Black-crowned } \\
\text { night heron }\end{array}$ & $<2$ & $<0.2$ & $<1$ & 3.9 & 134 & $<4$ & $639^{\circ}$ & 1.4 & 0.13 \\
\hline Geometric mean & -- & -- & -- & 3.7 & 97.7 & -- & 570 & 1.8 & 0.37 \\
\hline $\begin{array}{l}\text { Yellow-headed } \\
\text { blackbird }\end{array}$ & $<2$ & 0.3 & $<1$ & 9.9 & 320 & $<4$ & 1,200 & 11 & 0.03 \\
\hline $\begin{array}{l}\text { Yellow-headed } \\
\text { blackbird }\end{array}$ & $<2$ & $<0.2$ & $<1$ & 6.3 & 215 & $<4$ & 1,160 & 5.6 & 0.05 \\
\hline $\begin{array}{l}\text { Yellow-headed } \\
\text { blackbird }\end{array}$ & $<2$ & $<0.2$ & 1 & 7.3 & 809 & $<4$ & 1,140 & 9.5 & 0.04 \\
\hline Geometric mean & -- & -- & -- & 7.7 & 382 & -- & 1,300 & 8.4 & 0.04 \\
\hline \multicolumn{10}{|c|}{ JOHN MARTIN RESERVOIR (Site R4) } \\
\hline $\begin{array}{l}\text { Double-crested } \\
\text { cormorant }\end{array}$ & $<2$ & $<0.2$ & $<1$ & 10 & 371 & $<4$ & 839 & 14 & 0.01 \\
\hline $\begin{array}{l}\text { Double-crested } \\
\text { cormorant }\end{array}$ & $<2$ & $<0.2$ & $<1$ & 23.4 & 489 & $<4$ & 823 & 15 & 0.09 \\
\hline $\begin{array}{l}\text { Double-crested } \\
\text { cormorant }\end{array}$ & $<2$ & $<0.2$ & 1 & 20 & 422 & $<4$ & 765 & 15 & 0.12 \\
\hline $\begin{array}{l}\text { Double-crested } \\
\text { cormorant }\end{array}$ & $<2$ & $<0.2$ & $<1$ & 12 & 1,010 & $<4$ & 809 & 16 & 0.12 \\
\hline $\begin{array}{l}\text { Double-crested } \\
\text { cormorant }\end{array}$ & $<2$ & $<0.2$ & $<1$ & 10 & 444 & $<4$ & 822 & 15 & 0.11 \\
\hline $\begin{array}{l}\text { Double-crested } \\
\text { cormorant }\end{array}$ & $<2$ & $<0.2$ & $<1$ & 16 & 1,470 & $<4$ & 609 & 10 & 0.40 \\
\hline Geometric mean & -- & -- & -- & 14.4 & 608 & -- & 773 & 14 & 0.09 \\
\hline $\begin{array}{r}\text { Brewer's blackbird } \\
\text { Brewer's blackbird } \\
\text { Geometric mean } \\
\text { Brewer's blackbird } \\
\text { Brewer's blackbird } \\
\text { Geometric mean }\end{array}$ & $\begin{array}{l}<2 \\
<2 \\
-- \\
<2 \\
<2 \\
--\end{array}$ & $\begin{array}{l}<0.2 \\
<0.2 \\
-- \\
<0.2 \\
<0.2 \\
--\end{array}$ & $\begin{array}{l}4.5 \\
2.0 \\
3.0 \\
<1 \\
<1 \\
--\end{array}$ & $\begin{array}{l}7.6 \\
12 \\
9.5 \\
2.0 \\
2.2 \\
2.1\end{array}$ & $\begin{array}{l}660 \\
471 \\
558 \\
199 \\
132 \\
162\end{array}$ & $\begin{array}{l}<4 \\
<4 \\
-- \\
<4 \\
<4 \\
--\end{array}$ & $\begin{array}{r}1,490 \\
1,290 \\
1,390 \\
493 \\
391 \\
439\end{array}$ & $\begin{array}{r}19 \\
15 \\
17 \\
2.5 \\
3.1 \\
2.8\end{array}$ & $\begin{array}{l}0.07 \\
0.03 \\
0.05 \\
0.03 \\
0.04 \\
0.03\end{array}$ \\
\hline $\begin{array}{c}\text { Red-winged blackbird } \\
\text { Red-winged blackbird } \\
\text { Geometric mean }\end{array}$ & $\begin{array}{l}<2 \\
<2 \\
--\end{array}$ & $\begin{array}{l}<0.2 \\
<0.2 \\
--\end{array}$ & $\begin{array}{l}<1 \\
<1 \\
--\end{array}$ & $\begin{array}{l}2.3 \\
3.1 \\
2.7\end{array}$ & $\begin{array}{l}143 \\
159 \\
151\end{array}$ & $\begin{array}{l}<4 \\
<4 \\
--\end{array}$ & $\begin{array}{l}381 \\
425 \\
402\end{array}$ & $\begin{array}{l}4.5 \\
4.0 \\
4.2\end{array}$ & $\begin{array}{l}0.05 \\
0.06 \\
0.05\end{array}$ \\
\hline \multicolumn{10}{|c|}{ LAKE MCKINNEY (Site R5) } \\
\hline Mallard & $<2$ & $<0.3$ & $<1$ & 64.1 & 582 & $<4$ & 780 & 15 & 0.10 \\
\hline
\end{tabular}


Table 16.--Trace-element concentrations in indivicuals or composite samples of livers and whole bodies of juveniles, whole nestlings and eggs of waterbirds and passerines collected at reservoir sites in the study area, June 7-10, 1988--Continued

\begin{tabular}{|c|c|c|c|c|c|c|c|c|}
\hline \multirow{2}{*}{ Species } & \multicolumn{8}{|c|}{ Concentration in micrograms per gram dry weight } \\
\hline & Molybdenum & Nickel & Selenium & Silver & Strontium & Thallium & Vanadium & Zinc \\
\hline \multicolumn{9}{|c|}{ PUEBLO RESERVOIR (Site R1) } \\
\hline Mallard & 2 & $<1$ & 18 & $<2$ & 0.48 & $<5$ & $<0.3$ & 122 \\
\hline Mallard & 2 & $<1$ & 9.2 & $<2$ & 1.5 & $<5$ & $<0.3$ & 110 \\
\hline Mallard & 2 & $<1$ & 10 & $<2$ & 0.48 & $<5$ & $<0.3$ & 145 \\
\hline Geometric mean & 2 & -- & 12 & -- & 0.70 & -- & -- & 125 \\
\hline Killdeer & $<1$ & $<1$ & 12 & $<2$ & 46.1 & $<5$ & 1.7 & 95.9 \\
\hline Killdeer & $<1$ & 5.0 & 8.1 & $<2$ & 57.7 & $<5$ & 5.1 & 110 \\
\hline Geometric mean & -- & 1.6 & 9.9 & -- & 51.6 & - & 2.9 & 103 \\
\hline \multicolumn{9}{|c|}{ LAKE MEREDITH (Site R2) } \\
\hline Mallard & $<1$ & 2.0 & 7.2 & $<2$ & 37.0 & $<5$ & 5.0 & 67.8 \\
\hline $\begin{array}{l}\text { Black-crowned } \\
\text { night heron }\end{array}$ & $<1$ & $<1$ & 7.2 & $<2$ & 14.0 & $<4$ & $<0.3$ & 46.6 \\
\hline $\begin{array}{l}\text { Black-crowned } \\
\text { night heron }\end{array}$ & $<1$ & $<1$ & 4.0 & $<2$ & 5.0 & $<4$ & $<0.3$ & 51.3 \\
\hline $\begin{array}{l}\text { Black-crowned } \\
\text { night heron }\end{array}$ & $<1$ & $<1$ & 7.8 & $<2$ & 15.7 & $<4$ & $<0.3$ & 43.8 \\
\hline $\begin{array}{l}\text { Black-crowned } \\
\text { night heron }\end{array}$ & $<1$ & $<1$ & 6.6 & $<2$ & 11.5 & $<4$ & $<0.3$ & 54.8 \\
\hline $\begin{array}{l}\text { Black-crowned } \\
\text { night heron }\end{array}$ & $<1$ & $<1$ & 7.3 & $<2$ & 14.2 & $<4$ & $<0.3$ & 53.9 \\
\hline Geometric mean & - & -- & 6.4 & -- & 11.2 & -- & -- & 49.9 \\
\hline $\begin{array}{l}\text { Yellow-headed } \\
\text { blackbird }\end{array}$ & $<1$ & $<1$ & 19 & $<2$ & 34.4 & $<4$ & 0.4 & 100 \\
\hline $\begin{array}{c}\text { Yellow-headed } \\
\text { blackbird }\end{array}$ & $<1$ & $<1$ & 13 & $<2$ & 65.0 & $<4$ & $<0.3$ & 103 \\
\hline $\begin{array}{l}\text { Yellow-headed } \\
\text { blackbird }\end{array}$ & $<1$ & $<1$ & 16 & $<2$ & 62.8 & $<4$ & 1.4 & 103 \\
\hline Geometric mean & -- & -- & 16 & -- & 52.0 & - & 0.4 & 102 \\
\hline \multicolumn{9}{|c|}{ JOHN MARTIN RESERVOIR (Site R4) } \\
\hline $\begin{array}{l}\text { Double-crested } \\
\text { cormorant }\end{array}$ & $<1$ & $<1$ & 22 & $<2$ & 0.65 & $<4$ & $<0.3$ & 88.9 \\
\hline $\begin{array}{l}\text { Double-crested } \\
\text { cormorant }\end{array}$ & 1 & $<1$ & 30 & $<2$ & 0.49 & $<4$ & $<0.3$ & 105 \\
\hline $\begin{array}{l}\text { Double-crested } \\
\text { cormorant }\end{array}$ & 1 & $<1$ & 27 & $<2$ & 0.69 & $<4$ & $<0.3$ & 90.3 \\
\hline $\begin{array}{l}\text { Dourble-crested } \\
\text { cormorant }\end{array}$ & 1 & $<1$ & 29 & $<2$ & 0.69 & $<4$ & $<0.3$ & 87.0 \\
\hline $\begin{array}{l}\text { Double-crested } \\
\text { cormorant }\end{array}$ & $<1$ & $<1$ & 23 & $<2$ & 0.70 & $<4$ & $<0.3$ & 98.8 \\
\hline $\begin{array}{l}\text { Double-crested } \\
\text { cormorant }\end{array}$ & 2 & $<1$ & 18 & $<2$ & 0.63 & $<4$ & $<0.3$ & 212 \\
\hline Geometric mean & 0.9 & -- & 24 & -- & 0.64 & -- & -- & 107 \\
\hline Brewer's blackbird & $<1$ & 2 & 6.3 & $<2$ & 52.5 & $<4$ & 1.0 & 104 \\
\hline Brewer's blackbird & $<1$ & $<1$ & 5.7 & $<2$ & 21.5 & $<4$ & 0.8 & 107 \\
\hline Geometric mean & -- & 1.0 & 6.0 & -- & 33.6 & -- & 0.9 & 105 \\
\hline Brewer's blackbird & $<1$ & $<1$ & 4.2 & $<2$ & 16.3 & $<4$ & $<0.3$ & 62.3 \\
\hline Brewer's blackbird & $<1$ & $<1$ & 4.8 & $<2$ & 14.3 & $<4$ & $<0.3$ & 54.1 \\
\hline Geometric mean & -- & -- & 4.5 & -- & 15.3 & -- & -- & 58.1 \\
\hline Red-winged blackbird & $<1$ & $<1$ & 9.1 & $<2$ & 15.0 & $<4$ & $<0.3$ & 54.0 \\
\hline Red-winged blackbird & $<1$ & $<1$ & 6.7 & $<2$ & 17.3 & $<4$ & $<0.3$ & 69.3 \\
\hline Geometric mean & -- & -- & 7.8 & -- & 16.1 & -- & -- & 61.2 \\
\hline \multicolumn{9}{|c|}{ LAKE MCKINNEY (Site R5) } \\
\hline Mallard & 2 & $<1$ & 14 & $<2$ & 1.5 & $<5$ & $<0.3$ & 105 \\
\hline
\end{tabular}


Table 17.--Trace-element concentrations in composite samples of fish species and crayfish collected at selected stream sites in the study area, August 8-10, 1988

[Total length of fish in millimeters; 〈, less than; --, geometric mean not calculated]

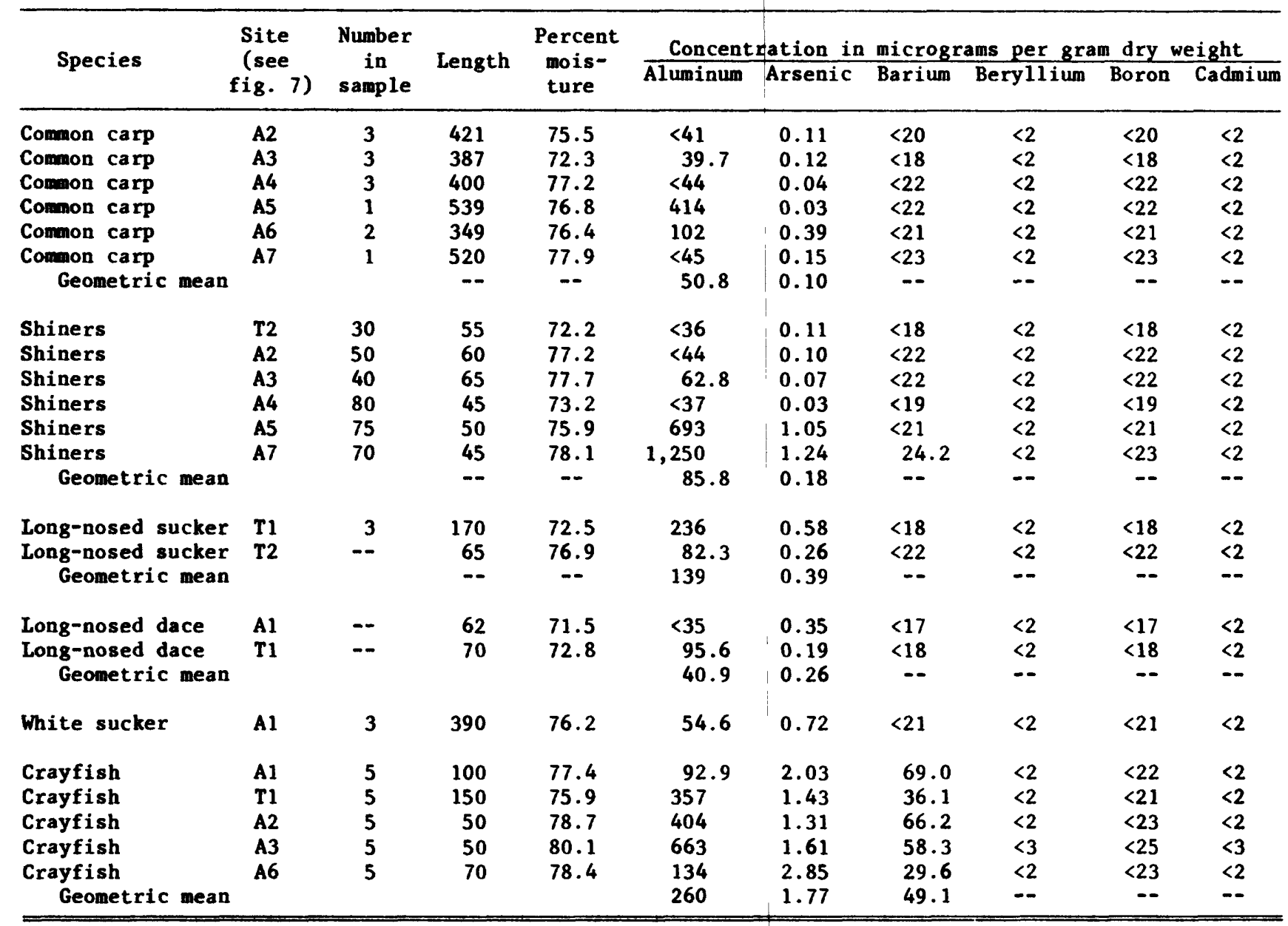

\begin{tabular}{|c|c|c|c|c|c|c|c|c|c|}
\hline \multirow{2}{*}{ Species } & \multirow{2}{*}{$\begin{array}{l}\text { Site } \\
\text { (see } \\
\text { fig. } 7 \text { ) }\end{array}$} & \multicolumn{8}{|c|}{ Concentration } \\
\hline & & Chromium & Copper & Iron & Lead & Magnesium & Manganese & Mercury & Molybdenum \\
\hline Common carp & A2 & $<4$ & 10.2 & 167 & $<11$ & 1,020 & $<6$ & 0.23 & $<20$ \\
\hline Common carp & A3 & $<4$ & $<9$ & 220 & $<36$ & 1,480 & 21.3 & 0.16 & $<18$ \\
\hline Common carp & A4 & $<4$ & $<11$ & 219 & $<44$ & 1,400 & 14.0 & 0.29 & $<22$ \\
\hline Common carp & A5 & $<4$ & $<11$ & 741 & $<43$ & 1,340 & 19.0 & 0.20 & $<22$ \\
\hline Common-carp & A6 & $<4$ & 14.8 & 479 & $<42$ & 1,740 & 33.5 & 0.80 & $<21$ \\
\hline Common carp & A7 & 13.6 & 15.4 & 290 & $<45$ & 1,580 & 8.6 & 0.43 & $<23$ \\
\hline \multicolumn{2}{|c|}{ Geometric mean } & - & 8.2 & 306 & -- & 1,410 & 13.0 & 0.30 & -- \\
\hline Shiners & T2 & $<4$ & $<9$ & 151 & $<36$ & 1,370 & 15.1 & 0.22 & $<18$ \\
\hline Shiners & A2 & $<4$ & $<11$ & 241 & $<44$ & 1,580 & 19.3 & 0.27 & $<22$ \\
\hline Shiners & $\mathbf{A 3}$ & $<4$ & $<11$ & 202 & $<45$ & 1,790 & 14.3 & 0.34 & $<22$ \\
\hline Shiners & A4 & $<4$ & $<9$ & 112 & $<37$ & 1,460 & 18.3 & 0.15 & $<19$ \\
\hline Shiners & A5 & $<4$ & $<10$ & 1,450 & $<42$ & 2,030 & 120 & 0.11 & $<21$ \\
\hline Shiners & A7 & $<5$ & $<11$ & 1,900 & $<46$ & 2,560 & 118 & 0.17 & $<23$ \\
\hline \multicolumn{2}{|l|}{ Geometric mean } & -- & -- & 362 & -- & 1,770 & 32.0 & 0.20 & -- \\
\hline \multirow{3}{*}{$\begin{array}{l}\text { Long-nosed sucker } \\
\text { Long-nosed sucker } \\
\text { Geometric mean }\end{array}$} & $\mathrm{T} 1$ & $<4$ & $<9$ & 709 & $<36$ & 1,820 & 30.9 & 0.30 & $<18$ \\
\hline & $\mathrm{T} 2$ & $<4$ & $<11$ & 532 & $<43$ & 1,690 & 38.1 & 0.24 & $<22$ \\
\hline & & -- & -- & 614 & -- & 1,750 & 34.3 & 0.27 & -- \\
\hline \multirow{3}{*}{$\begin{array}{l}\text { Long-nosed dace } \\
\text { Long-nosed dace } \\
\text { Geometric mean }\end{array}$} & A1 & 5.26 & 11.9 & 130 & $<35$ & 1,330 & 51.9 & 0.20 & $<17$ \\
\hline & T1 & & $<9$ & 368 & $<37$ & 1,540 & 24.6 & 0.42 & $<18$ \\
\hline & & 3.2 & 7.3 & 219 & -- & 1,430 & 35.7 & 0.29 & -- \\
\hline
\end{tabular}


Table 17.--Trace-element concentrations in composite samples of fish species and crayfish collected at selected stream sites in the study area, August 8-10, 1988--Continued

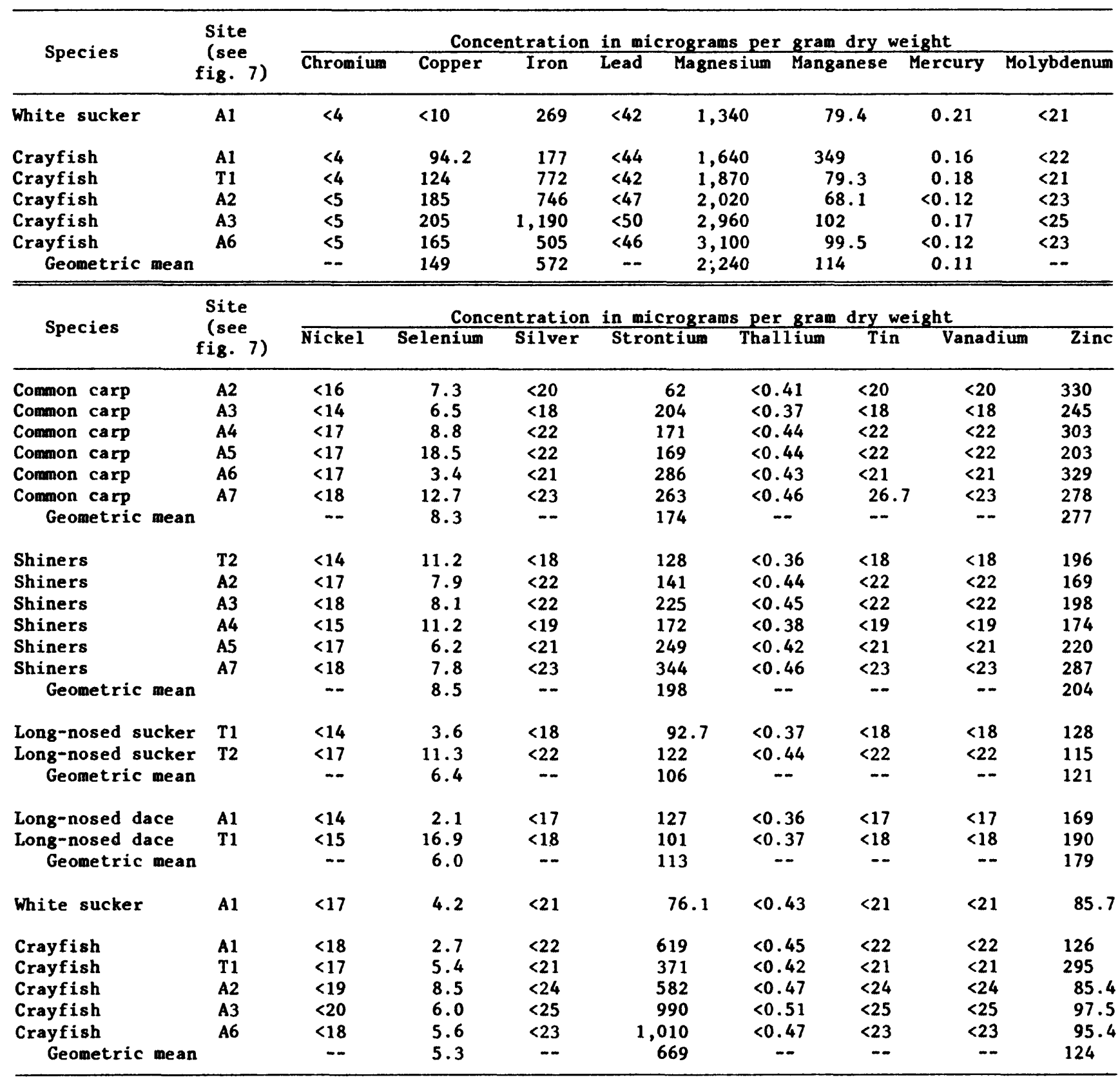


Table 18.--Trace-element concentrations in indivicual and composite samples of whole fish and invertebrates collected at reservoir sites in the study area,

June 7-10 and October 7-13, 1988

[mm, total length of fish in millimeters; --, geometric mean not calculated; NC, data not collected; 〈, less than]

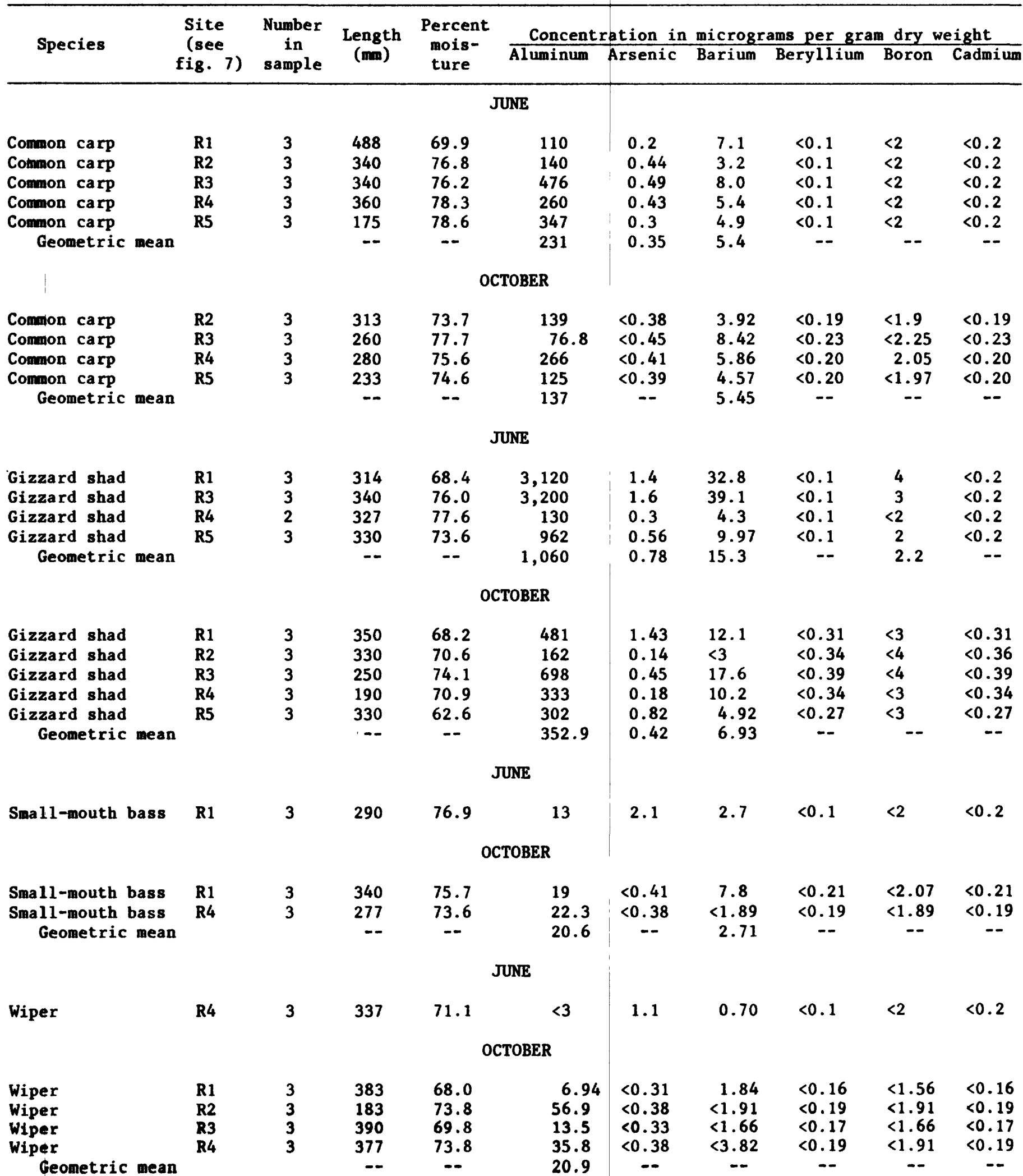


Table 18.--Trace-element concentrations in individual and composite samples of whole fish and invertebrates collected at reservoir sites in the study area, June 7-10 and October 7-13, 1988--Continued

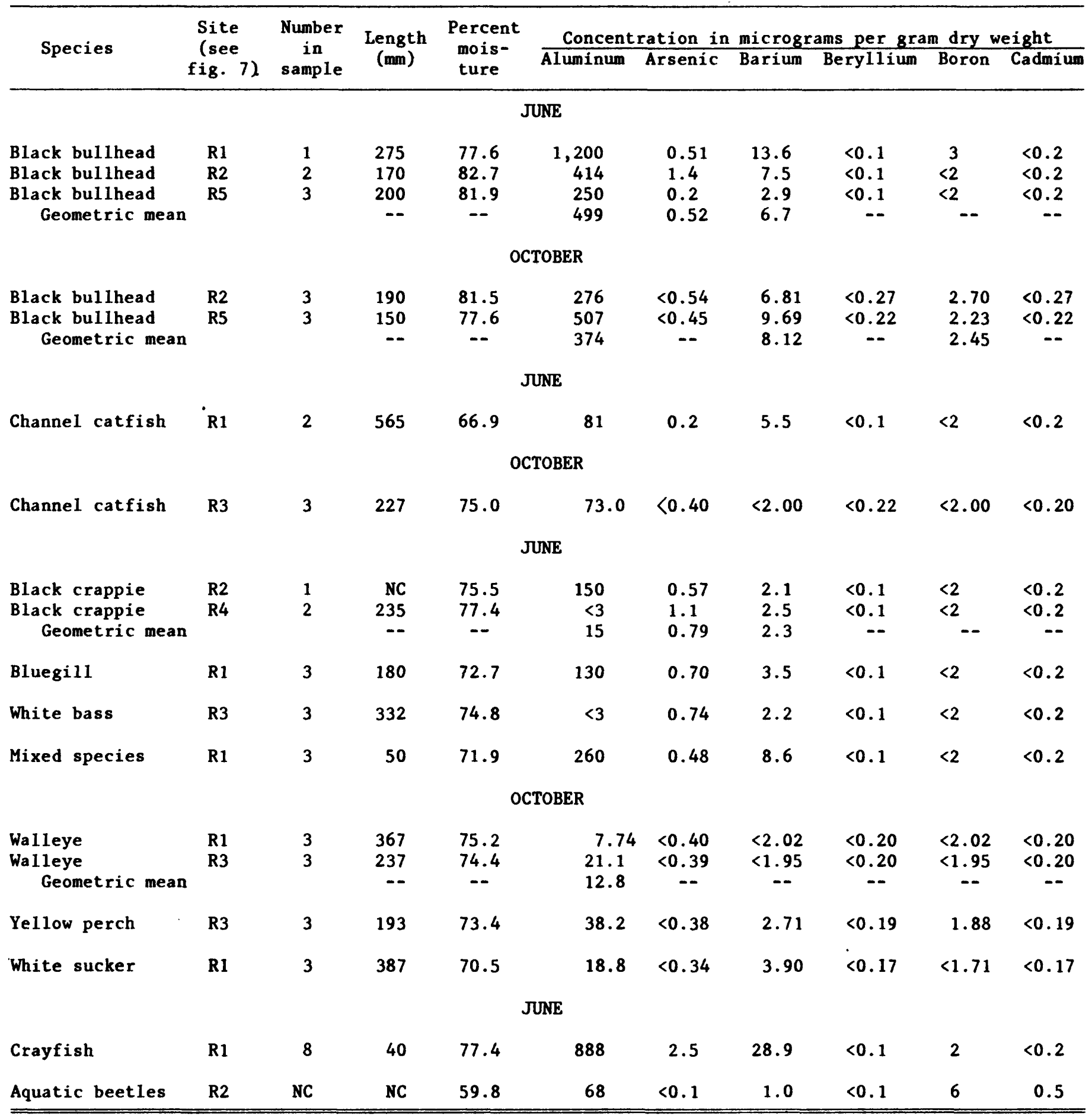


Table 18.--Trace-element concentrations in individual and composite samples of whole fish and invertebrates collected at reservoir sites in the study area,

Jume 7-10 and October 7-13, 1988--Continued

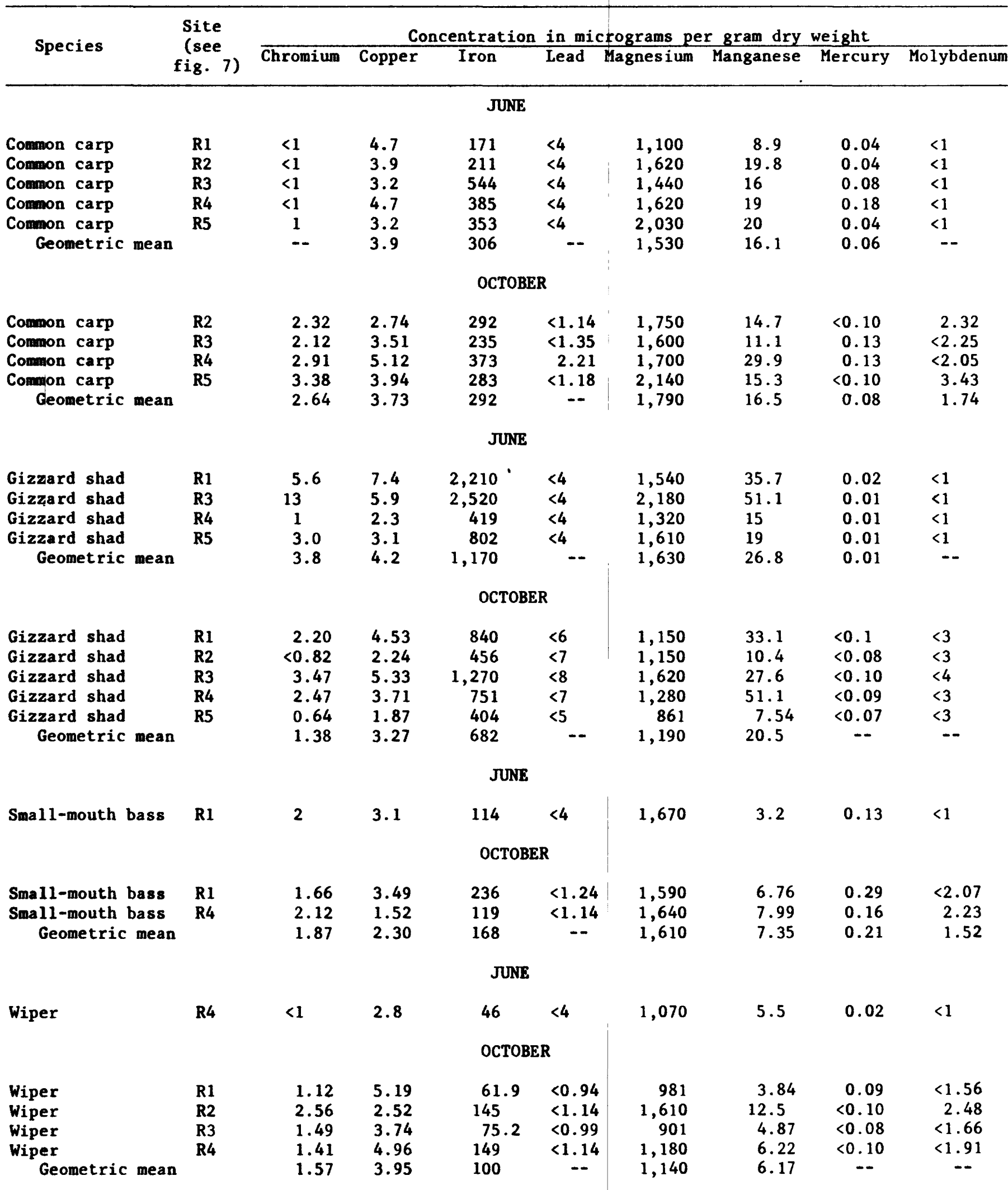


Table 18.--Trace-element concentrations in individual and composite samples of whole $f$ ish and invertebrates collected at reservoir sites in the study area, Jume 7-10 and October 7-13, 1988--Continued

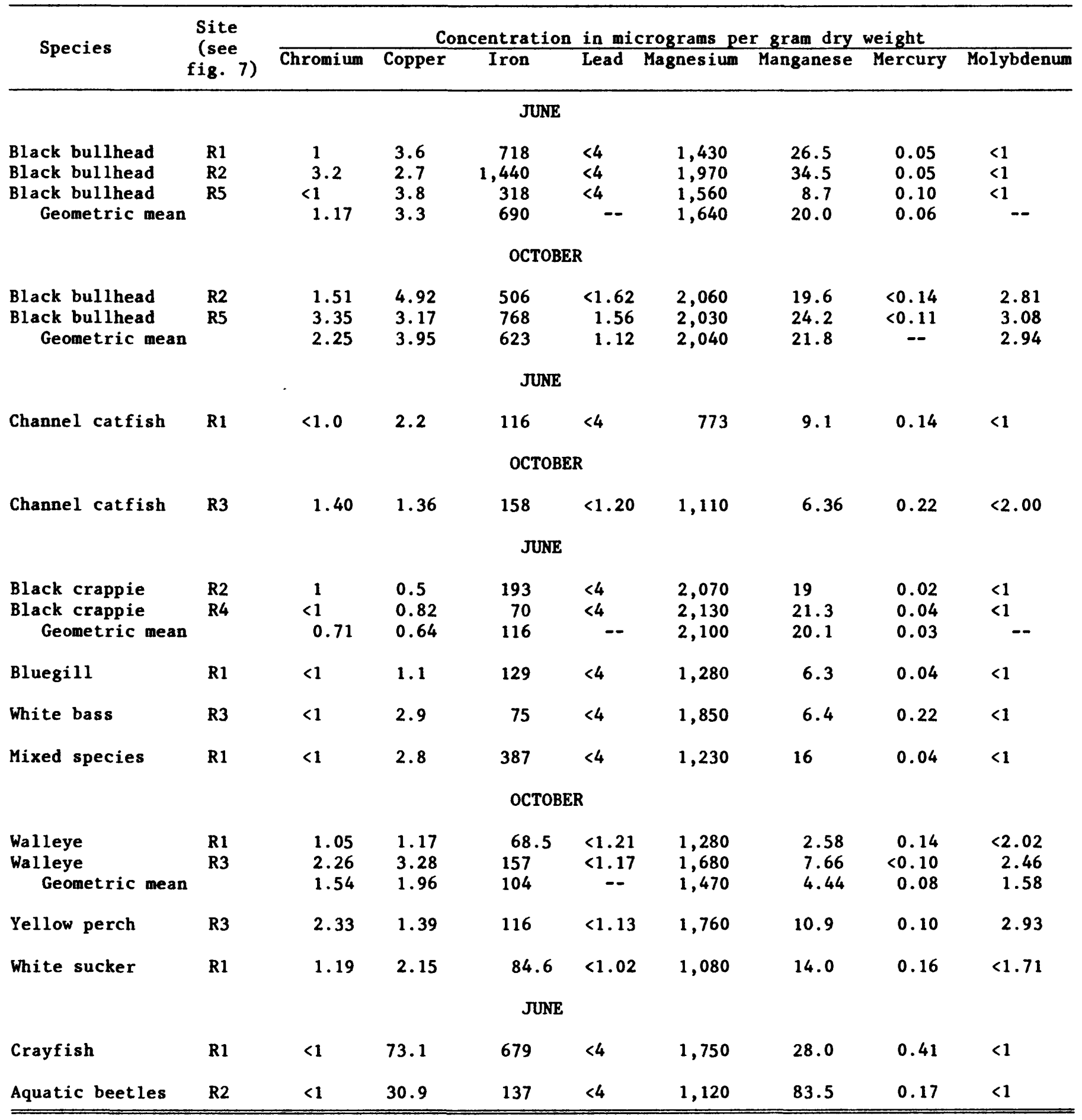


Table 18.--Trace-element concentrations in individual and composite samples of whole $f$ ish and invertebrates collected at reservoir sites in the study area, June 7-10 and October 7-13, 1988--Continued

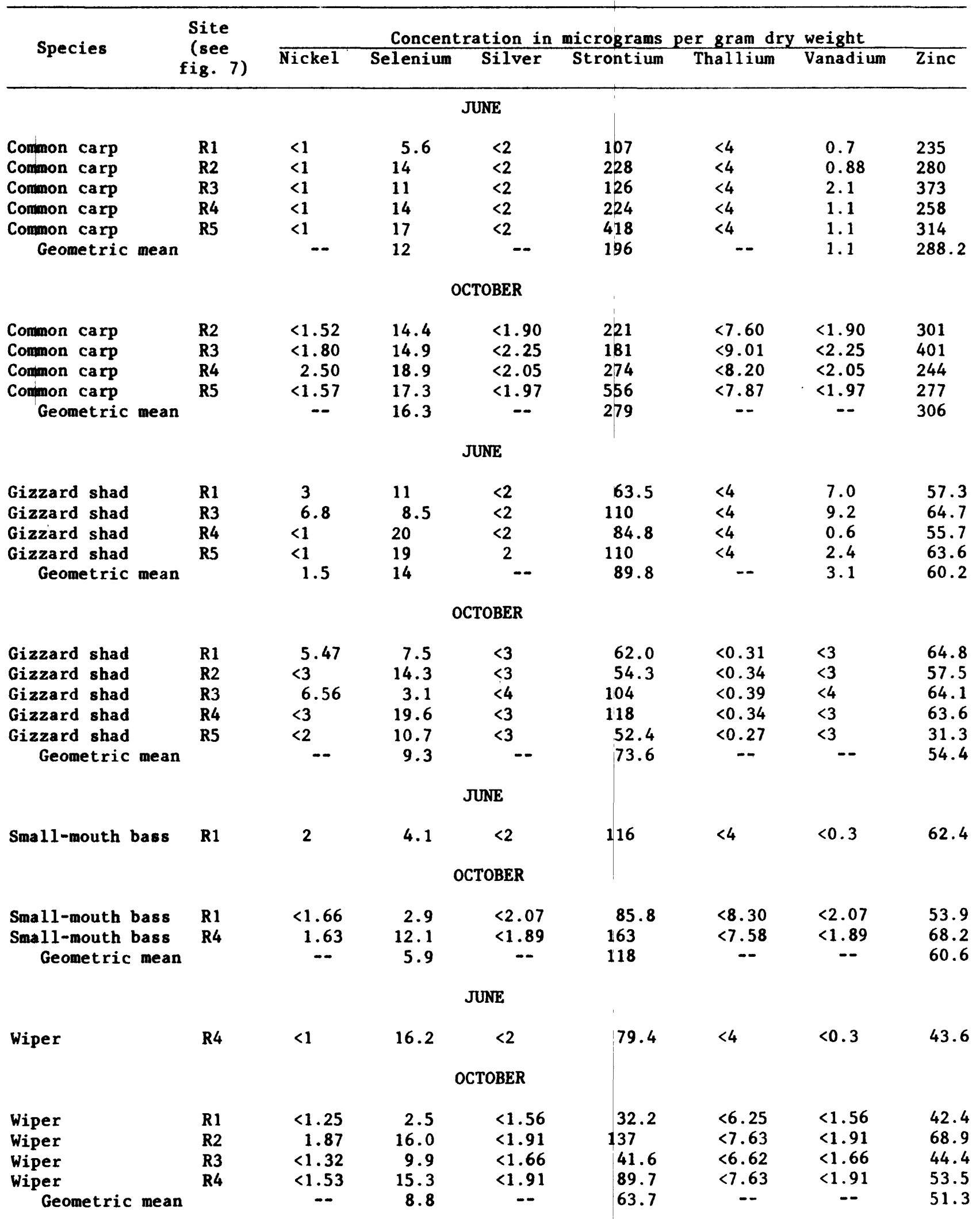


Table 18.--Trace-element concentrations in individual and composite samples of whole fish and invertebrates collected at reservoir sites in the study area,

June 7-10 and October 7-13, 1988--Continued

\begin{tabular}{|c|c|c|c|c|c|c|c|c|}
\hline \multirow{2}{*}{ Species } & \multirow{2}{*}{$\begin{array}{c}\text { Site } \\
\text { (see } \\
\text { fig. 7) }\end{array}$} & \multicolumn{7}{|c|}{ Concentration in micrograms per gram dry weight } \\
\hline & & Nickel & Selenium & Silver & Strontium & Thallium & Vanadium & $\overline{\text { Zinc }}$ \\
\hline \multicolumn{9}{|c|}{ JUNE } \\
\hline Black bullhead & R1 & $<1$ & 7.4 & $<2$ & 88.5 & $<4$ & 3.9 & 64.1 \\
\hline Black bullhead & $\mathbf{R} \mathbf{2}$ & $<1$ & 9.2 & $<2$ & 241 & $<4$ & 4.8 & 92.8 \\
\hline Black bullhead & R5 & $<1$ & 12 & $<2$ & 143 & $<4$ & 1.1 & 85.3 \\
\hline Geometric mean & & - & 9.3 & -- & 145 & -- & 2.7 & 79.8 \\
\hline \multicolumn{9}{|c|}{ OCTOBER } \\
\hline Black bullhead & $\mathbf{R} 2$ & $<2.16$ & 9.7 & $<2.70$ & 217 & $<10.8$ & $<2.70$ & 115 \\
\hline Black bullhead & R5 & $<1.79$ & 3.1 & $<2.33$ & 280 & $<8.93$ & 3.17 & 92.7 \\
\hline Geometric mean & & -- & 5.5 & -- & 246 & - & 2.07 & 103 \\
\hline \multicolumn{9}{|c|}{ JUNE } \\
\hline Channel catfish & R1 & $<1$ & 2.2 & $<2$ & 47.4 & $<4$ & 0.5 & 46.3 \\
\hline \multicolumn{9}{|c|}{ OCTOBER } \\
\hline Channel catfish & R3 & $<1.60$ & 5.2 & $<2.00$ & 83.8 & $<8.00$ & $<2.00$ & 83.8 \\
\hline \multicolumn{9}{|c|}{ JUNE } \\
\hline Black crappie & R2 & $<1$ & 13 & $<2$ & 320 & $<4$ & 0.5 & 64.7 \\
\hline Black crappie & R4 & $<1$ & 12 & $<2$ & 431 & $<4$ & $<0.3$ & 71.7 \\
\hline Geometric mean & & -- & 12 & -- & 371 & -- & 0.3 & 68.1 \\
\hline Bluegill & $\mathbf{R} 1$ & $<1$ & 5.2 & $<2$ & 80.8 & $<4$ & 0.7 & 65.0 \\
\hline White bass & R3 & $<1$ & 6.3 & $<2$ & 211 & $<4$ & $<0.3$ & 70.5 \\
\hline Mixed species & $\mathbf{R} \mathbf{1}$ & $<1$ & 6.4 & $<2$ & 92.1 & $<4$ & 1.1 & 93.6 \\
\hline \multicolumn{9}{|c|}{ OCTOBER } \\
\hline Walleye & R1 & $<1.61$ & 2.4 & $<2.02$ & 21.8 & $<8.06$ & $<2.02$ & 40.1 \\
\hline Walleye & R3 & 3.01 & 5.5 & $<1.95$ & 80.1 & $<7.81$ & $<1.95$ & 57 \\
\hline Geometric mean & & 1.98 & 3.6 & -- & 41.8 & -- & -- & 47.8 \\
\hline Yellow perch & R3 & $<1.50$ & 11.3 & $<1.88$ & 123 & $<7.52$ & $<1.88$ & 123 \\
\hline White sucker & R1 & $<1.37$ & 3.4 & $<1.71$ & 44.0 & $<6.83$ & $<1.71$ & 42.8 \\
\hline \multicolumn{9}{|c|}{ JUNE } \\
\hline Crayfish & RI & $<1$ & 8.7 & $<2$ & 644 & $<4$ & 2.6 & 60.9 \\
\hline Aquatic beetles & $\mathbf{R} 2$ & $<1$ & 6.4 & $<2$ & 17.3 & $<4$ & $<0.3$ & 158 \\
\hline
\end{tabular}


Table 19.--Trace-element concentrations in composite samples of aquatic plant species collected at selected reservoir sites in the study area, June 7-10, 1988

[A11 algae samples are a composite of many whole plants; pondweed samples are a composite of plant tops only; sampling sites are shown in figure 7; letters denote subsamples from the same reservoir; <, less than]

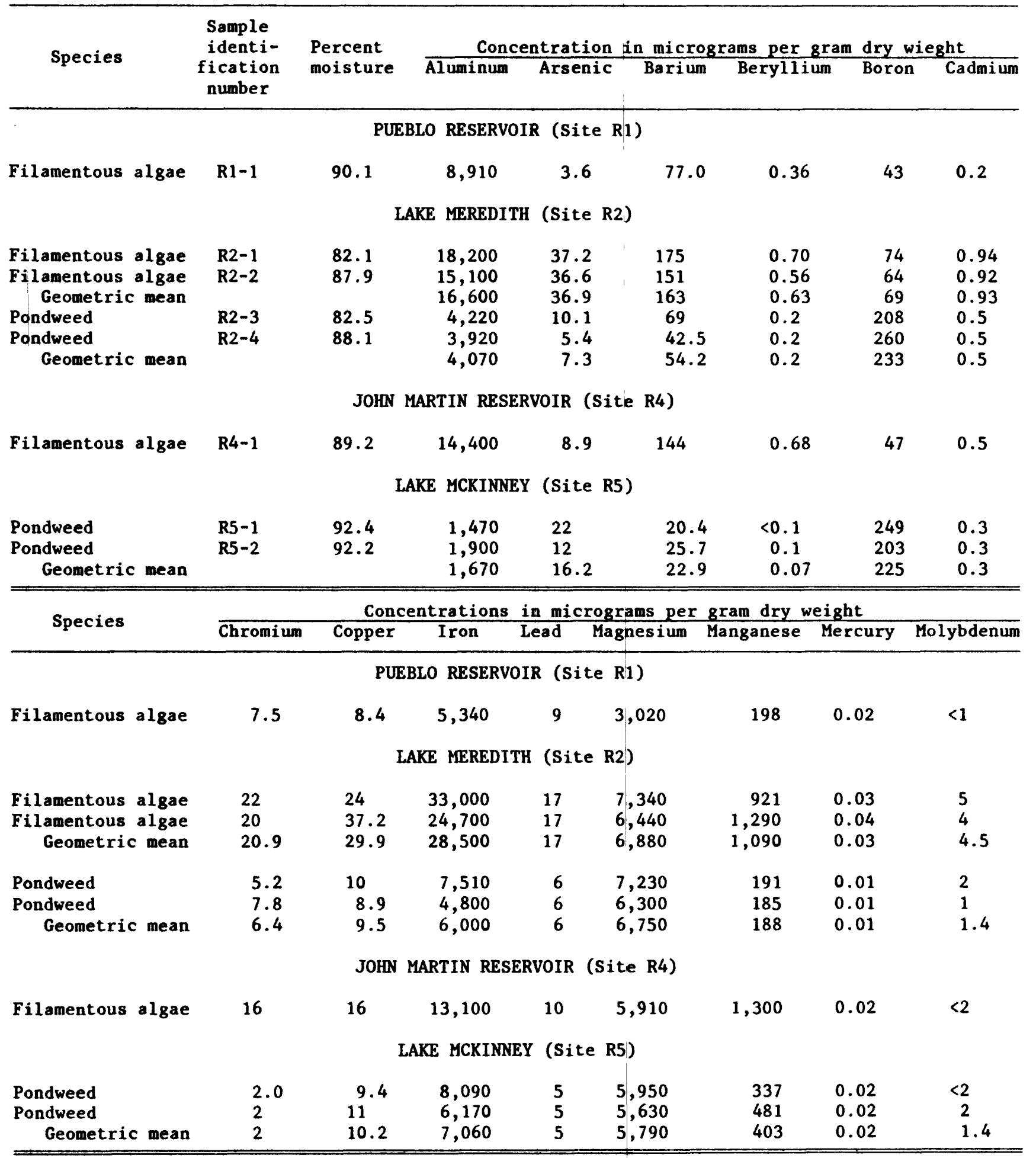


Table 19.--Trace-element concentrations in composite samples of aquatic plant species collected at selected reservoir sites in the study area, June 7-10, 1988--Continued

\begin{tabular}{|c|c|c|c|c|c|c|c|}
\hline \multirow{2}{*}{ Species } & \multicolumn{7}{|c|}{ Concentrations in micrograms per gram dry weight } \\
\hline & Nickel & Selenium & Silver & Strontium & Thallium & Vanadium & $\overline{\text { Zinc }}$ \\
\hline \multicolumn{8}{|c|}{ PUEBLO RESERVOIR (Site R1) } \\
\hline Filamentous algae & 9.0 & 3.2 & $<2$ & 525 & $<4$ & 21 & 38.3 \\
\hline \multicolumn{8}{|c|}{ LAKE MEREDITH (Site R2) } \\
\hline Filamentous algae & 22 & 14 & $<2$ & 442 & $<4$ & 74.4 & 71.2 \\
\hline Filamentous algae & 26 & 7.2 & $<2$ & 309 & $<4$ & 59.3 & 66.3 \\
\hline Geometric mean & 23.9 & 10 & -- & 370 & -- & 66.4 & 68.7 \\
\hline Pondweed & 7.2 & 4.2 & $<2$ & 330 & $<4$ & 20 & 36.6 \\
\hline Pondweed & 7.9 & 6.0 & $<2$ & 336 & $<4$ & 15 & 31.0 \\
\hline Geometric mean & 7.5 & 5.0 & -- & 333 & -- & 17 & 33.7 \\
\hline \multicolumn{8}{|c|}{ JOHN MARTIN RESERVOIR (Site R4) } \\
\hline Filamentous algae & 16 & 5.6 & $<2$ & 320 & $<4$ & 31 & 54.1 \\
\hline \multicolumn{8}{|c|}{ LAKE MCKINNEY (Site R5) } \\
\hline Pondweed & 7.1 & 4.5 & $<2$ & 308 & $<4$ & 7.9 & 43.8 \\
\hline Pondweed & 6.5 & 5.4 & $<2$ & 268 & $<4$ & 8.1 & 47.0 \\
\hline Geometric mean & 6.8 & 4.9 & -- & 287 & -- & 8.0 & 45.4 \\
\hline
\end{tabular}


Tạble 20.--Concentrations of organochlorine pesticides in livers and eggs of birds and composite samples of fish collected at selected reservoir sites in the study area, June 7-10, 1988

[Except where indicated, all concentrations are in $\mu \mathrm{g} / \mathrm{g}$ wet weight; avian samples are liver except for black-crowned night heron eggs; sampling sites are shown in figure 7; B-BHC, beta benzenehexachloride; OXY, oxychlordane; HEP, heptachlorepoxide; TRANS-NON, trans-nonachlor; $D D E=p, p^{\prime}-D D E ; D I E L D=d i e 1 d r i n$; $\left.\mathrm{DDD}=\mathrm{p}, \mathrm{p}^{\prime}-\mathrm{DDD} ; \mathrm{DDT}=\mathrm{p}, \mathrm{p}^{\prime}-\mathrm{DDT}\right]$

\begin{tabular}{|c|c|c|c|c|c|c|c|c|c|c|c|}
\hline \multirow{2}{*}{$\begin{array}{l}\text { Sample } \\
\text { type }\end{array}$} & \multirow{2}{*}{$\begin{array}{l}\text { Number } \\
\text { in } \\
\text { sample }\end{array}$} & \multicolumn{2}{|c|}{ Percent } & \multicolumn{8}{|c|}{ Organochlorine compound } \\
\hline & & $\frac{\text { Lipids }}{\text { Lip }}$ & Moisture & B-BHC & OXY & HEP & $\begin{array}{l}\text { TRANS- } \\
\text { NON }\end{array}$ & DDE & DIELD & DDD & DDT \\
\hline \multicolumn{12}{|c|}{ Site R1 } \\
\hline $\begin{array}{l}\text { Mallard liver } \\
\text { Mallard liver } \\
\text { Killdeer liver } \\
\text { Killdeer liver } \\
\text { Common carp } \\
\text { Gizzard shad }\end{array}$ & $\begin{array}{l}1 \\
1 \\
3 \\
3 \\
3 \\
3\end{array}$ & $\begin{array}{l}6.59 \\
5.67 \\
4.10 \\
6.22 \\
12.0 \\
11.1\end{array}$ & $\begin{array}{l}69.6 \\
66.0 \\
69.3 \\
66.3 \\
69.6 \\
68.0\end{array}$ & $\begin{array}{l}<0.01 \\
<0.01 \\
<0.01 \\
<0.01 \\
<0.01 \\
<0.01\end{array}$ & $\begin{array}{r}<0.01 \\
<0.01 \\
0.02 \\
0.02 \\
<0.01 \\
<0.01\end{array}$ & $\begin{array}{r}<0.01 \\
<0.01 \\
0.01 \\
0.09 \\
<0.01 \\
<0.01\end{array}$ & $\begin{array}{r}<0.01 \\
<0.01 \\
<0.01 \\
0.01 \\
0.01 \\
0.01\end{array}$ & $\begin{array}{l}<0.01 \\
0.05 \\
0.22 \\
1.0 \\
0.05 \\
0.04\end{array}$ & $\begin{aligned}<0.01 \\
<0.01 \\
0.02 \\
0.13 \\
<0.01 \\
<0.01\end{aligned}$ & $\begin{aligned}<0.01 \\
<0.01 \\
<0.01 \\
<0.01 \\
0.01 \\
0.01\end{aligned}$ & $\begin{array}{l}<0.01 \\
<0.01 \\
<0.01 \\
<0.01 \\
<0.01 \\
<0.01\end{array}$ \\
\hline \multicolumn{12}{|c|}{ Site R2 } \\
\hline $\begin{array}{l}\text { Mallard liver } \\
\text { Mallard liver } \\
\text { Killdeer liver } \\
\text { Killdeer liver } \\
\text { Black-crowned } \\
\text { night heron egg }\end{array}$ & $\begin{array}{l}1 \\
1 \\
3 \\
3 \\
1\end{array}$ & $\begin{array}{l}2.17 \\
2.96 \\
5.73 \\
4.70 \\
7.27\end{array}$ & $\begin{array}{l}72.8 \\
69.4 \\
70.3 \\
68.4 \\
79.0\end{array}$ & $\begin{array}{l}<0.01 \\
<0.01 \\
<0.01 \\
<0.01 \\
<0.01\end{array}$ & $\begin{array}{r}<0.01 \\
0.01 \\
0.02 \\
0.10 \\
<0.01\end{array}$ & $\begin{array}{r}<0.01 \\
<0.01 \\
0.03 \\
0.13 \\
<0.01\end{array}$ & $\begin{array}{r}<0.01 \\
<0.01 \\
<0.01 \\
0.01 \\
<0.01\end{array}$ & $\begin{array}{r}<0.01 \\
0.02 \\
0.36 \\
0.23 \\
0.15\end{array}$ & $\begin{array}{r}<0.01 \\
<0.01 \\
0.03 \\
0.03 \\
<0.01\end{array}$ & $\begin{array}{l}<0.01 \\
<0.01 \\
<0.01 \\
<0.1 \\
<0.01\end{array}$ & $\begin{array}{l}<0.01 \\
<0.01 \\
<0.01 \\
<0.01 \\
<0.01\end{array}$ \\
\hline $\begin{array}{l}\text { Black-crowned } \\
\text { night heron egg }\end{array}$ & 1 & 6.74 & 82.0 & 0.01 & te $R 4$ & $0 ! .03$ & 0.01 & 0.50 & 0.18 & $<0.01$ & 0.05 \\
\hline $\begin{array}{l}\text { Killdeer liver } \\
\text { Killdeer liver } \\
\text { Double-crested } \\
\text { cormorant liver }\end{array}$ & $\begin{array}{r}3 \\
3 \\
1\end{array}$ & $\begin{array}{l}5.18 \\
9.20 \\
2.73\end{array}$ & $\begin{array}{l}69.1 \\
68.5 \\
76.0\end{array}$ & $\begin{array}{r}0.04 \\
<0.01 \\
<0.01\end{array}$ & $\begin{array}{r}0.05 \\
0.02 \\
<0.01\end{array}$ & $\begin{array}{r}0.06 \\
0.05 \\
<0.01\end{array}$ & $\begin{array}{r}0.02 \\
<0.01 \\
<0.01\end{array}$ & $\begin{array}{l}2.3 \\
1.3 \\
0.04\end{array}$ & $\begin{array}{l}0.04 \\
0.07 \\
0.01\end{array}$ & $\begin{array}{l}<0.01 \\
<0.01 \\
<0.01\end{array}$ & $\begin{array}{l}<0.01 \\
<0.01 \\
<0.01\end{array}$ \\
\hline $\begin{array}{l}\text { Double-crested } \\
\text { cormorant liver }\end{array}$ & 1 & 2.75 & 73.0 & $<0.01$ & $\begin{array}{l}<0.01 \\
\text { te } R 5\end{array}$ & $<0.01$ & $<0.01$ & 0.02 & $<0.01$ & $<0.01$ & $<0.01$ \\
\hline $\begin{array}{l}\text { Mallard liver } \\
\text { Mallard liver } \\
\text { Killdeer liver } \\
\text { Killdeer liver } \\
\text { Common carp } \\
\text { Gizzard shad }\end{array}$ & $\begin{array}{l}1 \\
1 \\
3 \\
3 \\
3 \\
3\end{array}$ & $\begin{array}{l}1.88 \\
4.30 \\
3.80 \\
4.31 \\
1.97 \\
5.62\end{array}$ & $\begin{array}{l}69.5 \\
71.0 \\
71.8 \\
70.0 \\
78.0 \\
72.0\end{array}$ & $\begin{array}{l}<0.01 \\
<0.01 \\
<0.01 \\
<0.01 \\
<0.01 \\
<0.01\end{array}$ & $\begin{array}{r}0.01 \\
<0.01 \\
0.01 \\
0.04 \\
<0.01 \\
<0.01\end{array}$ & $\begin{array}{r}0.04 \\
0.01 \\
0.04 \\
0.07 \\
<0.01 \\
<0.01\end{array}$ & $\begin{array}{r}<0.01 \\
<0.01 \\
<0.01 \\
<0.01 \\
<0.01 \\
0.01\end{array}$ & $\begin{array}{l}0.02 \\
0.04 \\
0.04 \\
0.37 \\
0.01 \\
0.02\end{array}$ & $\begin{array}{r}<0.01 \\
0.26 \\
0.02 \\
0.07 \\
<0.01 \\
0.01\end{array}$ & $\begin{array}{l}<0.01 \\
<0.01 \\
<0.01 \\
<0.01 \\
<0.01 \\
<0.01\end{array}$ & $\begin{array}{l}<0.01 \\
<0.01 \\
<0.01 \\
<0.01 \\
<0.01 \\
<0.01\end{array}$ \\
\hline
\end{tabular}

